\title{
Evaluation of Geologic Materials to Limit Biological Intrusion into Low-Level Radioactive Waste Disposal Sites
}

\author{
T. E. Hakonson
}

\section{DISCLAIMER}

This report was prepared as an account of work sponsored by an agency of the United States Government. Neither the United States Government nor any agency thereof, nor any of their employees, makes any warranty, express or implied, or assumes any legal liability or responsibility for the accuracy, completeness, or usefulness of any information, apparatus, product, or process disclosed, or represents that its use would not infringe privately owned rights. Reference herein to any specific commercial product, process, or service by trade name, trademark, manufacturer, or otherwise does not necessarily constitute or imply its endorsement, recommendation, or favoring by the United States Government or any agency thereof. The views and opinions of authors expressed herein do not necessarily state or reflect those of the United States Government or any agency thereof.
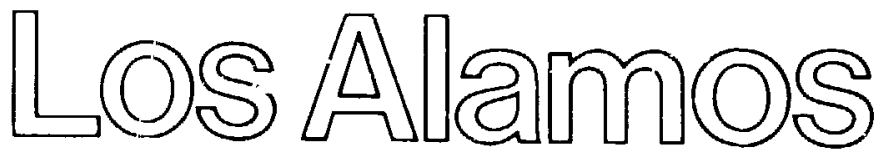

Lus Alamos National Laboratory Los Alamos,New Mexico 87545 
TABLE C-I

CESIUM CONCENTRATIONS IN VEGETATION SAMPLES FROM A CONVENTIONAL AND MODIFIED TRENCH CAP DESIGN AT AREA B

\begin{tabular}{|c|c|c|c|c|c|c|c|c|}
\hline \multirow[b]{3}{*}{ Date } & \multicolumn{8}{|c|}{ Cap Design } \\
\hline & \multicolumn{4}{|c|}{ Soil-Cobble/Gravel } & \multicolumn{4}{|c|}{ Soil-Crushed Tuff } \\
\hline & 11 & 2 & 3 & 4 & 1 & 2 & 3 & 4 \\
\hline June 21,1983 & 0.03 & 0.04 & 0.01 & 0.03 & 0.04 & 0.06 & 0.06 & 0.05 \\
\hline \multirow[t]{2}{*}{ July 21,1983} & 0.13 & 0.27 & 0.13 & 0.09 & 0.31 & 0.49 & 0.20 & 0.15 \\
\hline & 0.24 & 0.24 & 0.13 & 0.21 & 0.53 & 0.13 & 0.08 & 0.05 \\
\hline August 29,1983 & 0.26 & 0.31 & 0.25 & 0.27 & 0.46 & 0.34 & 0.15 & $2.1^{k}$ \\
\hline October 4. 1983 & 0.18 & 0.14 & 0.15 & 0.26 & 0.78 & 0.09 & 0.30 & 0.10 \\
\hline November 8,1983 & 0.24 & 0.26 & 0.16 & 0.18 & 0.18 & 0.22 & 0.09 & 0.08 \\
\hline
\end{tabular}

a Sample number.

${ }^{b}$ Exceeds background concentrations of $\leq 1 \mathrm{ppm}$. 
FIGURES $\ldots \ldots \ldots \ldots \ldots \ldots \ldots \ldots \ldots \ldots \ldots \ldots \ldots \ldots \ldots \ldots \ldots \ldots v i$

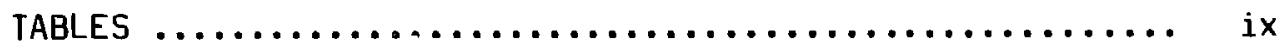

ABSTRACT ............................... 1

1. INTRODUCTION ........................ 3

1.1 Purpose and Scope of Report .................. 3

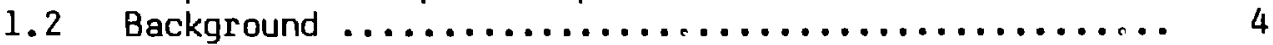

1.3 Approaches To Limit Biointrusion ............... 10

2. FIELD EXPERIMENTS $\ldots \ldots \ldots \ldots \ldots \ldots \ldots \ldots \ldots \ldots \ldots \ldots \ldots \ldots . \ldots \ldots$

2.1 Experimental Approach ...................... 12

2.2 Small Scale Biointrusion Barrier Studies ........... 13

A. Methods and Materials ................... 13

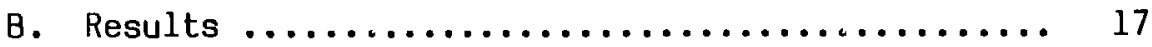

2.3 Intermediate Scale Biointrusion Barrier Studies ..... 26

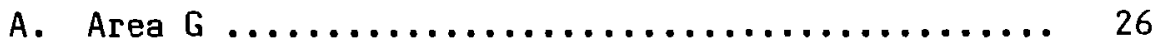

1. Methods and Materials ................. 26

2. Results ........................... 30

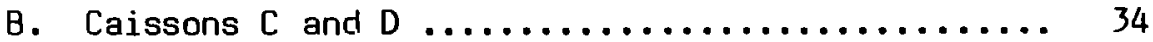

1. Methods and Materials .................. 34

2. Results ........................... 38

2.4 Field Scale Studies - Area $8 \ldots \ldots \ldots \ldots \ldots \ldots \ldots \ldots \ldots \ldots . . . . . . \ldots 9$

A. Methods and Materials .................... 49

B. Results .......................... 53

3. DISCUSSION ............................ 59

3.1 Interpretation of Experimental Data ............ 59

3.2 Limitations/Research Needs .................... 66

3.3 Implications For Waste Site Operations ........... 69

4. ACKNOWLEDGMENTS $\ldots \ldots \ldots \ldots \ldots \ldots \ldots \ldots \ldots \ldots \ldots \ldots \ldots$

REFERENCES $\ldots \ldots \ldots \ldots \ldots \ldots \ldots \ldots \ldots \ldots \ldots \ldots \ldots \ldots \ldots \ldots \ldots \ldots$

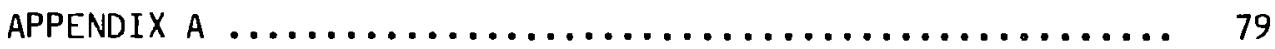

APPENDIX $8 \ldots \ldots \ldots \ldots \ldots \ldots \ldots \ldots \ldots \ldots \ldots \ldots \ldots \ldots \ldots \ldots \ldots \ldots$

APPENDIX $\mathrm{C} \ldots \ldots \ldots \ldots \ldots \ldots \ldots \ldots \ldots \ldots \ldots \ldots \ldots \ldots \ldots$ 


\section{FIGURES}

1. Hydrologic and biological processes affecting

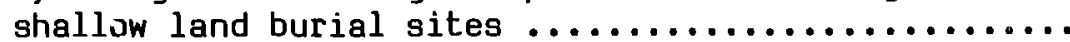

2. Transport pathways for plutonium and other radionuclides deposited in the soil compartment of terrestrial ecosystems. Physical transport of soil particles with subsequent deoosition on biological surfaces dominates in the transport of many soil contaminants to biota .................

3. Small scale biointrusion study plot showing $25 \mathrm{~cm}$ diameter lysimeter placement in casings and metal culverts in background used for the animal intrusion experiment

4. Experimental soil profile configuration used to evaluate geologic materials as root intrusion

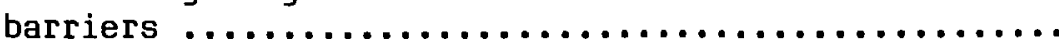

5. Root penetration into a topsoil-gravel/cobble intrusion barries cap design. Effect of cobble in inhibiting root penetration is apperent

6. Shrinking of bentonite clay intrusion barrier 90 days after seeding the lysimeters; erfect caused by plant transpiration. Note that clay shrinkage occurs in the presence of water ponded on the surface of the clay .........................

7. Clay barrier showing extreme shrinkage and drying 180 days after seeding the lysimeters. Moisture loss from clay was due to plant transpiration ........

8. Polyurethane foam cast of excavated pocket gopher burrow system showing that intrusion was inhibited at the topsoil and gravel interface ..............

9. Polyurethane foam cast of pocket gopher tunnel system showing intrusion through topsoil into crushed tuff barrier material. Also note light circular tuff material blocking old tunnel in topsoil, showing that materials are displaced vertically within the soil profile by burrowing animals

10. Intermediate scale biointrusion barrier experiment at Area $G$ 
11. Four biointrusion barrier plots under construction on trench 25 at Area $G$ in 1981. Galvanized metal plot borders, neutron acces tubes, and portions of the barrier materials are shown just prior to adding

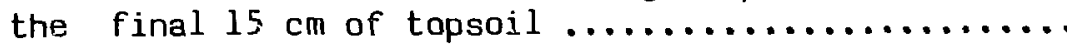

12. Volumetric water content of backfill under the biointrusion barrier cap designs at Area $G$..........

13. Daily precipitation and snow cover on the Area G biointrusion barrier study plots ...............

14. Design of intermediate scale biointrusion study conducted in $3 \times 6 \mathrm{~m}$ caiss $n$ ns at the Los Alamos Experimental Engineered Test Facility .............

15. Caisson $C$ (foreground) and D (background) used in biointrusion barrier study. Neutron access tubes and alfalfa cover shown on the surface of the caissons

16. Predicted average annual hydraulic values as a function of trench cap thickness at Los Alamos. Calculations based on a clay loam Hackroy series topsoil and a 20 year (1951-1970) precipitation record at Los Alamos, New Mexico .................

17. Volumetric water content of the $60 \mathrm{~cm}$ topsoil layer ccvering the biointrusion barriers in

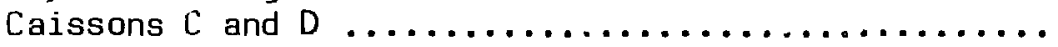

18. Volumetric water content of the crushed tuff backfill under the biointrusion barriers in

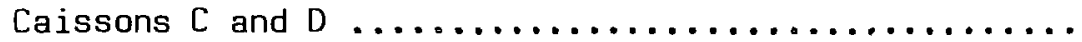

19. Daily presipitation and snow cover on the Caisson $C$ and $D$ biointrusion barrier study plots ..........

20. Area B low-level waste site (fenced area) prior to removal of tree and shrub cover. Area $B$ was decommissioned in 1947 and received a new caver in 1982

21. Schematic of plot configurations for the Area $B$ biointrusion barrier study initiated in 1982.

Control treatment represented the conventional cap design constructed on Area B. The intrusion barrier design consisted of topsoil over layered

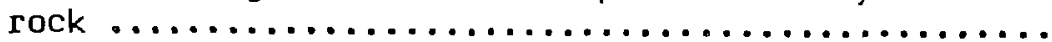


22. Construction of biointrusion barrier plots at Area $B$ in 1982. The cobble/gravel barrier design is shown under construction in the center of the photo. The conventionl cap design plot was located in the background under the stockpiled topsoil

23. Application of cesium chloride to old trench cap surface at Area $B$ to serve as a simulated waste for evaluating plant root intrusion through the new trench cap designs

24. Construction of layered cobble and gravel intrusion barrier cap designs on Area $B$ in 1982

25. Wheat cover on Area B biointrusion barrier study plots during 1983. Some grass cover did become established in 1983 and dominated the cover in 1984

26. Volumetric water content of the topsoil covering the biointrusion barriers used at Area B .......... 56

27. Volumetric water content of backfill $30 \mathrm{~cm}$ under

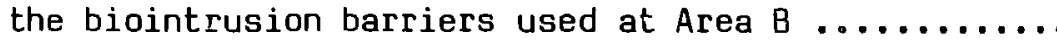

28. Daily precipitation and snow cover during the

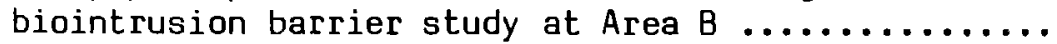


TABLES

I. Experimental design of small scale plarit root

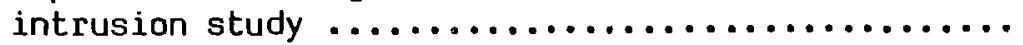

II. Relationships of barrier penetrations to plant species, barrier material, and time post-seeding ...

III. Number of root penetrations through crushed tuff as a function of cap depth and time post-seeding ...

IV. Number of root penetrations through bentonite clay as a function of cap depth and time postseeding

V. Number of root penetrations through cobble as a function of cap depth and tine post-seeding

VI. Number of root penetrations ihrough cobble/gravel as a function of cap cepth and time post-seeding ...

VII. Grass species and seed application rates used ir. revegetating the Area $G$ intermediate-scale biointrusion barrier study ...................

VIII. Average $(n=4)$ cesium concentrations (ppm) in vegetation growing on Area $G$ biointrusion

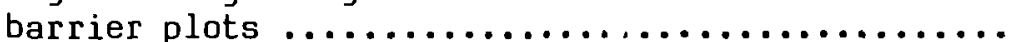

IX. Cesium concentrations averaged across all sampling dates for the four biological intrusion barrier

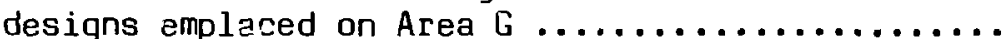

X. Monthly precipitation totals $(\mathrm{cm})$ for the Area G intermediate-scale biointrusion study ............

XI. Average ( $n=4)$ cesium concentrations and standard deviations (ppm) in vegetation from Caisson $C$ (topsoil-crushed tuff) and Caisson D (topsoilgravel/cobble) trench cover intrusion barrier

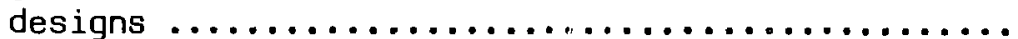

XII. Average cesium concentrations in vegetatjon samples from conventional and rock intrusion barrier trench

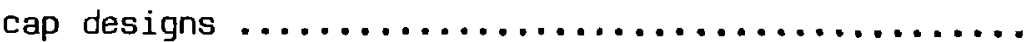

XII. Cost of applying layered rock biointrusion barriers in waste site covers in 1983 
Table A-I. Cesium concentrations (ppm) in individual plant samples from the $15 \mathrm{~cm}$ topsoil over $30 \mathrm{~cm}$ gravel over $70 \mathrm{~cm}$ cobble biointrusion barrier trench cap design at Area G .........

Table A-II. Cesium ccncentrations (ppm) in individual plant samples from the $15 \mathrm{~cm}$ topsoil over $100 \mathrm{~cm}$ crushed tuff bivintrusion barrier

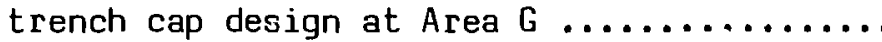

Table A-III. Cesium concentrations (ppm) in individual plant samples from the $15 \mathrm{~cm}$ topsoil over $100 \mathrm{~cm}$ cobble biuintrusion barrier trench

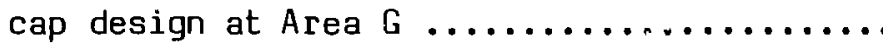

Table A-IV. Cesium concentrations (ppmi) in individual plant samples from the $15 \mathrm{~cm}$ topsoil over $15 \mathrm{~cm}$ gravel over $85 \mathrm{~cm}$ cobble biointrusion barrier trench cap design at Area G .........

Table B-I. Cesium concentrations in vegetation samples from Caisson C (topsoil-crushed tuff) and Caisson D (topsoil-gravel/cobble) trench cover intrusion barrrier designs ..........

Table B-II. Precipitation frequency estimates for Los Alamos, New Mexico ................

Table C-I. Cesium concentrations in vegetation samples from a conventional and modified cap design at Area $B \ldots \ldots \ldots \ldots \ldots \ldots \ldots \ldots \ldots . . \ldots 1$ 
EVALUATION OF GEOLOGIC MATERIALS TO LIMIT BIOL.OGICAL INTRUSION INTO LOW-LEVEL RADIOACTIVE WASTE DISPOSAL SITES

by

T. E. Hakonson

ABSTRACT

This report describes the results of a three-year research program to evaluate the performance of selected soil and rock trench cap designs in limiting biological intrusion into simulated waste. The report is divided into three sections including a discussion of backround material on biological interactions with waste site trench caps, a presentation of experimental data from field studies conducted at several scales, and a final section on the interpretation and limitations of the data including implications for the user.

In the first section the fact is established that the importance of biological processes, including plant root intrusion and animal burrowing, in contributing to radionuclide transport at low-level waste sites, cannot be dismissed out of hand. In fact, model simulations by others suggest that biological processes may contribute significantly to dose-to-man compared to other transport pathways including percolation of leachates to groundwater. Despite emerging data on the relative importance of biological processes on waste site integrity, this report is not intended as an endorsement for or against the use of biointrusion barriers in trench cap designs. Rather, experimental eviderce is presented and interpreted on barrier performance as a function of experimental scale, configuration, and a variety of extreme moisture conditions to identify operational limits should the use of a biointrusion barrier be deemed necessary.

Resulty of stufies at several scales, ranging from 25-cm-diameter columns to 1560-m field plots, demonstrated that a minimum of $75 \mathrm{~cm}$ of cobble covered with $25 \mathrm{~cm}$ gravel all covered with $60 \mathrm{~cm}$ of topsoil reduces plant root and animal intrusion through the cap profile over a conventional design constructed of soil over crushed tuff. Plant root intrusion for the soil and rock cap designs was reduced by a factor of two to eight as evaluated by a simulated cesium waste. The field scale study, which was the final test of an 
optimized soil/rock cap design for Los Alamos conditions, revealed that both the conventional and soil/rock cap desigr. were preventing root intrusion after one growing season. Unfortunately, the termination of the experiment precluded obtaining longer term data vital for a more rigorous evaluation of field performance.

An added benefit of using a soil/rock trench cap design is the reduction of percolation afforded by the capillary barrier inherent in the cap design. Water percolating through the topsoil is impeded at the soil/rock interface due to the differences in hydraulic conductivities of the two materials. Only when the topsoil becomes saturated does percolation occur into and through the rock. The benefit of the capillary barrier inherent in the soil/rock cap design is that water stored in the topsoil can be removed by evaporatior and transpiration, thereby reducing the potential for percuiation deeper into the profile.

The topsoil and plant cover placed over the rocks are critical components of the soil/rock intrusion barrier design since they function as the primary barrier to biointrusion and deep percolation. The CREAMS model, developed by the US Department of Agriculture has been applied to designing optimum configurations of topsoil and plants to reduce erosion and percolation through a trench cap. While the soil and plant components serve as primary barriers to biological intrusion and deep percolation, the rock material provides a secondary barrier should the primary components fail.

Several limitations on recommending the use of a soil/ rock cap design are presented including the effect of time on barrier performance. Observation periods of less than two years on individual experiments leave serious unanswered questions about continued barrier performance over decade to century time scales. Attendant with the question of time scale are the uncertainties in barrier performance as plant and animal species change due to successional processes.

For arid sites, the probabiliky seems high that the soil/rock cap design will perform over extended time scales when proper attention is given to all the important interrelationships between biological and physical processes acting on the cap. For example, if the cap is designed to manage soil vater in the topsoil over the rock barrier, then the probability of failure of the rock barrier in preventing biointrusion and percolation will be greatly reduced. Saturation of the topsoil, with resulting percolation through the rock, can result in greater percolation into deeper regions than that associated with a conventional cap degizn of soil and tuff.

Finally, cost of applying a gravel/cobble intrusion barrier, based on experience at the low-level waste site at Area $B$ at Los Alamos, is higher than cost for a conventional design. However, the "real" cost of applying the rock design must be evaluated in terms of the future costs of any remedial action after site closeout. 


\section{I . INTRODUCTION}

\subsection{Purpose and Scope of Report}

This repart presents an evaluation of selected configurations of soil and rock in preventing plant root and burrowing animal intrusion through low-level waste site trench caps and into buried waste. That evaluation is based upon

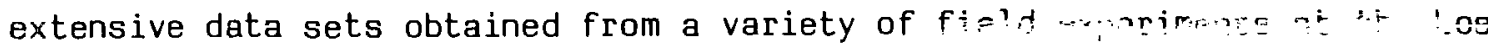
Alamos Experimental Engineered Test Facility (EETF) and at decommissioned and operational low-level waste sites at Los Alamos National Laboratory. The report is organized into three general topics, including the technical issues that may lead to the need for biological intrusion barriers in trench cap design. Experimental data addressing a variety of performance-related questions are also pres snted, and finally, the implications of these data on biointrusion barrier design and performance are discussed relative to design of optimal shallow land burial facilities for low-level waste disposal.

Tre current state of knowledge on the relative importance of biological intrusion in transporting waste to the biosphere, compared with other transport pathways (e.g., percolation of leachates to groundwater), is presently inadequate, particularly in arid/semiarid areas and especially over the time scales for which waste must be isolated. Until that information gap is closed, the question of whether or not biological intrusion barriers are needed is no more or no less important than one on the need for moisture barriers or erosion control.

In addition, there are other approaches to preventing biological intrusion, other than those discussed in this report, that may perform equally well. Virtually all of those approaches, including the use of soil and rock barriers, suffer from lack of availability of information on their long term effectiveness. 
Consequent ly, this report is not intencied as an endorsement of either the need for or use of soil and rock biointrusion barriers in waste designs, but rather is to serve as a guide for identifying the advantages and disadvantages of using these barriers should experimental and/or monitoring data support. their use. As discussed in this report, sil/rock intrusion barriers offer some distinct advantages over conventional trench cap designs but meiy also be subject to dramatic failures under conditions outside their operational limits. 1.2 Background

Shallow land burial (SLB) has been used as a waste disposal technique since the beginning of man. From recorded history, we know that as early as 6000 B.C., Neolithic and pre-Elamite civilizations in what is now Iran uned SLB for disposal of waste (Langer, 1968). In more recent times, as a consequence of expanding populations, industry, and development of nuclear and non-nuclear energy for power, concern has arisen about the adequacy of SLB for containing the potentially hazardous waste by-products generated by these developments.

Low-level radioactive waste (LLW) such as generatec by the nuclear power industry, hospitals, universities, and nuclear research and development facilities, is typically buried in shallow earth excavations of variable size bu' generally averaging $15 \mathrm{~m}$ wide by $15 \mathrm{~m}$ deep by about $200 \mathrm{~m}$ long (Fig.1). Trenches are $₹$ illed with waste consisting of a very heterogeneous mixture of materials, including laboratory trash, reactor parts, and dismantled buildings. A trench cap of about $1-$ to $2-m$ thickness is applied as a final covering to complete isolation of the buried waste from the biosphere.

Over 0 years of operating experience at disposal sites for LLW demonstrates that SLB technology works fairly well in isolating buried radionuclides although virtually every one of the 6 commercial and 5 DOE sites 


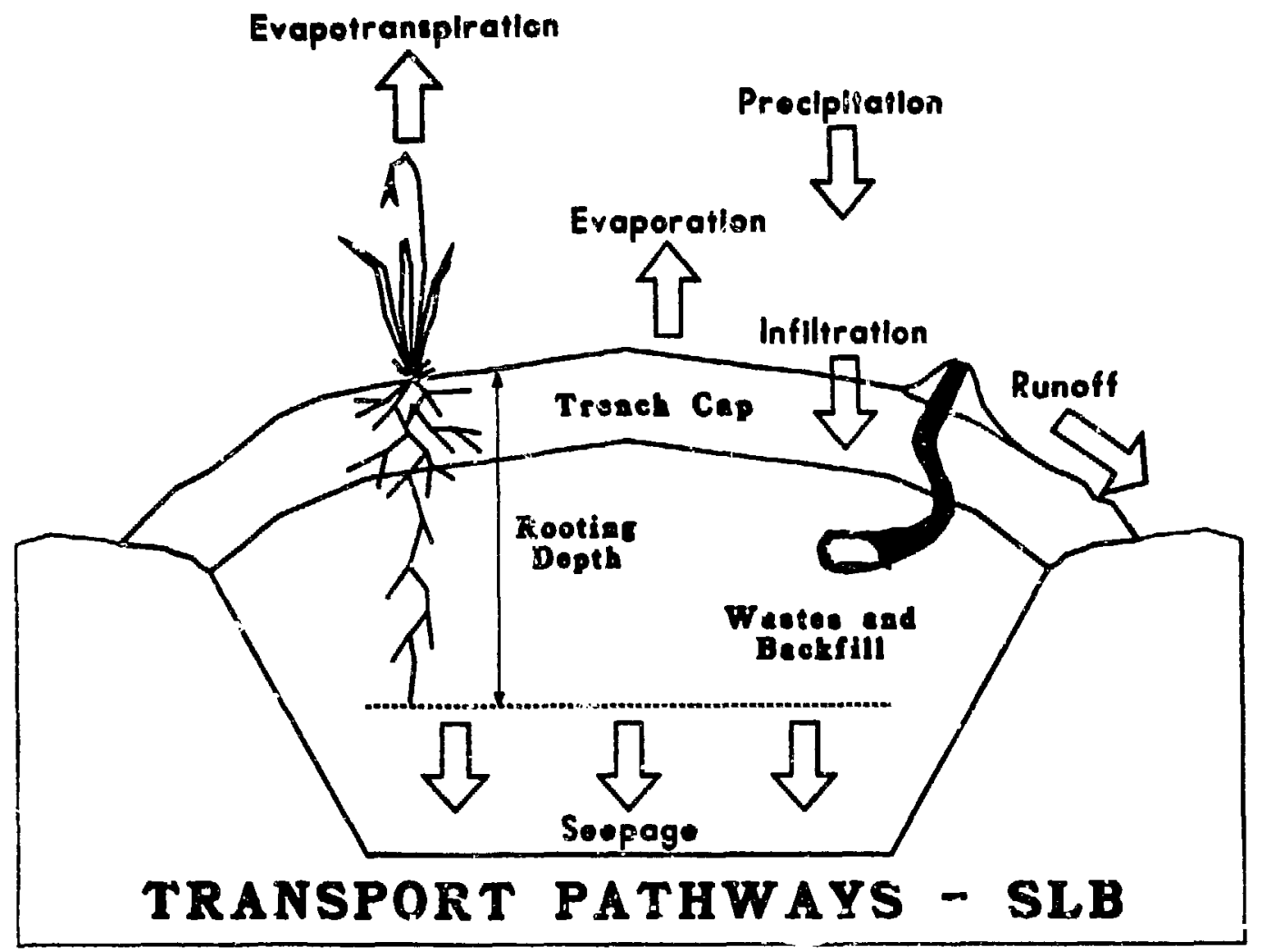

Fig. 1. Hydrologic and hiological processes affecting shallow land burial sites.

has not proved 100\% effecíive (Duguid, 1977; Jacobs et al., 1980; Hakonson, et al., 1982). Of the 6 commercial LI.W sites, only 2 are currently operational; the closure of 3 of the 4 commercial sites is at least partly attributable to unanticipated problems with integrity of the burial site.

If we examine the ecosystem processes that affect site performance, with potential impact on dose to man (Fig. 1), it is apparent that water and soil dynamics, as infiuenced by physical, chemical, and biological factors, account for most of the performance-related problems (Duguid, 1977; Jacobs et al., 1980). For example, erosion assuciated with the runoff from the surface of 
the site can breach the cap and expose waste to the biosphere. Consequently, erosion rates must be within tolerances that leave the cap intact over the 100- to 200-year required lifetime of the facility, Likewise, water that infiltrates into the cap can accumulate in the trench (bathtub effect) and/or percolate in association with solute/s into gound water. Percolation alsu enhances subsidence of the cap as a result of decomposition of bulky waste in the trench. Finally, both plants and animals, besides playing an important role in water balance, can penetrate into the waste and transport radionuclides to the ground surface as a result of root uptake and/or burrowing activities.

Although vegetation is important in controlling erosion and percolation (Hakonson, et al., 1984) deep-rooted plants can access buried radionuclides and bring them to the surface of the site. Radionuclides in plant tissue can be transported through the food chain to man by herbivores or nectarcollecting organisms such as honey bees. At Los Alamos, New Mexico, one of the pathways of tritium transport away from a controlled low-level waste site is via the soil moisture/plant nectar/honey bee/honey pathway (Hakonson and Bostick, 1976); however, radiation doses to humans who might comsume this honey are very small. Likewise, tumbleweeds growing on low-level waste sites are effective in transporting $90_{S r}$ to the ground surface at Hanford, Washington (Klepper, et al., 1979).

The importance of preventing buried waste from reaching the ground surface is illustrated by a pathway representation, of plutonium behavior in terrestrial ecosystems (Fig. 2). Radionuclides buried below the ground surface can be absored by plant roots and deposited in above-ground plant tissue. However, when tine radionuclides are present on the soil surface, as is the case at several waste sites, physical resuspension of soil particles 


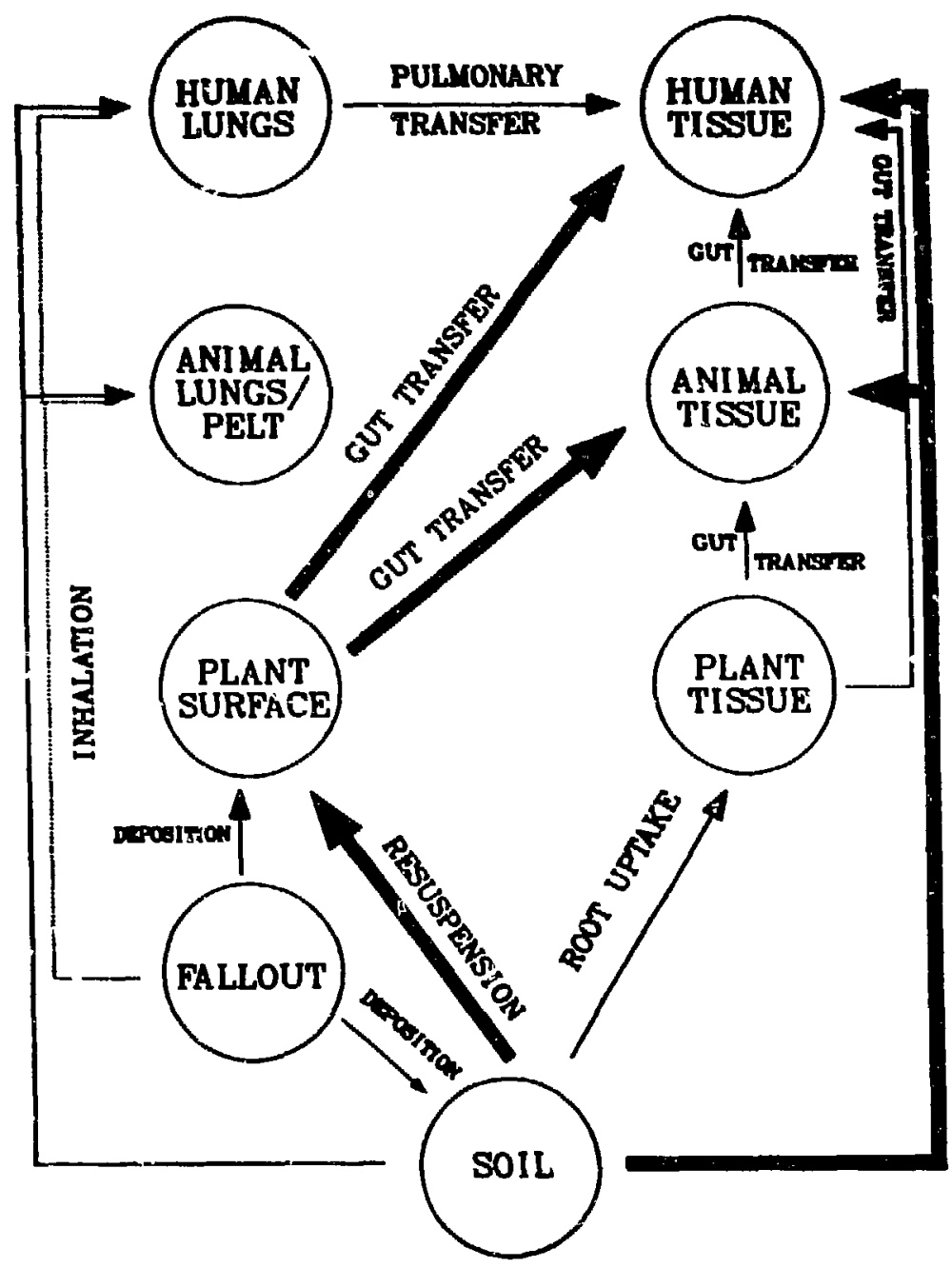

Fig. 2. Transport pathways for plutonium and other radionuclides deposited in the soil compartment of terrestrial ecosystems. Physical transpert of soil particles with subsequent deposition on biological surfaces dominates in the transport of many soil contaminants to biota.

(especially the clays) by wind and watr can deposit contaminated soil particles on plant surface (i.e., leaves, stems, and fruiting bodies; Dreicer, et al., 1984). Field studies (Watters, et al., 1980; Hakonson and Nyhan, 1980) with plutonium, as well as other radionuclides show that for every picocurie taken up through plant roots, at least 10 (and often 100 to 1000) picocuries can be deposited in association with soil particles on foliage 
surfaces. Of course, most herbivores consume those radionuclides whether they are on or in the plant. Even in humans, who usually wash vegetables before consumption, as much as 50\% of the radionuclide intake from consuming certain garden vegetables may be from very small soil particles, such as clays, that are not removed from crop surfaces by standard household food washing procedures (White, et al., 1981).

While plants can mobilize buried waste, they also play an extremely important role in water balance. In arid/semiarid climates, plants may transpire from 65-100\% of the annual precipitation (Saxton, 1982; Federer, 1975). This means that very little soil water may be available for percolation below the root zone.

The role of animal burrowing in mobilizing buried waste is generally unknown. A limited data base (Hakonson, et al., 1982; 0'Farrell and Gilbert, 1975; Winsor and Whicker, 1980; and Arthur and Markham, 1983) demonstrates that burrowing animals can transport radionuclides vertically in the soil profile and may also influence water balance and erosion by changing the physical characteristics (i.e. porosity, water holding capacity) of surface and subsurface soils. Trench covers are disturbed soil systems, often loosely compacted, and are easily invaded by plants and animals. Burrowing ari: nals use the void spaces left after trench backfilling as natural tunnels and nesting sites (Connolly and Landstrom, 1969; Arthur and Markham, 1983).

Burrowing activities by animals play an important role in chemical cycling in the soil profile. The vertical transport of $\mathrm{Fe}, \mathrm{Se}, \mathrm{Al}, \mathrm{Ca}, \mathrm{Mg}, \mathrm{U}, \mathrm{Ra}$, and Th from deep soil layers th the surface by the mechanical action of rodents (Abaturov, 1972; Maslov, et al., 1967) has given rise to the statement that burrowing rodents serve as nutrient pumps that bring materials to the soil surface for weathering (Chew, 1974; Chew, 1976). As mentioned before, soil 
and chemicals brought to the surface are more readily available for resuspension and transport into biological pathways by phyical processes. Although burrowing animals can gain access and transport waste to the ground surface, less obvious intractions with the cover and trench backfill may be of greater importance. For example, pocket gophers inhabiting a low-level waste site at Los Alamos excavated about $12,000 \mathrm{~kg}$ of soil per ha from a trench cover during a l-year peried (́takonson, et alı, 1982a). Displacement of that amount of soil created about $8 \mathrm{~m}^{3}$ of void space in the cover or about $2800 \mathrm{~m}$ of tunnel system. Soil disturbance of a similar or greater magnitude, caused by burrowing animals, has been documented in many parts of the Western US (Gunderson, 1976; Ellison, 1946; Buechner, 1942; Thorpe, 1949; and Hooven, 1971).

Tunnel systems created by pocket gophers in Colorado have been shown to : ?crease rates of water infiltration (by decreasing soil bulk density) into the soil profile by a factoi of two over similar but undisturbed profiles (Grant, 1974; Hanson and Morris, 1968). Compared with undisturbed vegetated soil surfaces, soil cast to the surface by burrowing activity may be subject to accelerated erosion (Ellison, 1946).

Burrowing animals may greatly alter the integrity of engineered, multilayered soil profiles by penetrating through such profiles and/or by vertically displacing the layers. In native ranges, under high population densities, pocket gophers are estimated to turn over 15\% to $22 \%$ of the soil near the surface in a single year (Thorpe, 1949; Hooven, 1971).

Operating experience at the 11 LLW sites in the United 5tates suggests that many of the short term problems that relate to radionuclide transport often do not involve ground water and i.nvariably involve interactions that occur with the trench cap. Those interactions, which involve both water and 
biota, are not well understood, particularly the role that plants and animals play in modifying water balance in the cap and the importance of biological intrusion inte the waste as a radionuclide transport pathway. Few comprehensive, long-term pathway analyses have been attempted to determine the relative importance of subsurface and surface processes in transporting LLW to man. Under a home farm scenario, where a family living on an abandoned low-level waste site at Savannah River Laboratory derived most of their food and water from the site, model calculations suggest that uptake of ${ }^{90} \mathrm{Sr}$ by cereal grains provided the most significant, albeit very low, dose to the family (King, 1982).

The potential significance of the bioloical transport of huried waste in contributing to human exposure to radiation was further explored for both arid and humid site conditions (McKenzie, et al., 1982; McKenzie, et al., 1984) and compared with dose estimates based on several human intrusion scenarios as established by the US Nuclear Regulatory Commission (US NRC, 1981). Results of the simulation study demonstrated that biological transport processes involving both plants and burrowing animals resulted in human exposures 100 years after site closure that were about $50 \%$ of those calculated for the human intrusion scenarios. Despite the uncertainties associated with the dose estimates for all of the scenarios, the study suggests that dismissal of biological transport as a significant contributing factor in radiation exposures to humans is unsupportable with current knowledge.

\subsection{Approaches To Limit Biointrusion}

Desirable features of a biointrusion barrier system include

o effective minimizing of plant root and burrowing animal intrusion into the soil profile and into buried wastes,

o remaining serviceable over the lifetime of the site, 
o no adverse effect on other processes affecting waste site integrity (e.g., erosion or percolation), and

- cost effectiveness.

Several approaches have been suggested to reduce the biointrusion potential at waste disposal sites. Most of those approaches rely on physical or chemical barriers to prevent plant roots and/or burrowing animals from accessing the waste. Examples of physical barrier systems include natural geologic materials such as rocks or manmade barrier materials such as hypalon sheeting or asphalt emulsions. Chemical barrier systems include the use of biotoxins.

Past studies with manmade physical and chemical intrusion barriers lead to questions about the serviceable life of such materials under field conditions. One analysis suggests that materials such ds asphalt, hypalon, and concrete have a field life of no more than 25 years (Pertusa, 1980).

The persistence of herbicides, in general, is not sufficiently long to control vegetation over several decades unless frequent applications are made. Additionally, chemotoxins may adversely affect plant cover and, indirectly, plant transpiration. In arid ecosystems, 65-100\% of the annual precipitation may be transpired by plants back to the atmosphere. Soil water that is not transpired to the atmosphere is available for subsurface iransport. However, recent experiments with polymer beads, which slowly release root growth inhibitors, appear promising for preveriting plant root intrusion (Burton, et al., 1982).

Los Alamos studies on biointrusion barriers emphasized the use of soil and rock beczuse these materials are long lived in the environment, they are relatively inexpensive, and preliminary experiments on their performance had already been conducted by colleagues at Battelle Pacific Northwest Laboratory 
(Cline, et al., 1980). Our work extended that of Cline (Cline, et al., 1980) using carefully designed field experiments and computer modeling.

\section{FIELD EXPERIMENTS}

\subsection{Experimental Approach}

In developing procedures that must eventually be applied at low-level waste sites, the question of experimental scale becomes very important. Experinents conducted at laboratory-bench scale offer advantages in terms of the simplicity and statistical control that can be incorporated into the study. On the other hand, results from such experiments are subject to the criticism of whether they are applicable to field-scale problems. Likewise, the results of field scale experiments, although representing the "real world", are difficult to interpret because of the extremely variable nature of physical, biological, and chemical components of ecosystems in space and time and because it is often not feasible to exercise statistical control of the experiment.

The approash we used to skirt some of these criticisms of methodology was to design studies at scveral scales ranging from relatively small-scale lysimeter studies to field-scale studies on decommissioned LLW site trenches. Based on the foregoing considerations, our small-scale experiment with the lysimeters was amendable to a fairly complex experimental design involving hypothesis testing, whereas progressively larger scale experiments, particularly on LLW sites, were essentially monitoring studies. While the latter studies did not lend themselves to statistical analyses over the short observation periods (1-2 years) associated with these studies, they did address performance-related questions at large scale. 


\subsection{Small Scale Biointrusion Barrier Studies}

A. Methods and Materials. Initial studies at Hanford, Washington, on the use of rock biointrusion barrier systems demonstrated the effectivenes of cobble (3.8- to $7.6-\mathrm{cm}$ diameter) over conventional waste cover profiles of soil in preventing plant and animal intrusion into simulated waste (Cline, et al., 1980). Subsequent laboratory studies (Cline, et al., 1980) indicated that improved performance of the rock barrier was obtained by adding gravel (0.3- to $0.6-\mathrm{cm}$ diameter) over the rock to retard the rate of soil interpenetration into the large air spaces between the rocks. The air spaces between the rocks, which lack water and nutrients, account for the effectiveness of the rock in limiting plant root intrusion. Additionally, the rocks, if of sufficient mass, also prevent the burrowing of most mammals that would occupy a waste site in an arid/semiarid location.

Small-scale, short-term studies were initiated at Los Alamos, New Mexico, in 1981 under funding from the Department of Energy's (COE) National Low-Level Waste Management Program and Ecological Research Division to further evaluate the use of geologic materials as biointrusion barriers at LLW sites (Hakonson, et al., 1981; Hakonson, et al., 1982b; Hakonson, et al., 1982c; and Hakonson, et al., 1983). The hypothesis tested was whether various soil and rock trench cover configurations of fered better protection against biointrusion than conventional cover designs consisting of soil alone. Variables that were examined included soil and rock depth combinations, plant species, and type of barrier material.

The plant root intrusion barrier study was conducted under field conditions (Fig. 3) in 25-cm-diameter polyvinyl chloride lysimeters roughly patterned after those described by Cline (Cline, 1980). Each lysimeter was 
loaded with various combinations of vegetation, soil, and barrier material as illustrated in Table I and Fig. 4.

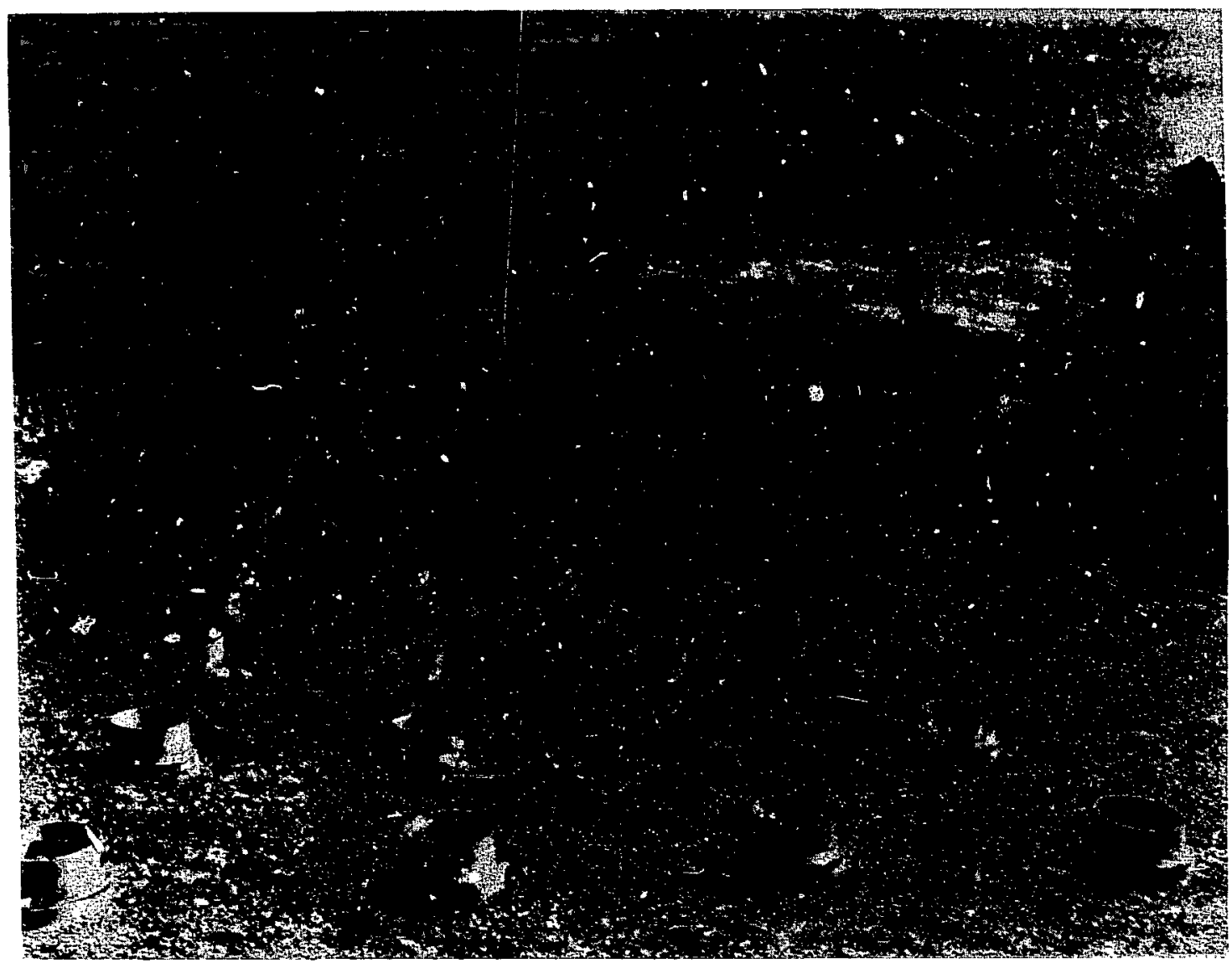

Fig. 3. Small-scale biointrusion study plot showing 25-cm-diameter lysimeter placement in casings and metal culverts in background used for the animal intrusion experiment.

Stable cesium ( $0.5 \mathrm{~g}$ of $\mathrm{CsCl}$ as a solution), which is absorbed by plant roots and translocated to above-ground parts, was applied beneath each cover profile as a simulated waste (Fig. 4). Samples of vegetation were analyzed using neutron activation for cesium at various times throughout the experiment as an indication of root penetration through the barrier materials. The plants selected for the root intrusion study (Table I) were all fast-growing deep-rooted species, including an agriculural annual, barley (Hordeum 
vulgare); a native biernial forb, yellow clover (Melilotus officinalis); and an agricultural perennial, alfalfa (Medicago sativa).

\section{TABLE I}

\section{EXPERIMENTAL DESIGN OF SMALL SCALE PLANT ROOT INTRUSION STUDY}

\begin{tabular}{|c|c|c|}
\hline Variable & Namber & Remarks \\
\hline Plant Species & 3 & Barley, Clover, Alfalfa \\
\hline Topsoil Depth & 2 & $30 \mathrm{~cm}, 60 \mathrm{~cm}$ \\
\hline Barrier Type & 4 & $\begin{array}{l}\text { Crushed Tuff } \\
\text { Bentonite Clay } \\
\text { Cobble } \\
\text { Cobble/Gravel }\end{array}$ \\
\hline Barrier Depth & 3 & $\begin{array}{l}\text { Clay: } 15 \mathrm{~cm}, 30 \mathrm{~cm}, 45 \mathrm{~cm} \\
\text { Others: } 30 \mathrm{~cm}, 60 \mathrm{~cm}, 90 \mathrm{~cm}\end{array}$ \\
\hline Replications & 4 & \\
\hline Total Number & 288 & \\
\hline
\end{tabular}

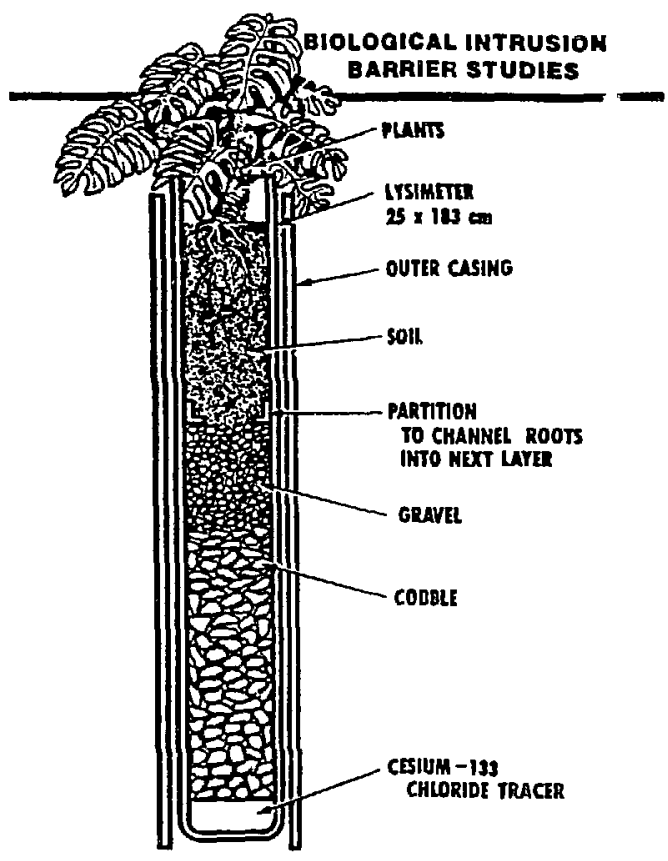

Fig. 4. Experimental soil profile configuration used to elevate geologic materials as root intrusion barriers. 
The topsoil used in the lysimeter study, as well as in all other studies described in this report, was a mixture of a typical Hackroy series soil profile (Nyhan, et al., 1978). That soil has a particle density of 2.5 $\mathrm{Mg} / \mathrm{m}^{3}$, a dry bulk density of $1.34 \mathrm{Mg} / \mathrm{m}^{2}$, and a porosity of 0.47 (Abeele, 1984a).

Low-level waste trenchas at Los Alamos are cut into a welded volcanic ash called tuff. During and after the filling of the trenches, tuff, which has been pulverized by the heavy excavating equipment, is used as a backfill and final cover:ing. Crushed tuff used in the small-scale plant root and animal intrusion study was obtained from stockpiles at the Laboratory's operational low-level wasie site. Crushed tuff has a grain size close to that of sandy silt with a particle density of $2.56 \mathrm{Mg} / \mathrm{m}^{3}$ and a bulk density of $1.4 \mathrm{Mg} / \mathrm{m}^{3}$. The porosity of tuff averages about 0.45 (Abeele, 1984a).

The bentonite clay used in this study was purchased as a commercial product called Aquagel (NL Bariod/NL Industries, Inc., P.0. Box 1675, Houston, TX 77001). This Wyoming bentonite is a colloidal clay (aluminum silicate) composed chiefly of montmorillonite with a high swelling index. Before placing the clay barrier layer within the profile, the dry clay was mixed with water at a rate of about $1: 6$ by weight. Note that the clay barrier thicknesses were cut to one-half of those used for the other materials (Table I) in order to bring the cost of a soil/clay cap design to levels comparable with the other barrier designs.

The cobble/gravel barrier design consisted of 7.5- to 12-cm-diameter washed cobble overlain by 1 - to 2 -cm-diameter washed gravel. The purpose of the gravel layer over the cobble was to retard interpenetration of soil into the spaces bitween the cobbles as was observed by Cline (Cline, et al., 1980). 
The presence of soil between the cobbles would provide a pathway for root penetration downward through the profile and into the waste.

Conditions in the lysimeters were optimized for plant growth to produce maximum root penetration and hence, stress on the barrier systems. The soil was amended with steer manure and commercial fertilizer (0-46-0); plants were watered in a way to produce frequent wetting and drying cycles to encourage root penetration. A total of about $150 \mathrm{~cm}$ (60 in.) of water was applied to each ly:simeter during the course of the 172-day study.

Sta:istical analysis of the data employed the Statistical Package for the Social Sciences (Nie, et al., 1975). The BMDP Biomedical Computer Programs P-Series 1979 (Dixon and Brown, 1979) was used for the log-linear contirgency table analysis.

The enimal intrusion barrier experiment was conducted in four metal culverts ( $1.9-\mathrm{m}$ diameter by $22 \mathrm{~m}$ high) that were placed on end and filled from bottom to top with backfill, $90 \mathrm{~cm}$ of one of the four barrier materials (Table I), and $60 \mathrm{~cm}$ of topsoil. A single pocket gopher (Thomomys Bottae) was maintained in each culvert anc was allowed to construct a burrow system within the cover profile over a period of 4 months. At the conculsion of the study the gophers were removed and the gopher tunnel systems were injected with expanding polyurethane foam to provide a 3-dimensional cast of the tunnel system (Felthauser and McInroy, 1983). The tunnel cast was exposed by excavation to provide a qualitative evaluation of intrusion barrier effectiveness.

B. Results. Based on analysis of the data, vegetation species, biobarrier material, soil and biobarrier thickness, and time were all statistically significant factors $(p<0.05$ ) affecting root penetration. Barrier penetrations by plan species and time are summarized in Table II. 
Early failures of barrier designs as indicated by cesium concentations in ants were largely due to the annual, barley; followed by the biennial, yellow sweet clover; and perennial, alfalfa. At 72 days post-seeding, from about 50-100\% of the barley samples contained elevated cesium depending on barrier type and depth combinations, whereas corresponding values for alfalfa and sweet clover were generally less than 50\%. Those patterns likely reflect the adaptation of annual species such as barley to quickly exploit water and nutrients in the soil.

Differences in barrier penetrations by plant species over the course of the experiment were not obvious for the crushed tuff barrier material because nearly all of the species had penetrated this material within 101 days (Table II). However, for the other barrier materials the number of penetrations by barley peaker early and then decreased with time while those for alfalfa and sweet clover generally increased with time. The differences in root penetration b; species and time cannot be attributed to any one cause; however, thuse causes may include changes in the physical distribution of roots, chanyes in the distribution of absorptive rnots, or changes in the kinetic behavior of cesium in the plants.

TABLE II

RELATIONSHIPS OF BARRIER PENETRATIONS TO PLANT SPECIES, BARRIER MATERIAL, AND TIME POST-SEEDING

\begin{tabular}{|c|c|c|c|c|c|c|c|c|c|c|c|c|}
\hline $\begin{array}{c}\text { Elapsed Time } \\
\text { (Deys) } \\
\end{array}$ & \multicolumn{12}{|c|}{$\begin{array}{c}\text { Barrier Type } \\
\text { (Plant Species) }\end{array}$} \\
\hline 72 & $14^{\prime \prime}$ & 24 & 17 & 3 & 13 & 7 & 1 & 11 & 0 & 0 & 15 & 0 \\
\hline 101 & 23 & 24 & 22 & 2 & 3 & 9 & 3 & 18 & 1 & 0 & 16 & 0 \\
\hline 119 & 23 & 23 & 22 & 5 & 1 & 7 & 1 & 15 & 1 & 3 & 16 & 1 \\
\hline
\end{tabular}

Number of barrier penetrations duc 10 i... icated plant species; a value of $24(n=24)$ indicates $100 \%$ penetration. 
TABLE III

NUMBER OF ROOT PENETRATIONS THROUGH CRUSHED TUFF
AS A FUNCTION OF CAP DEPTH AND TIME POST-SEEDING

Elapsed Time

Soil Barrier Depth Combinations

\begin{tabular}{|c|c|c|c|c|c|c|}
\hline (bays) & $30-30^{2}$ & $60-30$ & $30-60$ & $60-60$ & $30-90$ & $60-90$ \\
\hline 72 & $12(100)^{b}$ & $12(100)$ & $12(100)$ & $8(67)$ & $7(58)$ & $4(33)$ \\
\hline 101 & $12(100)$ & $12(10$ & & $12(100)$ & $12(100)$ & $9(75)$ \\
\hline 119 & $12(100)$ & $11(92)$ & $12(100)$ & $12(100)$ & $12(92)$ & $9(75)$ \\
\hline 148 & $12(100)$ & $12(100)$ & $12(100)$ & $9(75)$ & $12(100)$ & $9(75)$ \\
\hline 172 & $11(92)$ & $11(92)$ & $12(100)$ & $11(92)$ & $10(83)$ & $7(58)$ \\
\hline
\end{tabular}

'Soil Depth - Barrier Depth in centimeters.

bumber of root penetrations and percent of total $(n=12)$ penetrated (parenthetical values).

If we examine barrier failures as a function of soil and barrier depth combinations, we see that crushed tuff (Table III) offers little or no protectin against root intrusion even at total cap thicknesses of $150 \mathrm{~cm}$ where up to $75 \%$ of these designs failed. The ratios of topsoil to tuff thickness (e.9., 2:1, 1:1, 1:2, or $1: 3$; see Table III) had no measurable effect on barrier performance under the conditions of this study.

\section{TABLE IV}

NUMBER OF ROOT PENETRATIONS THROUGH BENTONITE CLAY AS A FUNCTION OF CAP DEPTH AND TIME POST-SEEDING

\begin{tabular}{|c|c|c|c|c|c|c|}
\hline \multirow{2}{*}{$\begin{array}{c}\text { Elapsed } \\
\text { Time } \\
\text { (Days) }\end{array}$} & \multicolumn{6}{|c|}{ Soil Barrier Depth Combinations } \\
\hline & $30-15^{2}$ & $60-15$ & $30-30$ & $60-30$ & $30-45$ & $60-45$ \\
\hline 72 & $10(83)^{a}$ & $4(33)$ & $7(58)$ & $1(8)$ & $1(8)$ & $0(0)$ \\
\hline 101 & $5(42)$ & $1(8)$ & $4(33)$ & $2(25)$ & $2(17)$ & $0(0)$ \\
\hline 119 & $4(33)$ & $1(8)$ & $4(33)$ & $0(0)$ & $3(25)$ & $1(8)$ \\
\hline 148 & $5(42)$ & $3(25)$ & $2(17)$ & $0(0)$ & $1(8)$ & $2(17)$ \\
\hline 172 & $6(50)$ & $1(8)$ & $6(50)$ & $1(8)$ & $3(25)$ & $1(8)$ \\
\hline
\end{tabular}

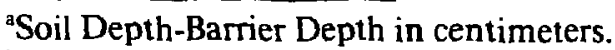

${ }^{b}$ Number of root penetrations and percent of total $(n=12)$ penetrated (parenthetical values). 
In contrast, the clay, cobble, and cobble/gravel barrier systems were all much more effective than crushed tuff in limiting root intrusion even at minimum soil and barrier thickness combinations (Tables IV-VI, Fig. 5). For example, 172 days after seeding, $86 \%$ (62 out of 72) of the plant samples from the crushed tuff barrier designs had elevated cesium concentrations, whereas corresponding values for clay, cobble, and cobble/gravel, respectively, were 25\%, 21\%, and 15\%. Increasing the soil and barrier thickness greatly improved performance of the clay, cobble, and cobble/gravel basrier systems (Tables IV-VI). Maximum soil/barrier thickness combinations of $150 \mathrm{~cm}$ through the cobble and cobble/gravel barrier designs generally reduced root intrusion to less than $20 \%$.

\section{TABLE V}

NUMBER OF ROOT PENETRATIONS THROUGH COBBLE AS A FUNCTION OF CAP DEPTH AND TIME POST-SEEDING

\begin{tabular}{|c|c|c|c|c|c|c|}
\hline \multirow{2}{*}{$\begin{array}{c}\text { Elapsed Time } \\
\text { (Days) }\end{array}$} & \multicolumn{6}{|c|}{ Soil Barrier Depth Combinations } \\
\hline & $30-30^{\circ}$ & $60-30$ & $30-60$ & $60-60$ & $30-90$ & $60-90$ \\
\hline 72 & $5(42)^{b}$ & $3(25)$ & $3(25)$ & $O(0)$ & $1(8)$ & q(0) \\
\hline 101 & $7(58)$ & $4(33)$ & $3(25)$ & $3(25)$ & $3(25)$ & 2(17) \\
\hline 119 & $6(50)$ & $3(25)$ & $2(17)$ & $2(17)$ & $3(25)$ & $1(8)$ \\
\hline 148 & $7(58)$ & $2(17)$ & $3(25)$ & $2(17)$ & $2(17)$ & $0(0)$ \\
\hline 172 & $s(42)$ & $3(25)$ & $4(33)$ & $1(8)$ & $i(8)$ & $1(8)$ \\
\hline
\end{tabular}

- Soil Depth-Barrier Depth in centimeters.

Number of root penetrations and percent of total $(n=12)$ penetrated (parenthetical values).

TABLE VI

NUMBER OF ROOT PENETRATIONS THROUGH COBBLE/GRAVEL AS A FUNCTION OF CAP DEPTH AND TIME POST-SEEDING

\begin{tabular}{|c|c|c|c|c|c|c|}
\hline \multirow{2}{*}{$\begin{array}{l}\text { Elnpsed Time } \\
\text { (Days) }\end{array}$} & \multicolumn{6}{|c|}{ Soll Burrier Depth Combinations } \\
\hline & $30-30^{\circ}$ & $60-30$ & $30-60$ & $60-60$ & $30-90$ & $60-90$ \\
\hline 72 & $4(33)^{n}$ & $2(17)$ & $4(33)$ & $4(33)$ & $I(8)$ & $0(0)$ \\
\hline 101 & $4(33)$ & $2(17)$ & $4(33)$ & $3(25)$ & $2(17)$ & $1(8)$ \\
\hline 119 & $6(50)$ & $3(25)$ & $4(33)$ & $3(25)$ & $2(17)$ & $2(17)$ \\
\hline 148 & $4(33)$ & $2(17)$ & $i(8)$ & $i(8)$ & $O(0)$ & $i(8)$ \\
\hline 172 & $3(25)$ & $3(25)$ & $1(8)$ & $3(25)$ & $0(0)$ & $1(8)$ \\
\hline
\end{tabular}

Soil Depth - Barrier Depth in centimeters.

"Number of root penetrations and percent of total $(n=12)$ penetrated (parenthetical values). 


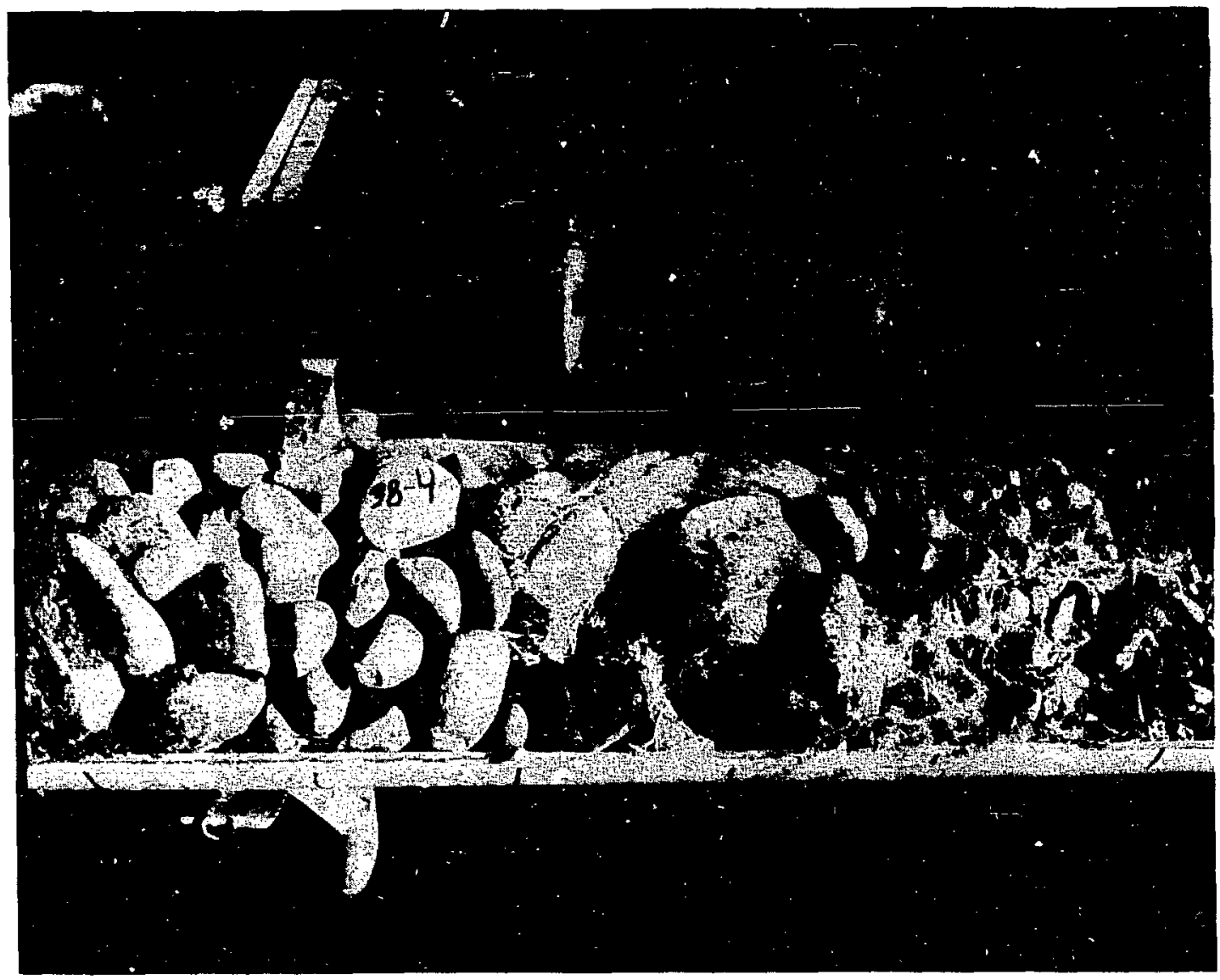

Fig. 5. Root penetration into a topsoil-gravel/cobble intrusion barrier cap design. Effect of cobble in inhibiting root penetration is apparent.

Although clay, cobble, and cobble/gravel barrier designs performed similarly in this short-term experiment, some potentially serious problems were encountered with the use of bentonite clay and cobble as barrier materials. Bentonite clay, which was saturated with water before use, was subject to shrinking caused by depletion of water from the clay by plants (Figs. 6 and 7). Visual examination of exposed root profiles (Fig. 7) confirmed that plant roots were highly concentrated in che clay barrier. 


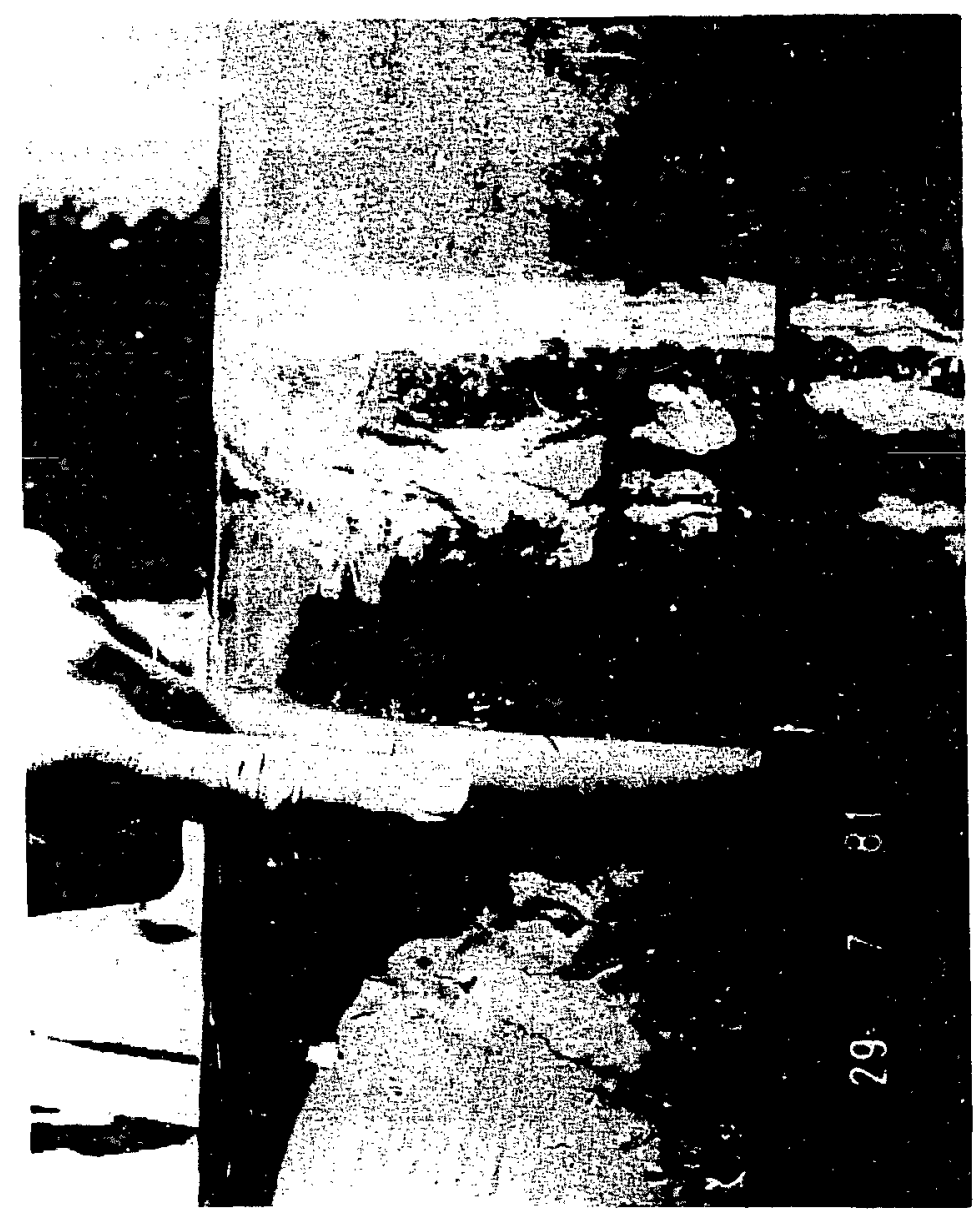

Fig. 6. Shrinking of bentonite clay intrusion barrier, J days after seeding the lysimeters; effect caused by plant transpiration. Note that clay shrinkage occurs in the presence of water ponded on the surface of the clay.

Despite the fact that water was often ponded above the clay (Fig.6), transpiration losses of water from the clay far exceeded the rate at which the clay could rehydrate.

Visual examination of profiles containing cobble barriers revealed that che large pore spaces between the rocks were filling with soil over-burden. As such cobble may not be an effective barrier over long periods of time because the soil between the rocks provides a pathway for root growth as was 


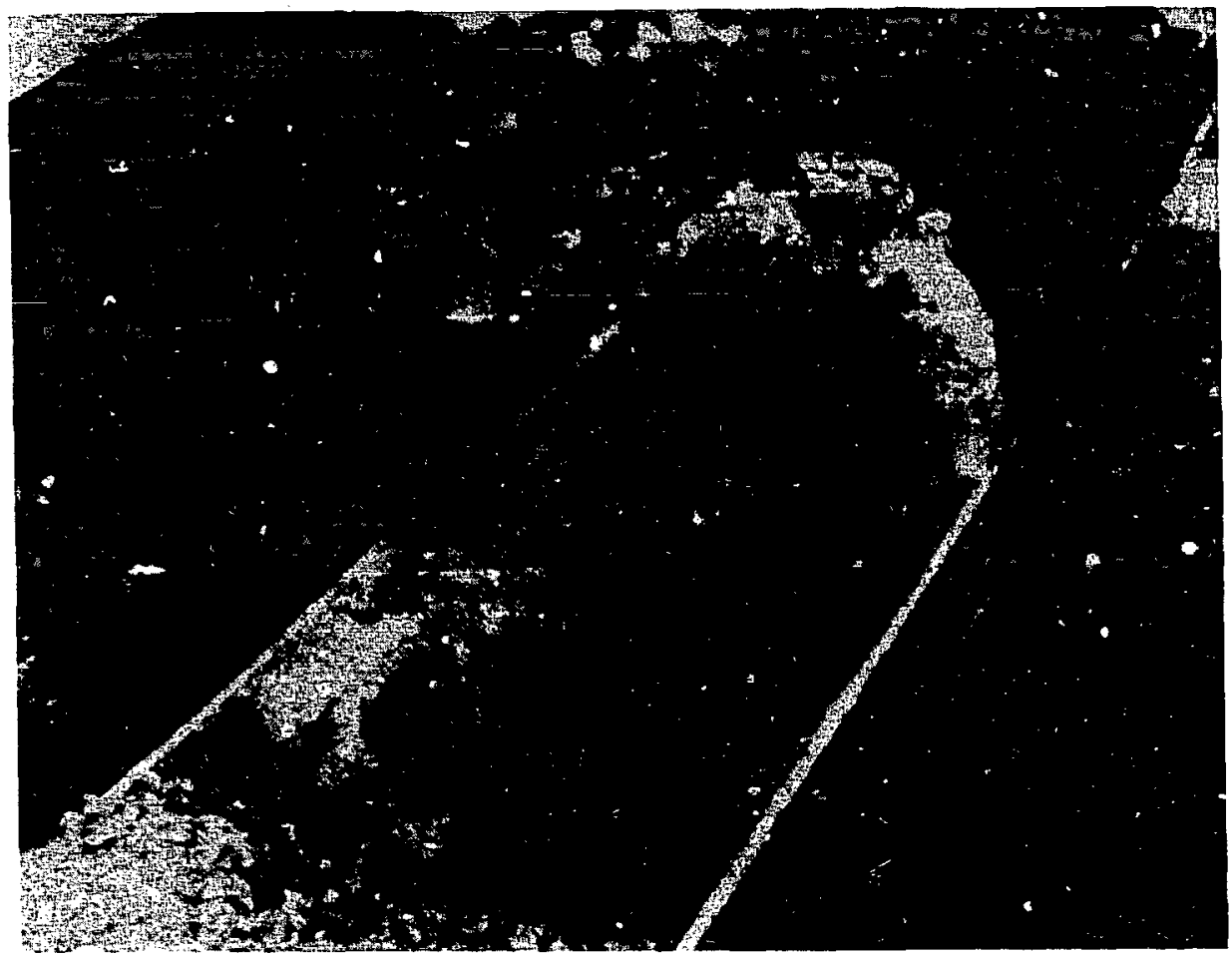

Fig. 7. Clay barcier showing extreme shrinkage and drying 180 days after seeding the lysimeters. Moisture loss from clay was due to plant transpiration.

observed by Cline (Cline, et $31 ., 1980$ ). The 2-cm-diameter gravel, which was placed over the cobble in the cobble/gravel cap design, retarded the rate of soil migration into the cobble, although the degree of retardation was not quantified.

Results of the animal intrusion experiment demonstrated that cobble, cobble/gravel, and bentonite clay were equally effective in preventing animal intrusion with depth (Fig. 8) (Hakonson, et al., 1982c). The reasons for the 


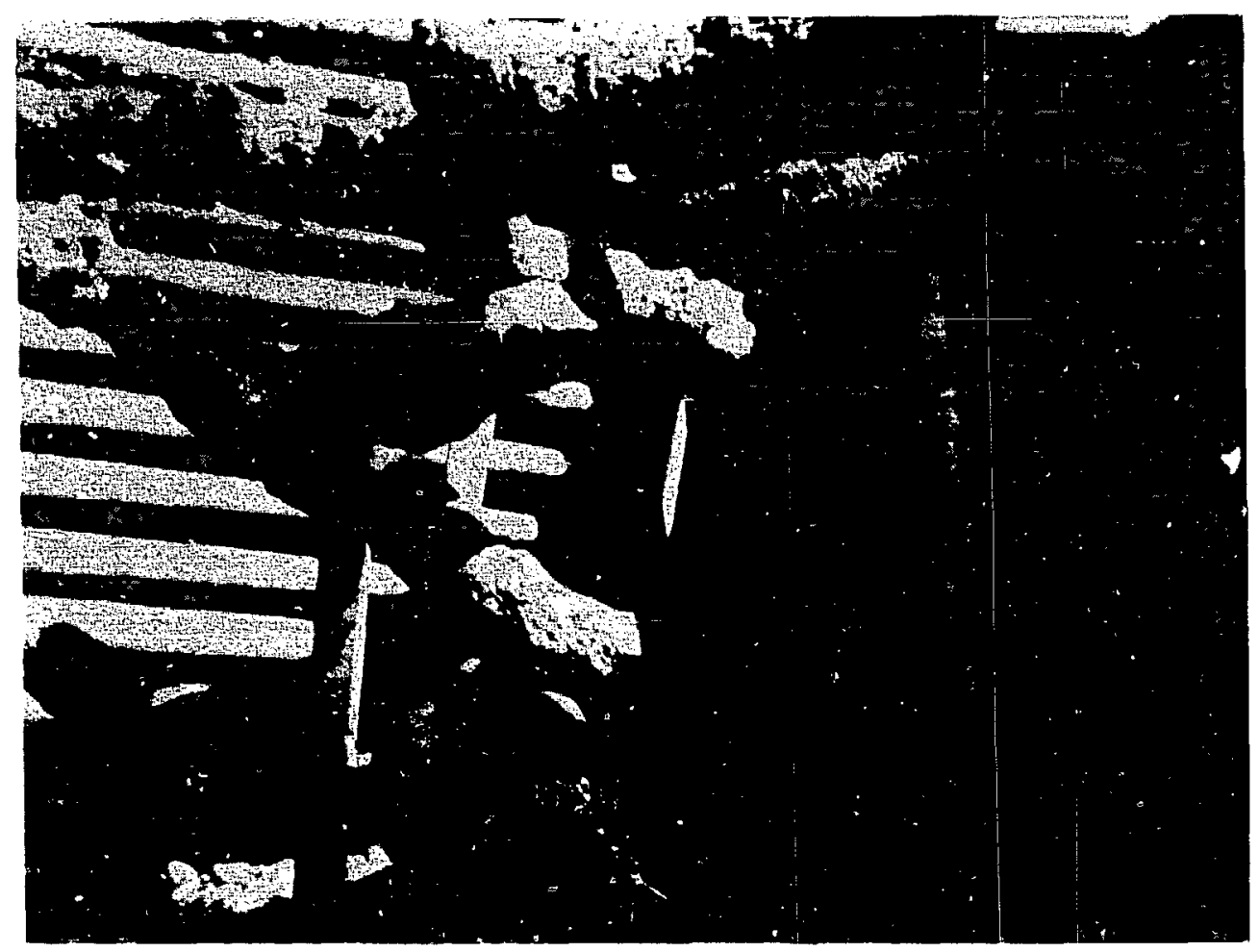

Fig. 8. Polyurethane foam cast of excavated pocket gopher burrow system showing that intrusion was inhibited at the topsoil and gravel interface.

effectiveness of those materials in preventing burrowing below the barrier included the large mass of the cobble (far greater than the 100-200-g mass of the gopher), the noncohesiveness of the gravel (tunnels could not be maintained), and the wet, sticky consistency of the clay (no plants grew on the soil/clay barrier to cause shrinking and drying). The crushed tuff barrier, however, was readily used for tunneling and offered little resistance to burrowing activity (Fig. 9). 


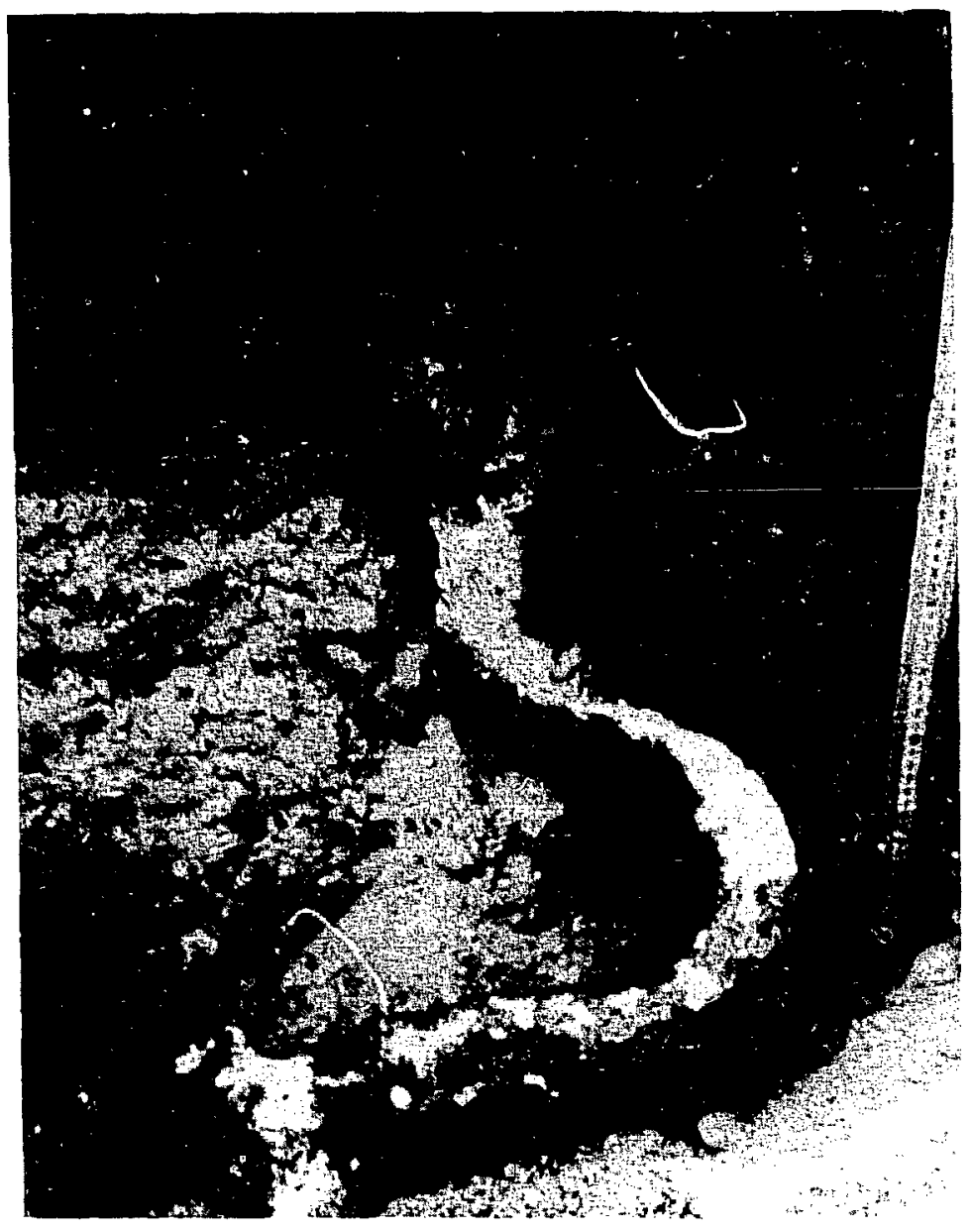

Fig. 9. Polyurethane foam cast of pocket gopher tunnel system showing intrusion through topsoil into crushed tuff barrier material. Also note light circular tuff material blocking old tunnel in topsoil, showing that materials are displaced vertically within the soil profile by burrowing animals.

For reasons discussed previously, bentonite clay would probably not be effective as an animal intrusion barrier because of the plant-associated drying and shrinking of the clay. Additionally, cobble, although effective in preventing animal burrowing, may not be a viable long-term plant root intrusion barrier because of the interpenetration of soil into the rock. 
Although visual examination of soil excavated by the gophers suggested that burrowing occurred in the gravel overlying the cobble, tunnels could not be maintained in this loosely aggregated material.

Both quantitative and qualitative data from the small-scale lysimeter study indicated that an intrusion barrier of $25 \mathrm{~cm}$ of gravel over $75 \mathrm{~cm}$ of cobble performed better than the other barrier materials under the conditions of the study. However, at least four concerns related to the use of cobble/gravel barrier systems were not addressed by the lysimeter study including (1) performance of cobble/gravel intrusion barrier systems over extended time frames, (2) performance at field scale under natural precipitaton regimes with native vegetation, (3) performance under various degrees of subsidence, and (4) effects on water balance, and particularly, percolation through the cover profile. The intermediate and field-scale studies descrihed in following sections were designed to address some of those concerns.

\subsection{Intermediate Scale Biointrusion Barrier Studies}

\section{A. Area $G$}

1. Methods and Materials. The Laboratory's low-level waste management operations group, in the process of closing out a trench at Area $G$ in late 1981, provided the opportunity to install an intermediate-scale biointrusion experiment on the site. In order to address some of the issues raised by the small-scale lysimeter study, an experiment was designed to monitor the performance of several trench cap designs with respect to plant root intrusion and percolation of water into the trench backf 11 .

As mentioned previously, the use of rock materials in intrusion barrier designs leads to questions about the effects of such materials on water balance and particularly percolation. Obviously, replacing a layer of crushed 
tuff within the trench cap with an equal depth of rock greatly zeduces the soil moisture storage capacity and increases the permeability of the cap. Consequently, the amount of water that percolates into the trench backfill may be enhanced unless special consideration is given to replacing storage capacity. One method of replacing maisture storage capacity would be to increase topsoil depth over the rocks. However, in order to produce accelerated and thus observable treatment effects over the 2-year life of the Area $G$ study, topsoil depths over the barriers were purposefully applied at less than optimum depth.

Four plots, $6 \mathrm{~m} \times 12 \mathrm{~m}$ each, were constructed on trench 25 at Area $G$ and employed $1 \mathrm{~m}$ of four different barrier configurations covered with only $15 \mathrm{~cm}$ of Hackroy series topsoil (Fig. 10). Although the 15-cm-topsoil depth

\section{INTERMEDIATE SCALE BIO-INTRUSION BARRIER EXPERIMENT AREA G LOS ALAMOS NATIONAL LABORATORY \\ 15 CX TOPSOIL 100 CU BIO-INTRUSION BARRIER}

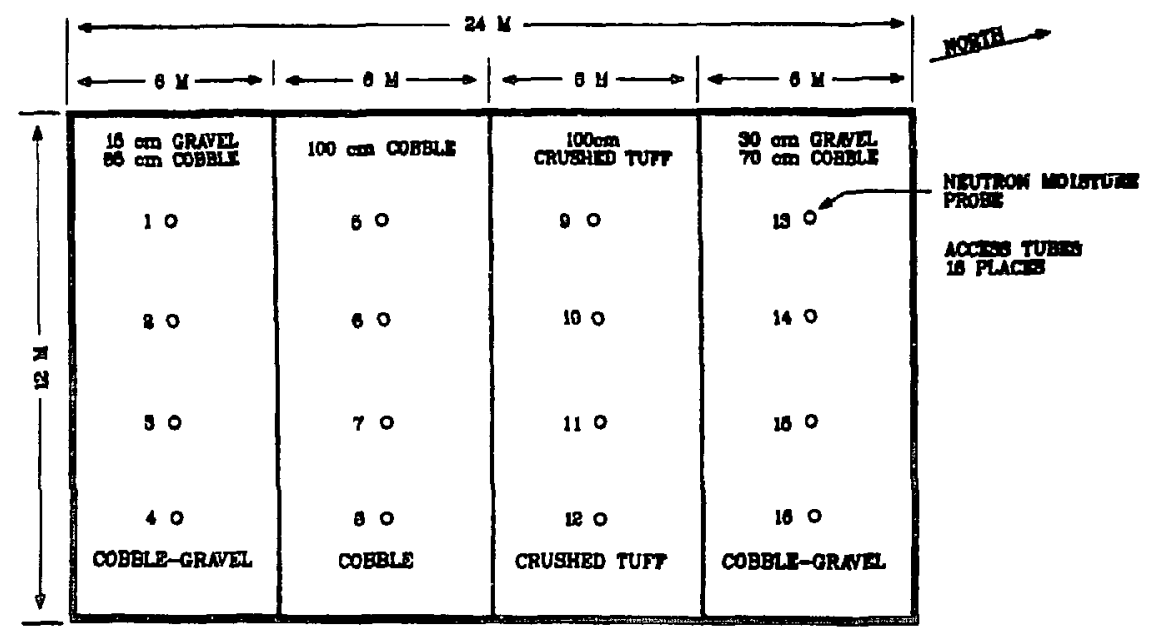

Fig. 10. Intermediate-scale biointrusion barrier experiment at Area G. 
provided relatively little soil moisture storage capacity (about $6 \mathrm{~cm}$ of water at saturation), it did increase the probability of root intrusion and percolation occurring into and through the various intrusion barriers for purposes of determining the characteristics and magnitude of these failure modes. Thus, any precipitation event that resulted in greater than $6 \mathrm{~cm}$ of infiltration into the topsoil had a high probability of water percolating into the biobarrier, and in the case of the rock barrier systems with little water storage capacity, into the underlying backfill.

One plot, which served as a control, approximated the current practice of applying a trench cap of $1-\mathrm{m}$ crushed tuff covered with $15 \mathrm{~cm}$ of topsoil. The other three plots consisted of various combinations of cobble and gravel covered with $15 \mathrm{~cm}$ of topsoil (Fig. 10). A 4-5\% slope provided for some surface runoff.

Galvanized roofing material was used to delineate plot boundaries (Fig. 11) in order to facilitate plot construction and to prevent soil water interflow between plots. Neutron moisture gauge access tubes were installed to a depth of $30 \mathrm{~cm}$ into the backfill underlying eact. cap design to allow for monitoring of soil moisture in the backfill. Cesium chloride was applied at a rate of $30 \mathrm{~g} / \mathrm{mi}^{2}$ to the backfill-biobarrier interface to serve as a simulated waste for evaluating root intrusion. The plots were then filled with the appropriate barrier material (Fig. ll) and topsoil before seeding with a mixture of nine native grass species (Table VII).

Soil moisture in the backfill underlying the caps was measured with a Campbell Pacific model 503 neutron moisture gauge to provide an indirect measure of percolation. Vegetation samples (5/plot/sampling period) were collested periodically throughout the study and analyzed for cesium using 
neutron activation analysis (Gladney, et al., 1984). The only water added to the plots was natural precipitation.

\section{TABLE VII}

GRASS SPECIES AND SEED APPLICATION RATES USED IN REVEGET ATING THE AREA G INTERMEDIATE-SCALE BIOINTR USION BARRIER STUDY

\begin{tabular}{|c|c|c|}
\hline Common Name & Scicñific Name & $\begin{array}{l}\text { Successfully } \\
\text { Established }\end{array}$ \\
\hline Blue gramma & Bouteloua gracilis & $\checkmark$ \\
\hline Western wheatgrass & Agropvron smithii & \\
\hline Crested wheatgrass & Agropyron cristatum & $\checkmark$ \\
\hline Sand dropseed & Sporobolus airoides & $\checkmark$ \\
\hline Little bluestem & Schizarhyrium scoparium & \\
\hline Hard fescue & Fesiuca sp. & \\
\hline Tall fescue & Festuca sp. & \\
\hline Russian wild rye & Elymus glaucus & \\
\hline Smooth brome & Bromus inermis & $\checkmark$ \\
\hline
\end{tabular}

"Each species seeded at the rate of $7.3 \mathrm{~kg} / \mathrm{ha}$ ( $6 \mathrm{lb} / \mathrm{acre}$ ).

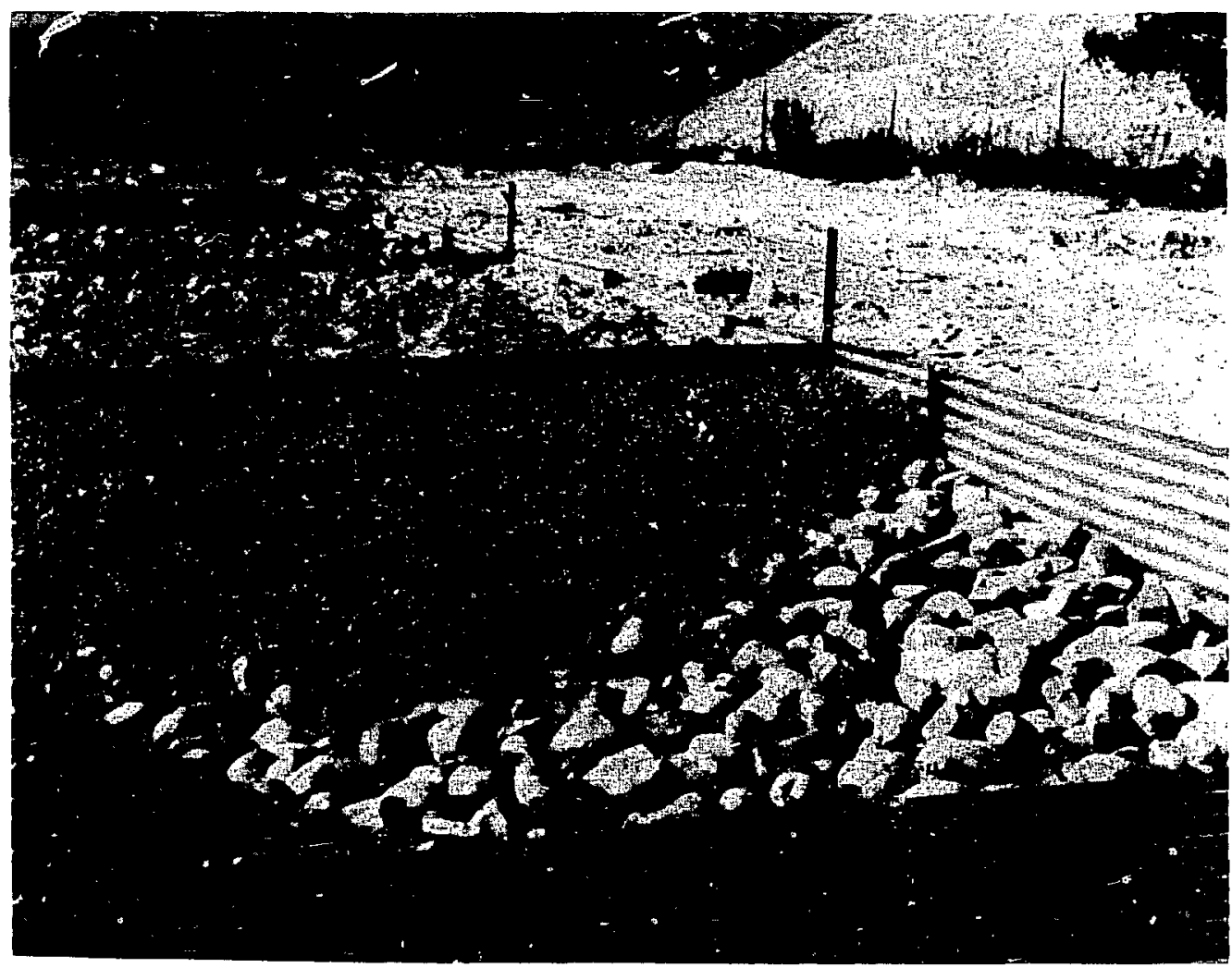

Fig. 1l. Four biointrusion barrier plots under construction on trench 25 at Area G ir. 1981. Galvanized metal plot borders, nsutron access tubes, and portions of the barrier materials are shown just piior to adding the final $15 \mathrm{~cm}$ of topsoil. 
2. Results. Cesium concentrations in individual vegetation samples from the Area $G$ intrusion barrier study are presented in Appendix A (Tables A-I A-IV), while average concentrations by sampling date are presented in Table VIII. In general, cesium concentrations in all samples averaged less than background levels of 1 ppm or less (Table VIII) although concentrations in individual samples measured as high as 83 ppri (Tables A-I - A-IV) or about 100 times background. Two of the intrusion barrier designs (one using cobble and one using gravel and cobble) proved to be essentially 100\% effective in preventing root penetration to the cesium layer over the i5-month study period. A relatively high percentage $(15-20 \%)$ of the samples from the soil-crushed tuff and soil-gravel/cobble (15-cm gravel-85 cm cobble) plots exhibited higher than background levels of cesium while the remaining gravel/cobble (30-cm gravel, 70-cm cobble) and the cobble barrier design each had one sample with elevated cesium. Based upon means by sampling date, the two gravel/cobble designs had one and three values higher than background levels ( $\leq 1 \mathrm{ppm}$ ) of cesium in plants (Table VIII) while the crushed tuff, or control treatment, had four.

TABLE VIII

AVERAGE $(0=4)$ CESIUM CONCENTRATIONS (PPM) IN VEGETATION GROWING ON

AREA G BIOINTRUSION BARRIER PLOTS

\begin{tabular}{|c|c|c|c|c|}
\hline \multirow{2}{*}{$\begin{array}{l}\text { Sampling } \\
\text { Date }\end{array}$} & \multicolumn{4}{|c|}{ Bioburrier Material } \\
\hline & Gravel/Cobbies" & Crushed Tuf & Cobble & Gravel/Cobble' \\
\hline June 22,1982 & $0.18(0.08)$ & $0.24(0.15)$ & $\overline{0.58(0.33)}$ & $1,1 ! \cdots$ \\
\hline $\begin{array}{l}\text { July } 2,1982 \\
\text { July } 12,1982\end{array}$ & $\begin{array}{l}0.14(0.05) \\
0.24(0.05)\end{array}$ & $\begin{array}{l}1.11 .1 \\
0.58(0.39)\end{array}$ & $\begin{array}{l}0.32(0.11) \\
0.62(0.35)\end{array}$ & $\frac{1}{1} \cdot \frac{1}{n}$ \\
\hline September 15,1982 & $0.16(0.05)$ & $0.20(0.10)$ & $0.64(0.99)$ & $0.22(0.08)$ \\
\hline September 27,1982 & $0.10(0.06)$ & $0.08(0.04)$ & $0.11(0.05)$ & $0.19(0.18)$ \\
\hline October 8,1982 & $0.12(0.08)$ & $0.14(0.05)$ & $0.16(0.14)$ & $0.12(0.04)$ \\
\hline October 18,1982 & $0.12(0.05)$ & $5(1)+1$ & $0.09(0.01)$ & $0.30(0.2 .3)$ \\
\hline November 1.1982 & $0.09(0.02)$ & $0.18(0.05)$ & $0.20(0.11)$ & $0.25(0.18)$ \\
\hline April 14. 1983 & $0.66(0.24)$ & $0.61(0.12)$ & $0.68(\mathrm{C} .16)$ & $0.90(0.16)$ \\
\hline June 8,1983 & $0.13(0.06)$ & $0.17(0.09)$ & $0.13(0.03)$ & $0.56(0.52)$ \\
\hline July 27,1983 & $0.15(0.06)$ & $0.29(0.25)$ & $0.25(0.09)$ & $0.43(0.46)$ \\
\hline August 29,1983 & $0.11(0.06)$ & 1111 & $0.14(0.09)$ & $0.47(0.47)$ \\
\hline October 4,1983 & $0.18(0.04)$ & $0.29(0.09)$ & $0.14(0.02)$ & $0.21(0.13)$ \\
\hline November 8,1983 & $\therefore 1 m$ & (B०) & $0.14(0.03)$ & $0.40(0.24)$ \\
\hline
\end{tabular}

"Barrier consisted of $15-\mathrm{cm}$ gravel over $85-\mathrm{cm}$ cobble.

barrier consisted of 30-cm gravel over 70-cm cobble.

c Cesium concentrations elevated above background lcvels of $\leq 1 \mathrm{ppm}$ are highlighted. 
The overall mean cesium concentrations in plants across all sampling ciates (Tabie IX) ranged from 0.3-1 ppm for the three rock barrier designs but averaged $2.7 \mathrm{ppm}$ for the tuff-barrier design. Mean conccntrations for two of the rock designs (30-cm gravel over $70-\mathrm{cm}$ cobble and $100-\mathrm{cm}$ cobble) were significantly $(p<0.05)$ less shan the 2.7 -ppm average for the soil tuff design. Differences in cesium concentrations in plants from the soil/tuff and 15-cm-gravel/85-cm-cobble designs were not significant $(p<0.05)$.

\title{
TABLE IX
}

\begin{abstract}
CESIUM CONCENTRATIONS (PPM) AVERAGED ACROSS 4LL SAMPLING DATES FOK THE FOUR BIOLOGICAI INTRUSION BA RRIER DESIGNS EMPLACED ON AREA G
\end{abstract}

\begin{tabular}{|c|c|c|c|c|}
\hline & \multicolumn{4}{|c|}{ Bioinurusion Barrier Material } \\
\hline & $\begin{array}{l}30 \mathrm{~cm} \text { Gravel } \\
70 \mathrm{~cm} \text { Cobble }\end{array}$ & $\begin{array}{c}\text { Crasshed } \\
\text { Tuff }\end{array}$ & Cohble & $\begin{array}{l}15 \mathrm{~cm} \text { Gravel } \\
85 \mathrm{~cm} \text { Cobble }\end{array}$ \\
\hline Mean & 0.33 & 2.7 & 0.30 & 1.1 \\
\hline S.D. & 1.1 & 0.8 & 0.35 & 2.8 \\
\hline Range & $0.1-9.3$ & $0.1-83$ & $0.1-1.1$ & $0.1-18$ \\
\hline & 70 & 70 & 70 & 70 \\
\hline
\end{tabular}

Time serits measurements of soil moisture taken $30 \mathrm{~cm}$ into the backfill underlying the four cap desigr.s are presented in Fig. 12, while daily and monthly precipitation and snow depth data for Area G are presented in Fig. 13 and Table $X$. The value far a particular sampling date an each curve in Fig. 12 represente the average based on four moisture measurements made in each plot (Fig. 10).

Important features of the data are that percolation of water through all four cap designs vecurred several times over the 31-month observation period and that soil moisture in the backfill generally increased with time following a step function pattern. Several sharp increases in backfill moisture coincided with precipitation events, and in particular snowmelt during mid- to 


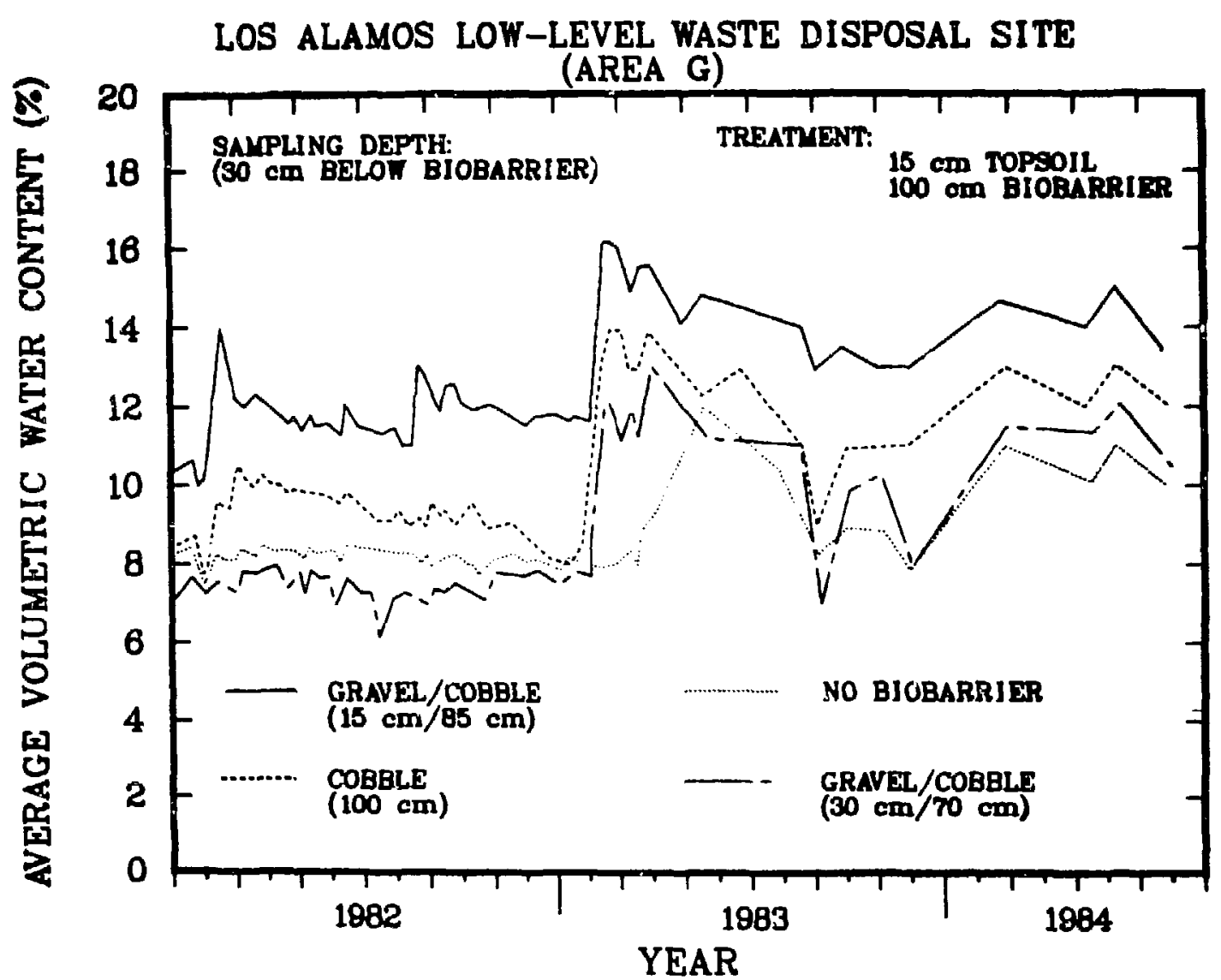

Fig. 12. Volumetric water content of backfill under the biointrusion barrier cap designs at Area G.

late winter. Backfill moisture during the summer growing season was relatively constant or decreased slightly despite the occurrence of several large summer rainstorms which, on average, contribute about 75\% if the annual precipitation at Los Alamos. The data suggest that even though very little moisture storage capacity was available in the $15 \mathrm{~cm}$ of topsoil, that capacity, when coupled with the large losses of soil water to evapotranspiration, was sufficient to prevent percolation into the backfill during the summer months. However, during winter when plant transpiration was 


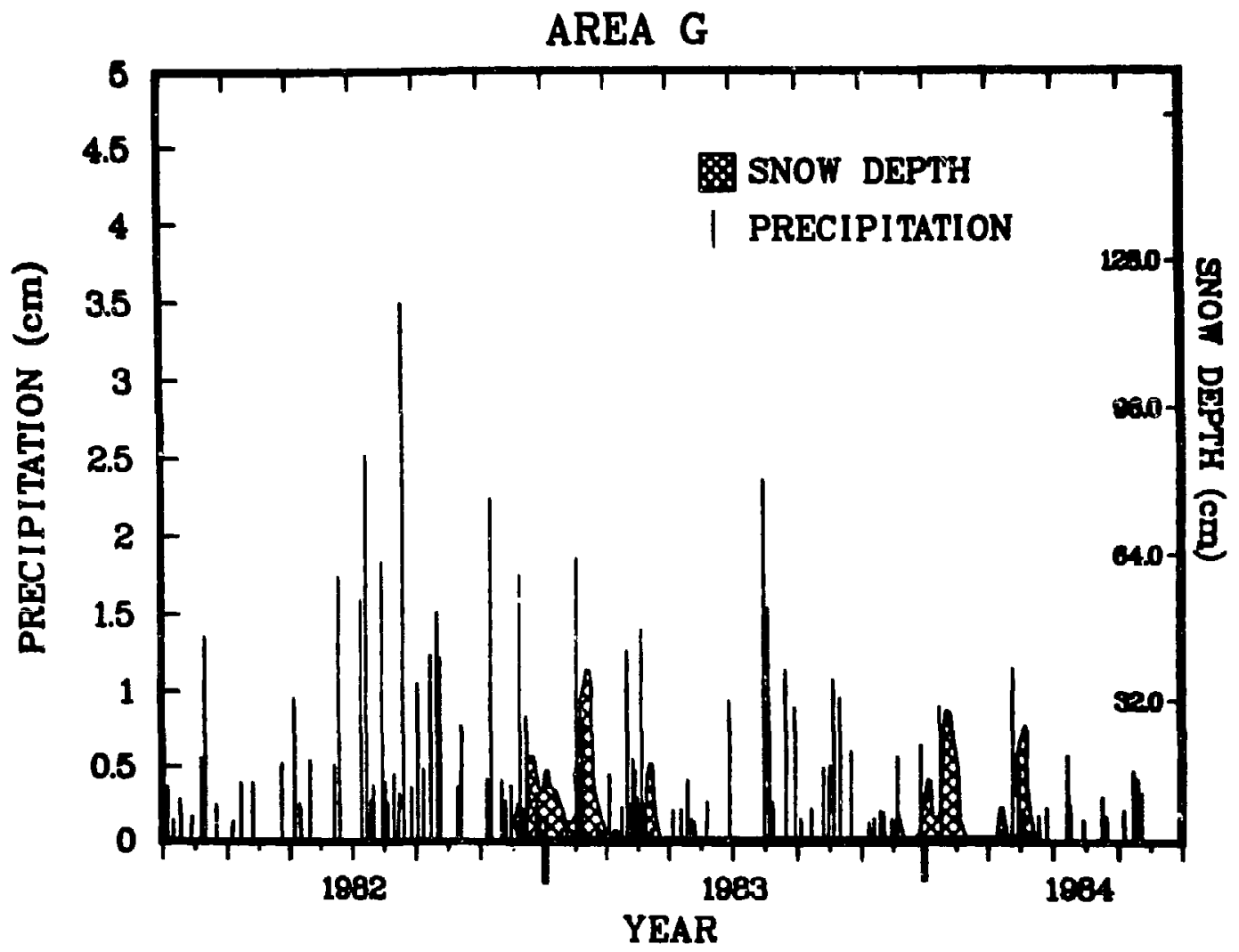

Fig. 13. Daily precipitation and snow cover on the Area G biointrusion barrier study plots.

TABLE X

MONTHLY PRECIPITATION TOTALS (CM) FOR THE AREA G INTERMEDIATE-SCALE BIOINTRUSION STUDY

\begin{tabular}{|c|c|c|c|}
\hline Month & 1982 & 1983 & 1984 \\
\hline January & 0.90 & 2.37 & 0.79 \\
\hline February & 2.20 & 1.49 & 0.12 \\
\hline March & 0.97 & 4.05 & 3.17 \\
\hline April & 0.56 & 0.37 & 0.75 \\
\hline May & 1.90 & 1.36 & 0.91 \\
\hline June & 2.34 & 1.45 & 0.58 \\
\hline July & 7.84 & 4.10 & - \\
\hline August & 6.72 & 6.54 & - \\
\hline September & 6.48 & 1.58 & - \\
\hline October & 1.24 & 3.12 & - \\
\hline November & 5.41 & 0.89 & - \\
\hline December & 4.22 & 1.69 & - \\
\hline Total & 40.78 & 29.0 & $6.32^{\mathrm{a}}$ \\
\hline
\end{tabular}

'Total from January thrnugh June. 
essentially zero and evaporation from the soil surface was greatly raduced, percolation did occur and was followed by commensurate rise in backfill moisture.

In general, the rock intrusion barrier cap designs allowed at least as much or more water to reach the backfill than did the crushed tuff barrier design, likely reflecting the decreased capacity of the rock to store water. Recall that the $15 \mathrm{~cm}$ of topsoil overlying all the plots could theoretically store a maximum of about $6 \mathrm{~cm}$ of water (saturation of the topsoil is reached at about $40 \%$ moisture by volume).

The moisture content of backfill beneath the rock barrier designs responded rapidly to water percolating out of the topsoil because of the low storage capacity and high hydraulic conductivity of the rock material, while changes in the water content of backfill beneath the crushed tuff cap design were relatively insensitive to precipitation inputs because of the added storage capacity and lower hydraulic conductivity of the crushed tuff barrier material. Although seasonal patterns in the moisture content of the backfill under all cap designs were evident, the overall pattern suggests one of increasing moisture with time. In general, backfill moisture in all plots had increased by $2-4 \%$ by volume over that measured at the beginning of the study. However, further monitoring of backfill moisture would be required to establish the validity of that trend. It is apparent that $15 \mathrm{~cm}$ of topsoil dc as not provide sufficient water-holding capacity to prevent movement of water through the biobarriers at Area $G$ even when the barrier consists of $1 \mathrm{~m}$ of crushed tuff.

\section{B. Caissons $C$ and $D$}

1. Methods and Materials. Based upon the results from the small-scale lysimeter siddy, the ongoing Area G study, and computer modeling studies 
another intermediate-scale biointrusion experiment was initiated in mid-1982 to determine the performance and operating limits of an improved soil-gravel/cobble intrusion barrier design compared to a conventional soil/crushed tuff when stressed with enhanced precipitation. The monitoring experiment was conducted in the $3-\times 6-m$ caissons at the Los Alamos Experimental Engineered Test Facility (DePoorter, 1981) and was designed to evaluate the effectiveness of the two trench cap configurations in preventing plant root intrusion and in controlling percolation. The limits of trench cap performance were evaluated with respect to previpitation input by simulating upper limit and extreme climate regimes through supplemental irrigation of the plots.

Two caissons were used in this multipurpose study involving water and solute transport as well as biointrusion barrier cap desigris (DePoorter, 1981). The intrusion barrier cap designs were placed over the top of about 390 $\mathrm{cm}$ of compacted crushed tuff backfill (Fig. 14). The cap and backfill

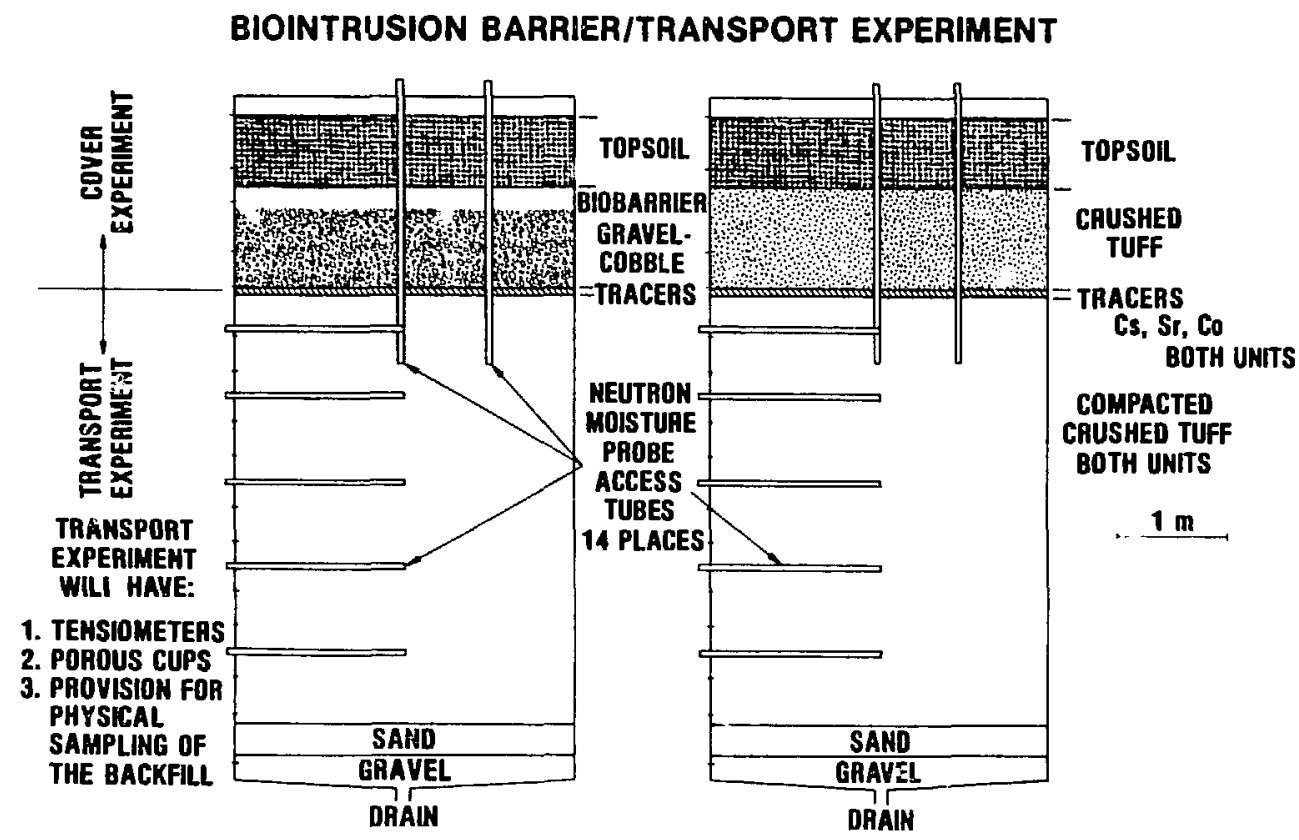

Fig. 14. Design of intermediate-scale biointrusion study conducted in $3 \times 6 \mathrm{~m}$ caissons at the Los Alamos Experimental Engineered Test Facility. 
interface was contaminated with $416 \mathrm{~g}$ of $\mathrm{CoCl}, 32 \mathrm{~kg}$ of $\mathrm{Sr}\left(\mathrm{NO}_{3}\right)_{2} \times 4 \mathrm{H}_{2} \mathrm{O}$ and $800 \mathrm{~g}$ of $\mathrm{CsCl}$. The cesium, applied at a rate of about $190 \mathrm{~g} / \mathrm{m}^{2}$, was used to evaluate plant root intrusion through the two cap designs.

The cap design in Caisson $C$ consisted of 100-cm compacted crushed tuff covered with $60 \mathrm{~cm}$ of Hackroy series topsoil (Fig. 14). The cap in Caisson D consisted of $75 \mathrm{~cm}$ of 12 - to 18 -cm-diameter washed cobble covered with $25 \mathrm{~cm}$ of 2-cm-diameter washed gravel. A 60-cm layer of the Hackroy topsoil over the gravel completed the cap profile (Fig. 15).

A 60-cm topsoil depth was selected based upon computer simulations with a water balance model called CREAMS (Chemical, Runoff, Erosion, In Agricultural Management Systems; Knisel, 1980) using a 20-year climate record at Los Alamos. Model calculations (Nyhan and Lane, 1982) showed that the storage capacity of a $60 \mathrm{~cm}$ clay/loam topsoil was sufficient to reduce percolation

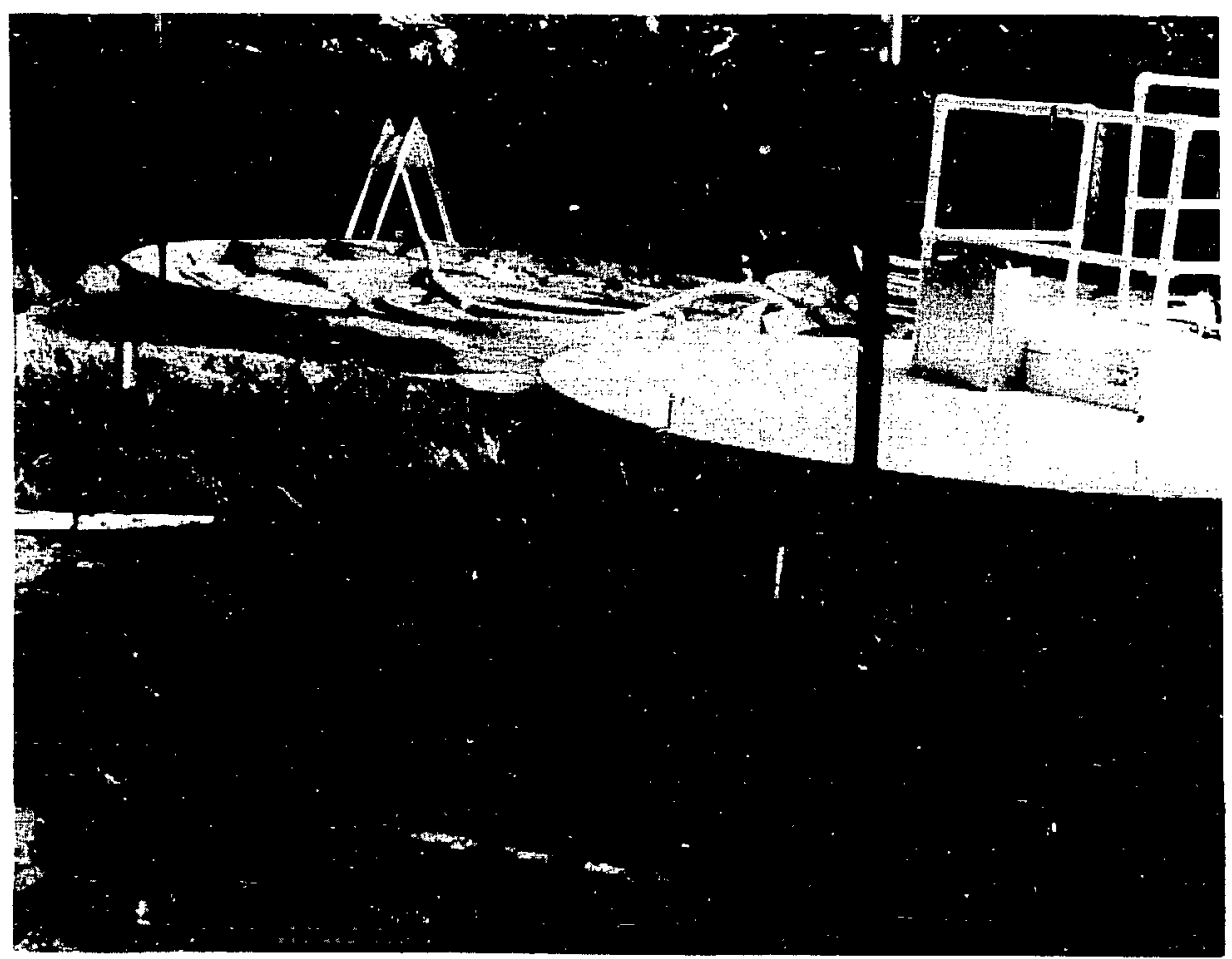

Fig. 15 Caissons C (foreground) and D (background) used in biointrusion barrier study. Neutron access tubes and alfalfa cover is shown on the surface of the caissons. 
through the topsoil to less than 15\% of that estimated for the 15-cm topsoil cover used in the Area G experiment. (Fig. 16).

The surface of both caissons was seeded to barley (Hordeum vulgare) on May 28, 1982, and treated with 0-46-0 fertilizer and a thin layer of peat moss to facilitate seed germination. Barley covered the plots until June 8, 1983, when a new cover of alfalfa (Medicago sativa) was established for the duration of the study (Fig. 15).

Access tubes installed during plot construction were used to measure changes in the volumetric water content of topsoil and the crushed tuff backfill underlying the respective intrusion barriers (Fig. 14) using a Campbell Pacific Model 503 moisture gauge. Plant samples (4/caisson/sampling date) were also periodically collected and analyzed for cesium content using neutron activation analysis (Gladney, et al., 1984).

CREAMS 20 YEAR SIMULATION

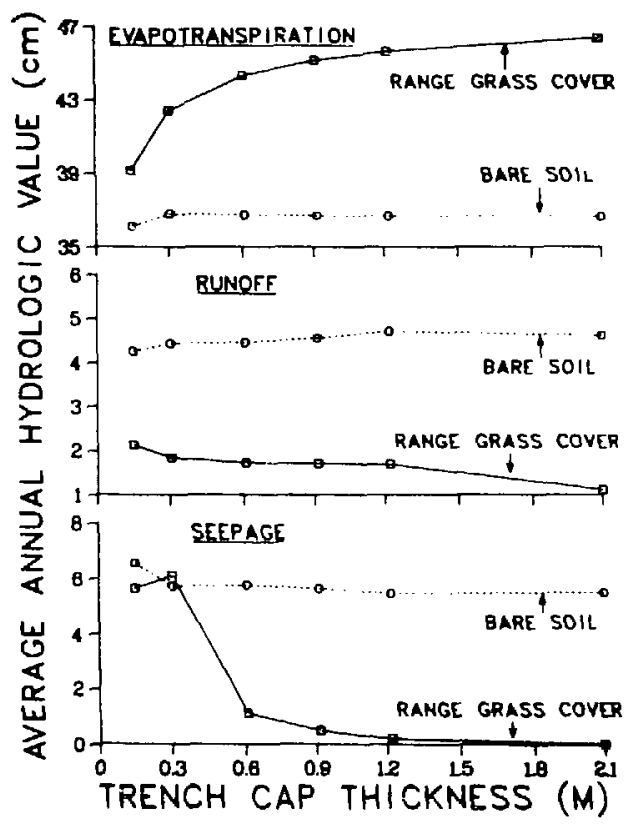

Fig. 16. Predicted average annual hydraulic values as a function of trench cap thickness at Los Alamos. Calculations based on a clay loam Heckroy series topsoil and a 20-year (1951-1970) precipitation record at Los Alamos, New Mexico. 
Supplemental moisture, in addition to natural precipitation, was added to bring the annual precipitation to within the range of $75-100 \mathrm{~cm}$. Annual precipitation of that magnitude at Los Alamos has a probability of occurring about once every 100 years (Abeele, 1980). As mentiond before, the relatively large amount of precipitation added to the plots was an attempt to determine performance at a realistic climatic extreme for a semiarid environment. Secondarily, the large amount of precipitation added to the plots was necessary in order to keep the plant cover alive. Essentially all of the water added to the plots infiltrated into the soil surface since runoff was prevented by the lip of the caissons.

2. Results. During a 17-month observation period spanning two gro ing seasons, a total of 24 of the 76 samples from the soil/tuff cap design contained elevated cesium (Table B-I). Corresponding figures for the soil/rock cap design were 18 out of 76 samples for a root intrusion frequency of about 25-30\% for both designs. Maximum concentrations of cesium observed in plant samples from botı cap design's were about 400 times the 1-ppm background level.

Although the frequency of root penetrations to the cesium was about equal for both cap designs, the cesium concentrations in plants from the soil/rock design averaged about $1 / 3$ of those for the soil/tuff design (Table XI). The overall mean concentration of about 27 ppm cesium in plants from caisson $C$ was significantly higher $(p<0.05)$ than the 11 -ppm average for caisson 0 reflecting the same general pattern of cesium uptake observed in the Area $G$ study, where concentration in plants from the soil/rock designs averaged 3-9 times less than those from the soil/tuff design. The lower cesium concentracions observed in samples from the soil/tuff designs likely reflects 
the inhibiting effect of the rock barrier on the mass of roots that come into contact with the cesium tracer.

\begin{tabular}{|c|c|c|c|}
\hline \multicolumn{4}{|c|}{ TABLE XI } \\
\hline \multicolumn{4}{|c|}{$\begin{array}{l}\text { AVERAGE }(n=4) \text { CESILM CONCENTRATIONS } \\
\text { AND STANDARD DEVIATIONS (PPM) IN VEGETATION } \\
\text { FROM CAISSONC (TOPSOIL-CRLSHED TLFF) AND } \\
\text { CAISSON D (TOPSOIL-GRA VEL/COBBLE) } \\
\text { TRENCH COVER INTRL'SION BARRIER DESIGNS }\end{array}$} \\
\hline \multirow{2}{*}{$\begin{array}{l}\text { Sampling } \\
\text { Date }\end{array}$} & \multirow{2}{*}{$\begin{array}{l}\text { Plant } \\
\text { Coner }\end{array}$} & \multicolumn{2}{|c|}{ Cap Design } \\
\hline & & Soit-Tuft & Soil-Gravel/Cobble \\
\hline June 22.1982 & $\overline{\text { Barle? }}$ & $\overline{0.2(0.08)}$ & $0.45(0.37)$ \\
\hline July 2.1982 & Barle! & $0.10(0)$ & $0.10(0)$ \\
\hline Jul: 12.1982 & Barle! & $0.07(0.04)$ & $0.0 n 10.051$ \\
\hline July 22. 1982 & Barles: & $0.15(0.06)$ & 0.2010 .141 \\
\hline August 2. 1482 & Barle! & $0.18(0.05)$ & $0.65(0.77)$ \\
\hline Augus1 1:. 1982 & Barle: & $(2+1+8)^{\circ}$ & $\therefore \cdots$ \\
\hline tugust 23.1982 & Barle! & $1.1(0.37)$ & $101 \pi$ \\
\hline Scptember 2. 1982 & Barle! & $\because 2+1$ & $1,1.2$ \\
\hline Seplember ! 1, 1482 & Barle? & $0.45(0.63)$ & 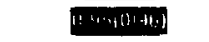 \\
\hline September 24. 1982 & Burle? & an & and \\
\hline October 5. 1982 & Barle: & 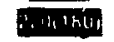 & Pan \\
\hline Oclober 15, 198? & Barle: & abilil & i. in \\
\hline Oclober 25. 1982 & Barle! & [inildin & 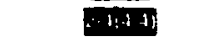 \\
\hline April 14. 1983 & Barley" & (4) & $0.37(0.15)$ \\
\hline June 8. 1983 & Barles ${ }^{2}$ & 1.1 .28 & $0.17(0.07)$ \\
\hline Jul! 27.1483 & HIfalía & 0.8410 .541 & 0.5410 .111 \\
\hline August 29.1983 & Alfallis & $0.09(0.03)$ & $0.10(0.01)$ \\
\hline Ncrober + 1983 & Alfalfa & $0.87(0.37)$ & $0.98(0.64)$ \\
\hline Norember 8.1983 & flifalía & $0.54(0.21)$ & $1 \log 621$ \\
\hline Overall mean & & 27 & 11 \\
\hline Standard devation & & 80 & 54 \\
\hline Range & & $0.1-380$ & $0.03-450$ \\
\hline
\end{tabular}

The failure of both trench cap designs in preventing root intrusion was anticipated because of the large amount of water added to each plot over the two-year study. The total precipitation added to the plots during the 20-month observation period was $178 \mathrm{~cm}$ of which $75 \mathrm{~cm}$ was natural precipitation. Recall that we were attempting to simulate $z$ water year with about 100-year return period in Grder to determine the response of the two designs to excess soil moisture. The frequent wetting and drying of the topsoil on both caps was expected to encourage root intrusion into the crushed 
tuff backfill under the caps where soil moisture was relatively high and less variable than in the topsoil.

Although root intrusion through both of the $160-\mathrm{cm}$ trench cap designs did occur, the frequency of intrusion was surprisingly low (i.e., <30\% of the samples had elevated cesium concentrations). However, the low incidence of root intrusion during the latter part of the study when alfalfa was seeded into the plots may have been due to the small root systems that were likely associaced with the new alfalfs cover.

Volumetric water content of the topsoil (Fig. 17) and the tuff backfill (Fig. 18) underlying the two cap designs was quite variable with soil depth and time. As would be expected, the moisture content of topsoil varied by a factor of 4 (Fig. 17) over the course of the study, while backfill moisture only varied by a factor of 1.6 ( $F i g .18$ ). Major changes in the water content

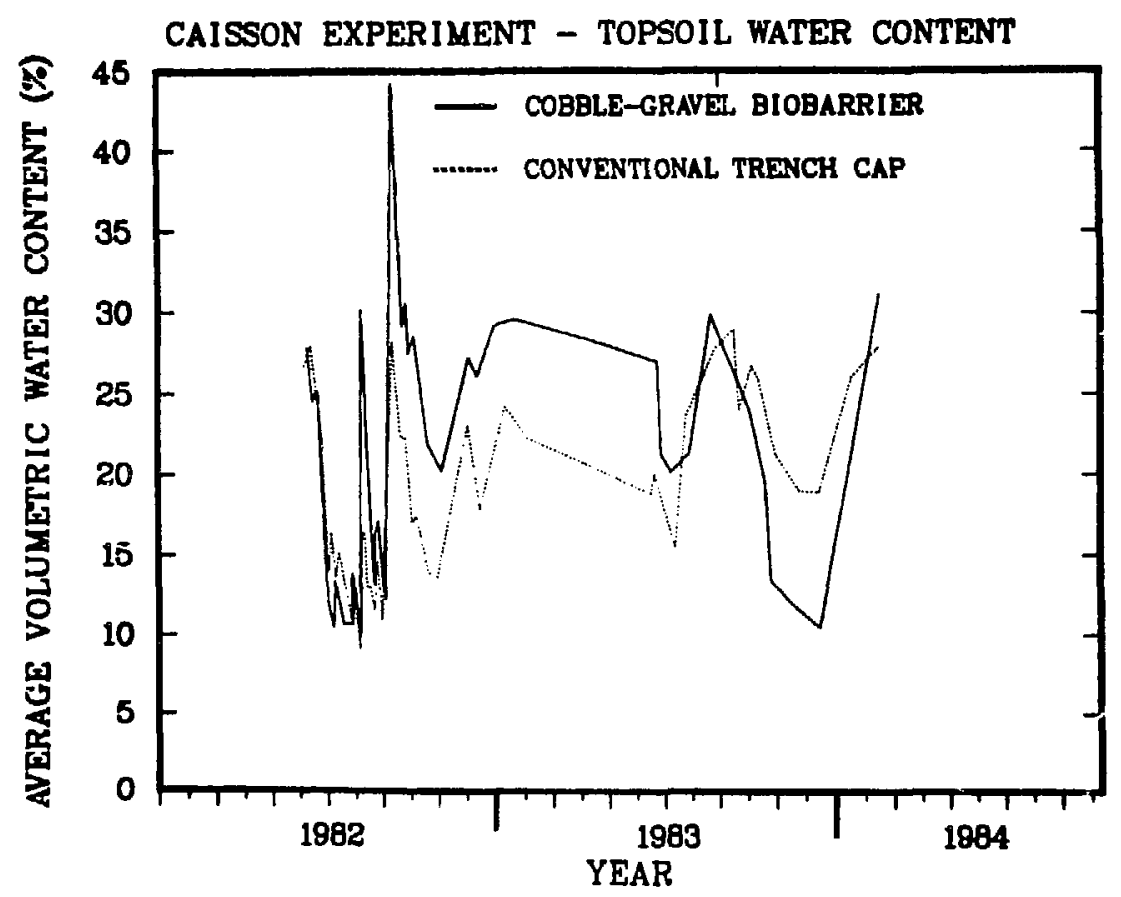

Fig. 17. Volumetric water content of the 60-cm topsoil layer covering the biointrusion barriers in Caissons $C$ and $D$. 


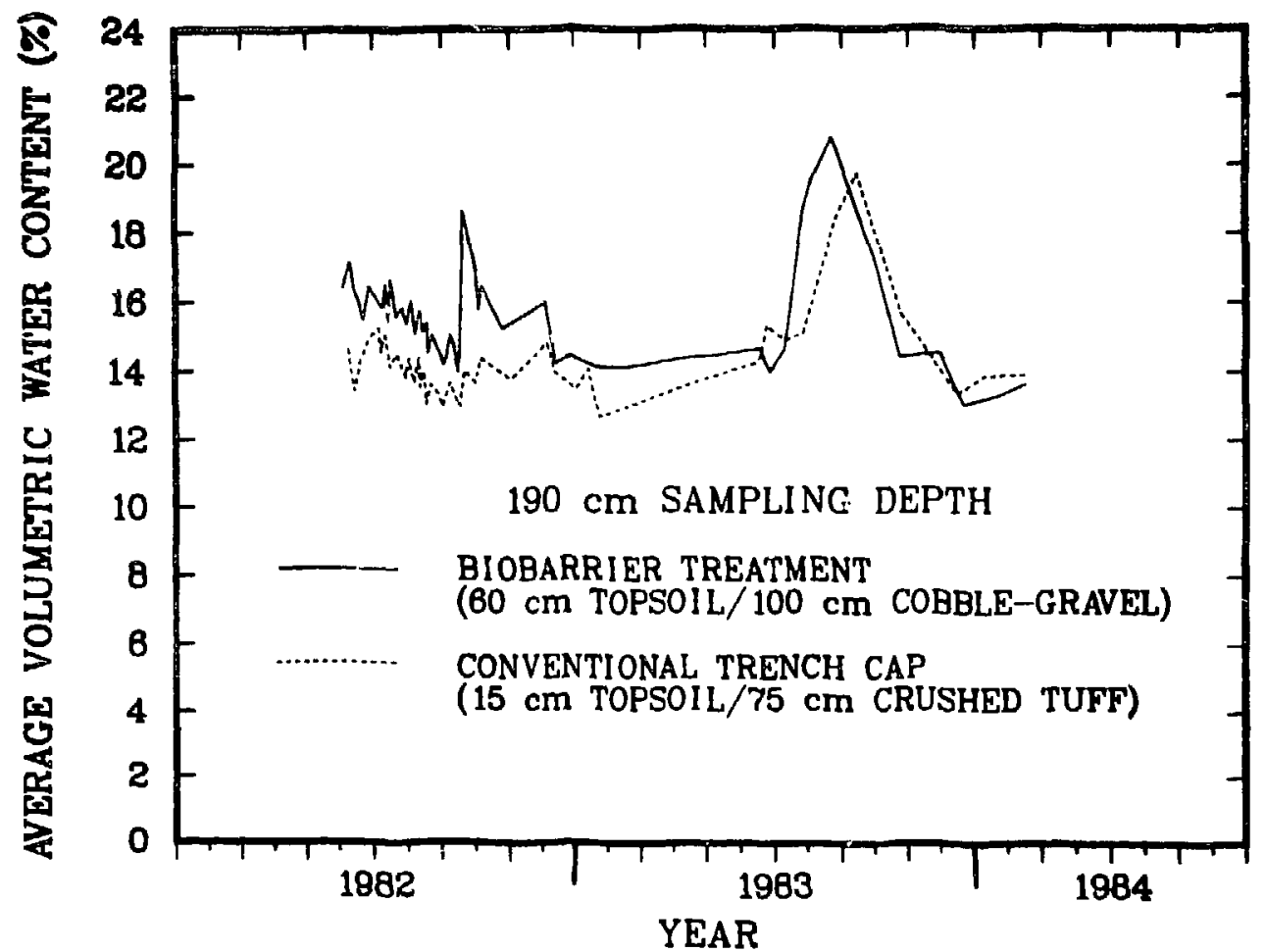

Fig. 18. Volumetric water content of the crushed tuff backfill under the biointrusion barriers in Caissons $C$ and $D$.

of soil with time were primarily associated with additions of supplemental water to the plots, to snowmelt during the winter (Fig. 19), and to periods when soil moisture was influenced by evapotranspiration. The very strong influence of plants in controlling soil moisture was readily apparent from the data for topsoil (Fig. 17). For example, in June and July of 1982, when barley covered the plots, soil moisture in both plots steadily decreased from a value of about $20 \%$ by volume to about $9 \%$, despite the addition of about 25 $\mathrm{cm}$ (10 inches) of water.

Because the growing season was well under way when the experiment was begun in 1982, the decision was made to add increasingly large pulses of water to the plots in order to determine the performance limits of the two cap 


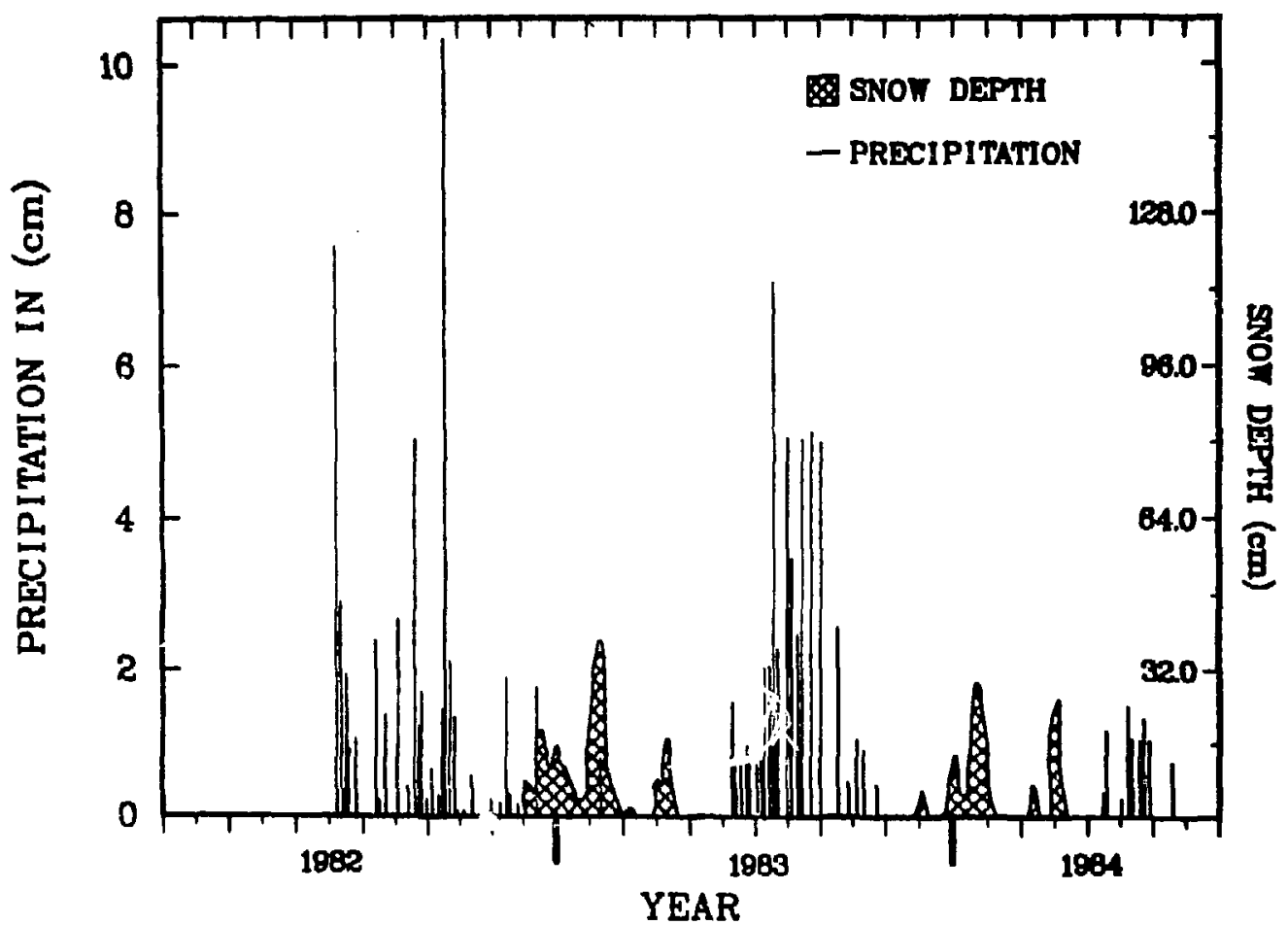

Fig. 19. Daily precipitation and snow cover on the Caisson $C$ and $D$ biointrusion barrier study plots.

designs for preventing percolation when the plant cover was actively transpiring. On August 9, 1982, a 5-cm (2 inch) pulse of water was added to each caisson by flood irrigation (Fig. 19). Based on calculations (Table B-II), a 5-cm rainfall depth over a 60-minute period at Los Alamos has a probability of occurring once every 100 years.

Volumetric water content of topsoil (Fig. 17) as measured at midway into the $60-\mathrm{cm}$ profile, quickly increased by factors of 2 to 4 in both caissons. The largest increase (from about 8 to about 30\% by volume) occurred in the topsoil over the rock barrier design while a smaller increase (from 8 to 16\% by volume) was observed for the tuff barrier system. The moisture content of topsoil then rapidly decreased to the levels measured prior to the addition of the $5 \mathrm{~cm}$ of water primarily due to evapotranspiration losses of soil water. 
No response of backfill moisture was observed following the 5-cm water addition indicating that water did not percolate through either cap design. Thus, an acute input of moisture, approximating a short duration rainstorm with a 100 year return period at Los Alamos, resulted in no percolation into the backfill underlying either trench cap design when the plant cover was actively transpiring.

A second $10-\mathrm{cm}$ pulse of water was added to both caissons on September 17 , 1982, late in the growing season to further extend knowledge of operating limits of the two designs with respect to moisture. Within 24 hours of adding the water, an additional $2.2 \mathrm{~cm}$ of natural rain fell on the plots bringing the 24-hour total water input to $12.2 \mathrm{~cm}$. Based upon data presented in Table B-II, a $12.2 \mathrm{~cm}$ rainfall over a 24-hour period at Los Alamos was estimated to have a minimum return period of 1,000 years.

Topsoil moisture in both plots responded dramatically to the water input (Fig. 17) as would be expected, and then decreased rapidiy over the next 2-3 weeks as evapotranspiration and percolation depleted the moisture.

Percolation through the cap into the underlying tuff backfill also occurred (Fig. 8) and was especially apparent for the soil/rock barrier design where a $36 \%$ increase in moisture was measured (i.e., from $4 \%$ to $19 \%$ by volume). The moisture content of backfill under the tuff barrier also increased but did so slowly and by a smaller amount. The differences in backfill moisture dynamics between cap designs again reflect the effect of the differences in water storage capacity and the associated hydraulic conductivities of the barrier materials.

A final supplemental addition of water was made throughout the growing season of 1983 to examine the influence of a chronic input of water on topsoil and backfill moisture when the cover crop ( $\mathrm{alfalfa}$ ) had a very high water 
requirement. Beginning about June 1, 1983, and extending through September 1983, about $95 \mathrm{~cm}$ of water, of which $18 \mathrm{~cm}$ was natural rainfall, was added in 1- to 5-cm pulses applied every 3-5 days.

During June through July, when $37 \mathrm{~cm}$ (14 inches) of water was added to the caissons, primarily as pulses less than $2 \mathrm{~cm}$ (Fig. 19), moisture in the topsoil of both plots decreased steadily reflecting the large potential of evapotranspiration for removing soil water. Not until late July, when the supplemental water was increased to $5-\mathrm{cm}$ pulses, did topsoil moisture begin to increase (Fig. 17).

The addition of about $58 \mathrm{~cm}$ (about 23 inches) of water during August and September doubled topsoil moisture (Fig. 17) and resulted in percolation or water to the backfill underlying the two cap designs (Fig. 18). On Septernber 11, 1983, the soil/rock covered backfill began producing percolate out of the bottom of Caisson D. The percolation continued until March 1984, producing a total of $1474 \mathrm{~L}$ or, based on the 300-cm diameter of the caisson, a 20-cm depth of water.

Caisson C (tuff intrusion barrier) began producing percolate 16 days later on September 27, and produced $986 \mathrm{~L}$ of water (or a 13.5-cm depth) through March 1984. Overall, then, about one-third less percolation occurred through the 600-cm trench cap/backfill profile that through the soil/rock desigr.

Although snowmelt (Fig. 19) produced observable changes in topsoil moisture during the winters of 1982-1983 and 1983-1984, the water storage capacity of the topsoil was apparently sufficient to prevent percolation into the backfill (Fig. 18). Recall that the 15-cm topsoil depths used on the Aree $G$ plots did not provide adequate storage capability for water, and that snowmelt was the majcr source of water percolating beneath the trench cap designs under natural precipitation regimes. In contrast, the 60-cm topsoil 
depths used on the Cajscons $C$ and $D$ study appeared to be adequate for storing the snowmelt occurring during the study.

An approximate mass valance of water added to the caissons can be estimated based on measured moisture additions, the volume of percolate produced, and the volume of water in storage as determined at several levels in the profile with the neutron moisture gauge. The volume of water in storage can t: determined as follows:

$$
V=\theta_{\gamma} C_{i} / K \text {, }
$$

where $\underline{V}$ is the volume of water in storage in liters, $\theta_{\gamma}$ is the average (over depth) volumetric water content (fractional number), $\underline{D}$ is the depth of soil profile in cn, $\underline{A}$ is the area of the soil profile in $\mathrm{cm}^{2}$, and $\underline{k}$ is $1000 \mathrm{~cm}^{3} / \mathrm{L}$. As of February 1, 1984, a total of $181 \mathrm{~cm}$ of water (natural plus supplemental) was added to Caissons $C$ and D. As indicatad, $20 \mathrm{~cm}$ and $13.5 \mathrm{~cm}$ had percolated out of the bottom of Caissons $C$ and $D$, respectively, by this date. Based on Equation (1), about $79 \mathrm{~cm}$ of water was in storage in Caisson c and $75 \mathrm{~cm}$ in Caisson D at the beginning of the experiment on June 11, 1982, and also at the end of the experiment on February 1, 1984, resulting in no net change in moisture in storage. By subtraction, then, roughly $165 \mathrm{~cm}$, or about 90\% of the $181 \mathrm{~cm}$ total water added to the plots was lost to evapotranspiration over the course of the study, 13-20 cm had percolated out of the caissons, and net change in moisture storage was zero. Had natural precipitation regimes been used during the study, essentially 100\% of the water added to the plots would have been evaporated and/or transpired back to the atmosphere.

An interescing pattern in the topsoil moisture data (Fig. 17) deserves special consideration because of the possible ramifications in subsurface 
water management. Note from $\tilde{F}$ ig. 17 that the moisture content of topsoil over the rock barrier often measured several per cent by volume higher than did the topsoil moisture over the tuff barrier. Assuming that the properties of the topsoil and plant cover growing on the plots were the same, as we believe they were, the data suggest that the soil/rock barrier design also likely serves as a capillary barrier preventing downward (and upward) flow of water under unsaturated flow conditions.

The capillary barrier effect of two layered materials, such as the topsoil over rock, derives from the differences in particle or grain size of the materials and the attendant differences in their ability to retain water. A relatively fine-textured soil, such as the clay/loam Hackroy series topsoil on Caissons $C$ and $D$, retains water much more tenaciously than a coarser-grained material such as gravel or cobble. If a relatively sharp interface between the soil and rock can be maintained, then water moving downward and through the soil will be impeded at this interface until the soil becomes saturated (Abeele, 1984b). Upon saturation of the topsoil, water will then break through the interface and enter the rock. Drainage through the rock will be rapid due to the lack of water storage capacity of this material as is abvious from the Area $G$ and Caissons $C$ and $D$ backfill moisture data.

In contrast, water moving through a topsoil over tuff profile will not be greatly impeded because of the similarity in particle size between the two materials. In order for a layered profile to work as a capillary barrier, the differences in matric potential between the two materials must be significant. The theory of capillary barrier systems and experimental data on the performance of a soil/rock capillary barrier are discussed further elsewhere (Abeele, 1984b). 
As a consequence of the preceding discussion, the anticipated effect of a capillary barrier, such as the soil/rock intrusion barrier, would be a higher soil moisture content of the topsoil compared with that measured in the topsoil of a soil/tuff cap design that can more freely drain. That assumes, of course, that moisture inputs, topsoil characteristics, and plant cover are identical among cap designs and that the physical and hydraulic properties of tuff are similar to that of topsoil.

The obvious benefit of restricting water to the topsoil is that the water is available to plant roots and, therefore, can be removed by evapotranspiration. As mentioned before, evapotranspiration lcsses of soil water are highly beneficial in that they reduce and/or eliminate percolation through the trench cap and into subsurface regions.

It is clear from the first year's data, shown in Fig. 17, that topsoil moisture over the rock barrier consiscently averaged higher than the topsoil over the tuff barrier. However, during the second year, when alfalfa was seeded on the plots and very large amounts of water were added, the pattern changed. Although preliminary data suggest that a soil/rock intrusion barrier cap design may also function as a capillary barrier, further research is needed to determine operational limits.

The major rindings of the Caissons $C$ and $D$ study, where moisture regimes simulated upper extremes, can be summarized as follows:

o Root intrusion occurred through both trench cap designs but concentrations of the cesium tracer in plants from the soil/rock design averaged about one-third (significant at $p<0.05$ ) of those measured in samples from the soil/tuff cap design.

- A 5-cm acute pulse of artificial precipitation, roughiy approximating a 1-in-100-year storm, produced no measurable change in backfill moisture 
under either cap design when the plant cover was actively transpiring.

- A 12.2-cm pulse of artificial and natural precipitaion applied over a 24-hour period during the summer growing season, and simulating a storm with a minimum return period of 1000 years, produced measurable changes in backfill moisture under both cap designs. Percolation into the backfill occurred as a sharp pulse of water under the soil/rock design and changed graduall over a longer period of time under the soil/tuff design.

o A chronic precipitation input totaling $95 \mathrm{~cm}$ over a 4-month period during the summer growing season produced large changes in backfill moisture and resulted in percolate being produced out of the bottom of the 600-cm-deep cap and backfill profiles.

o The soil/rock cap treatment produced about 33\% more percolate than the soil/tuff treatment under upper extreme precipitation regimes.

o The soil/rock cap design, under more normal precipitation regimes, may function as a capillary barrier as well as a biological intrusion barrier.

- Major topsoil water recharge occurs during winter as a result of snowmelt and the lack of transpiring vegetation.

o Based on calculations and data, of the $178-\mathrm{cm}$ precipitation added to the plots from June 1982 to February 1984, about 10\% percolated through the entire 600-cm profiles, about 40\% was temporarily stored as soil moisture, and over $90 \%$ was evaporated and/or transpired back to the at inosphere.

Based upon the results of the small- and intermediate-scale biointrusion studies concerning optimum barrier/topsoil configurations and failure modes under different precipitation regimes, a final study was initiated to compare 
the soil/rock trench cap design with a conventional de ign under conditions of natural precipitation, a native grass cover, and little or no maintenance. The following section describes the biointrusion barrier on Area $B$.

\subsection{Field Scale Studies - Area B}

A. Methods and Materials. Area B, a Los Alamos low-level radioactive waste disposal site, was closed in 1947 when waste operations were moved to another location ( $F$ ig. 20). In 1982, as part of scheduled remedial action a a 0.61-ha ( $1.64 \mathrm{a}$ ) portion of Area B, waste operations presented us with the opportunity to field test our soil/rock trench cap design along with a conventional design that was to be used at Area B as a part of the remedial action.

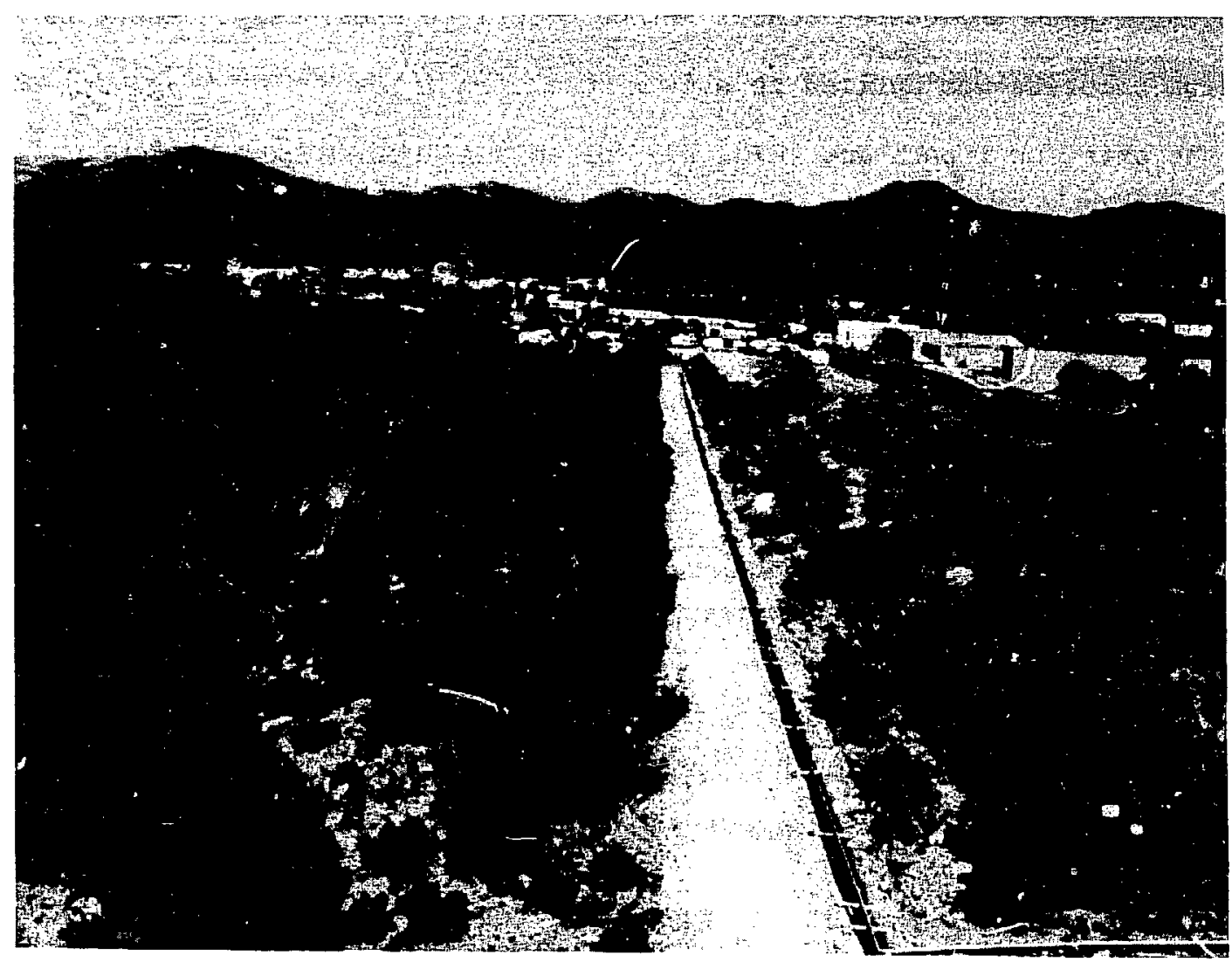

Fig. 20. Area B low-level waste site (fenced area) prior to removal of tree and shrub cover. Area B was decommissioned in 1947 and received a new cover in 1982. 
The Area B study addressed two questions:

1. Does the cabble/gravel biointrusion barrier cap design perform any better than the soil/crushed tuff cap at field scale under natural precipitation regimes and native grass cover?

2. Does the cobble/gravel trench cap design act as a capillary barrier to percolating water under field conditions?

The remedial action performed by waste operations consisted of applying a new trench cap on top of the existing cap at Area $B$ in order to cover radionuclide contamination present on the ground surface. All tree and large shrub cover (Fig. 20) was removed prior to constructing the new cap.

Two plot areas were established on Area B as shown in Figs. 21 and 22 . The performance of the two designs in limiting plant root intrusion was evaluated with the cesium tracer method described previously. About $16 \mathrm{~kg}$ of cesium chloride was applied to a 6- $\times$ 40-m area in each plot (Fig. 21) on top of the existing trench cap (Fig. 23) for an application rate of $240 \mathrm{~g} / \mathrm{m}^{2}$. After the tracer was applied, a $15-\mathrm{cm}$ layer of uncontaminated soil was spread

$1 \mathrm{~cm}=10 \mathrm{~m}$

AREA B - LOW-LEVEL WASTE STE BID-DTRUSION STUDY (SITE DECOBgBaSSSIOHED in 1947)
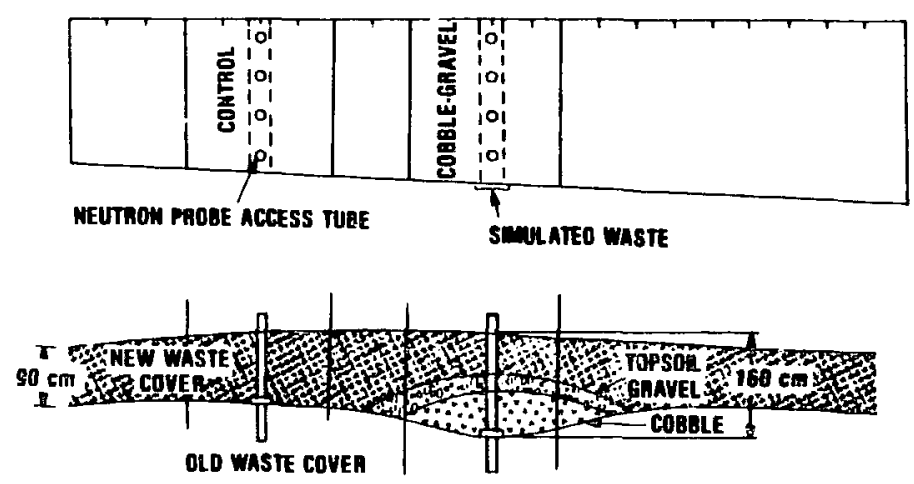

Fig. 21. Schematic of plot configurations for the Area B biointrusion barrier study initiated in 1982. Control treatment represented the conventional cap design constructed on Area B. The intrusion barrier design consisted of topsoil over layered rock. 


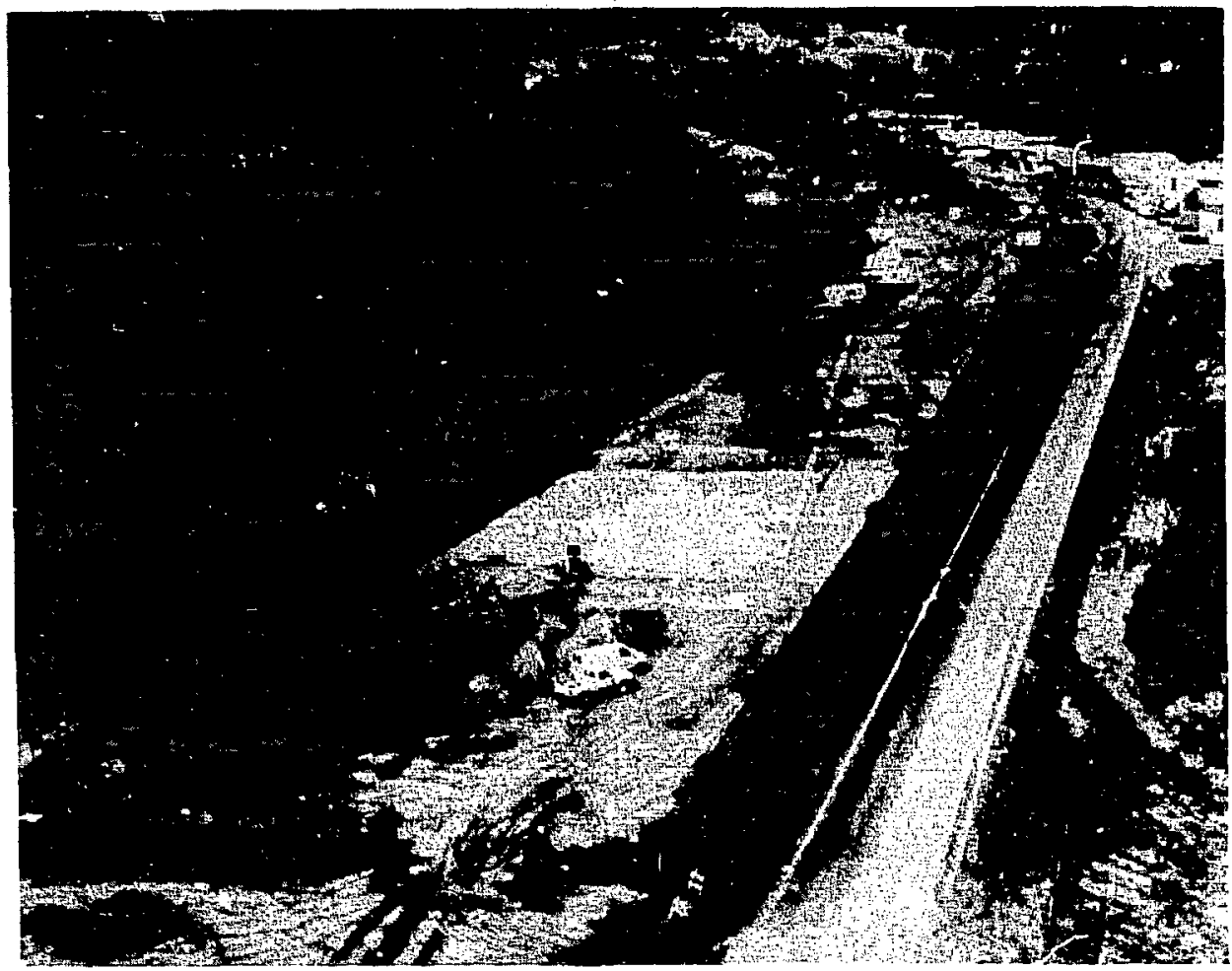

Fig. 22. Construction of biointrusion barrier plots at Area B in 1982 . The cobble/gravel barrier design is shown under construction in the center of the photo. The conventional cap design was located in the background under the stockpiled topsoil.

over the entire area to prevent cross contamination by the earth-moving machinery.

Neutron access tubes were installed at four locations along the slope in each plot (Fig. 21). The tubes extended $60 \mathrm{~cm}$ into the old trench cap to provide access for measuring the moisture content of soil underlying the new caps.

The cap profile in the control plot consisted of about $75 \mathrm{~cm}$ of crushed tuff covered with $15 \mathrm{~cm}$ of topsoil. The soil/rock cap design (Fig. 24) consisted of $75 \mathrm{~cm}$ of 10 - to 30-cm-diameter cobble covered with $25 \mathrm{~cm}$ of 2-cm 


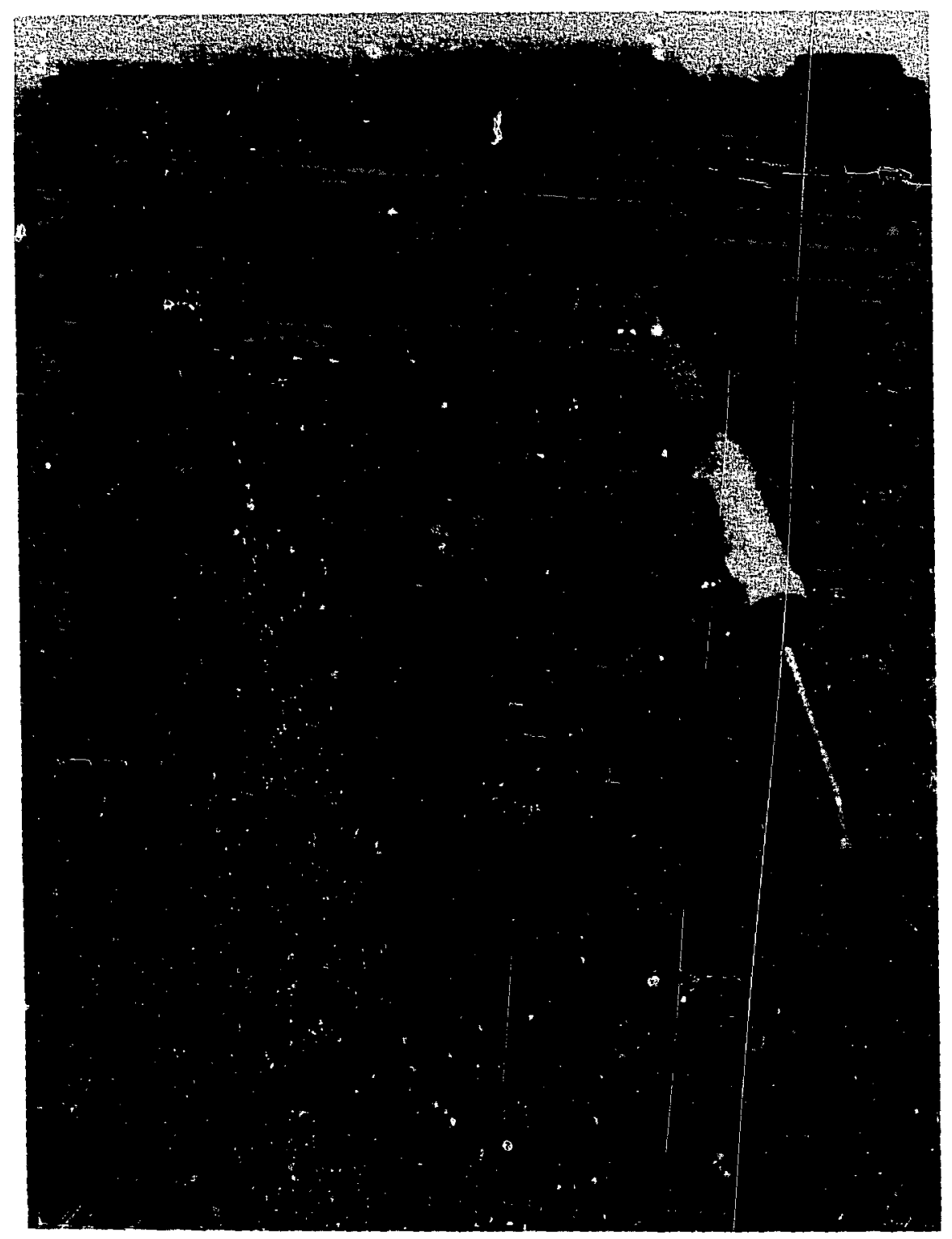

Fig. 23. Application of cesium chloride to old trench cap surface at Area $B$ to serve as a simulated waste for evaluating plant root intrusion through the new trench cap designs.

gravel all covered with $60 \mathrm{~cm}$ of Hackroy series clayiloam topsoil. Buth plots had a surface slope of about 2-30 to allow for some surface runoff.

The surface of the entire area was seeded with a mixture of native grasses (Table VII) and covered with straw mulch to minimize erosion during establishment of the plant cover. Because the plot was constructed late in 


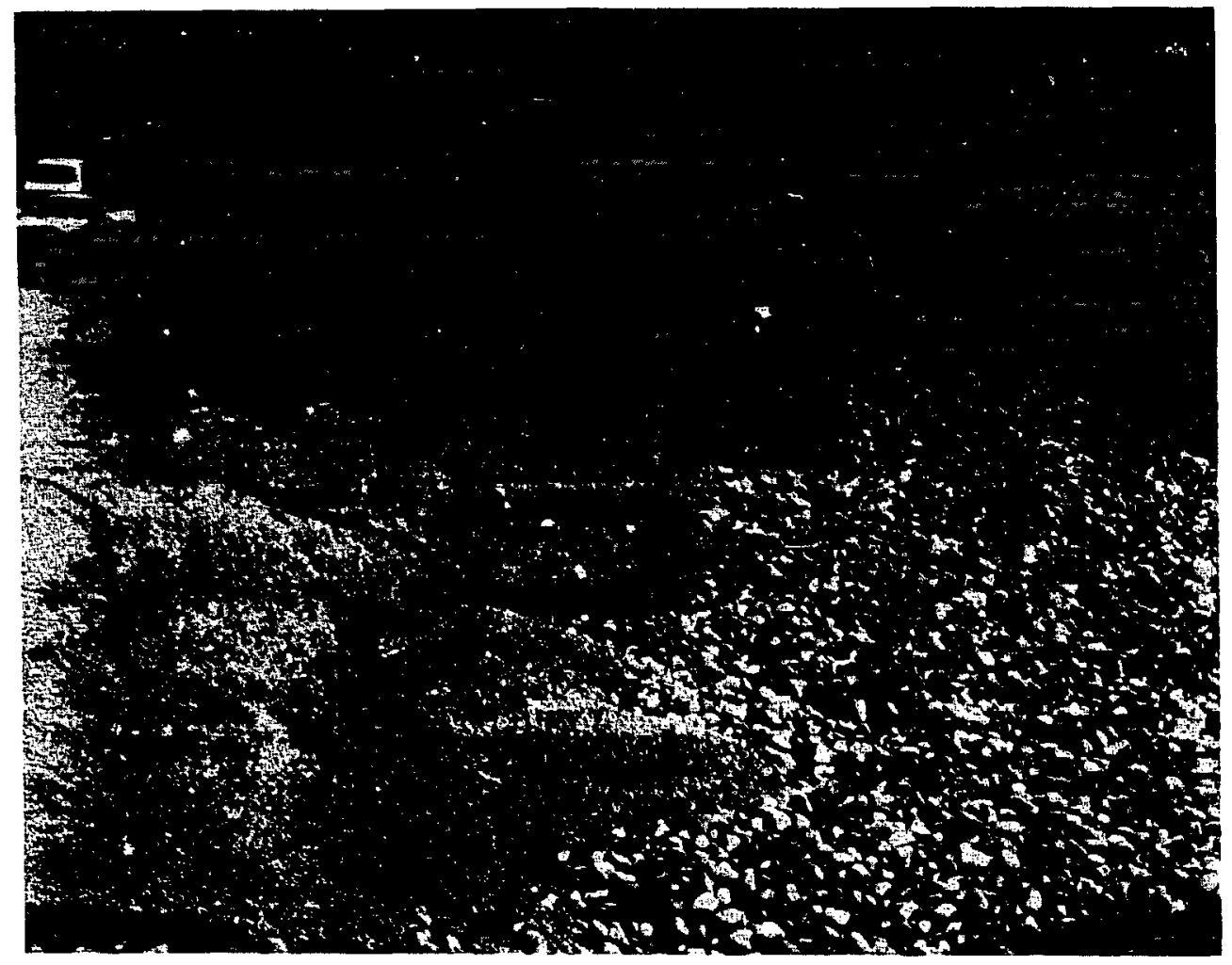

Fig. 24. Construction of layered cobble and gravel intrusion barrier cap design on Area B in 1982.

1982, plant cover did not become established until the spring of 1983 . The dominant plant species covering the site in 1983 was wheat (Triticum aestivum) whose seeds were present in the straw mulch (Fig. 25). In late 1983 and during the growing season of 1984 , perennial grasses and yellow sweet clover dominated the plant cover.

B. Results. In general, the cesium concentrations in plant samples collected during the growing season in 1983 (Table XII and Table C-I) averaged less than the 1-ppm background level. Only one sample [replicate four collected on $8 / 29 / 83$ from the soil/crushed tuff cap (Table C-I)] contained 


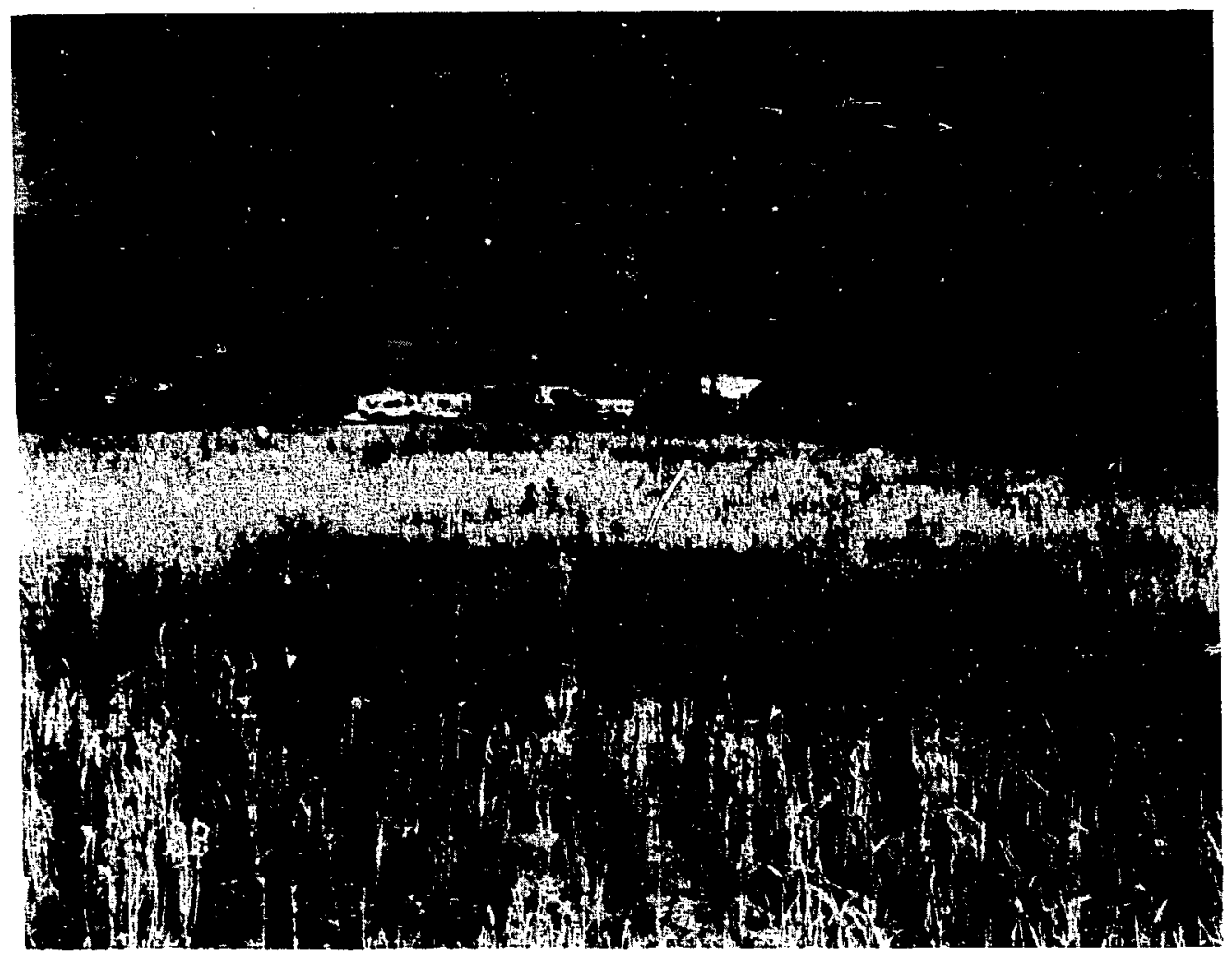

Fig. 25. Wheat cover on Area B biointrusion barrier study plots during 1983. Some grass cover did become established in 1983

and dominated the cover in 1984.

elevated cesium. Recall that the plant cover during the 1983 growing season was dominated by wheat. No data are available on the cesium content of the grass species (Table VII) that covered the site in 1984 .

The volumetric water content of topsoil (measured about $20 \mathrm{~cm}$ from the ground surface) and the soil under the two cap designs (measured $30 \mathrm{~cm}$ beneath the backfill-barrier interface) is presented in Figs. 26 and 27 along with daily precipitation and snow cover data in Fig. 28.

Topsoil moisture from late October 1982 to early May 1984 varied by a factor of seven and generally increased during the winter months and decreased during the summer months. Backfill moisture also followed that general 


\section{TABLE XII}

\section{AVERAGE CESIUM CONCENTRATIONS IN VEGETATION SAMPLES FROM CONVENTIONAL AND ROCK INTRUSION \\ BARRIER TRENCH CAP DESIGNS}

\section{Date}

June 21, 1983

July 21,1983

August 29, 1983

October 4, 1983

November 8, 1983
Trench Cap Design

$\begin{array}{ccc}\text { Soil-Cobble/Gravel } & & \text { Soil-Crushed Tuff } \\ 0.03(0.01)^{\mathrm{a}} & & 0.05(0.01) \\ 0.18(0.07) & & 0.24(0.18) \\ 0.27(0.03) & & 0.75(0.88) \\ 0.18(0.05) & & 0.17(0.09) \\ 0.21(0.05) & & 0.14(0.07)\end{array}$

${ }^{\mathrm{a}}$ Mean and standard deviation based on $\mathrm{n}=4$.

pattern, but with the exception of winter 1982-1983, the changes were undetectable to relatively small. The fact that relatively minor change in backfill moisture occurred during the summer months suggests that plant roots were not using water from this level and that the slight decline of soil moisture in this zone was likely due to unsaturated flow.

The most interesting feature of the soil moisture data from Area B is that snowmelt dominated over rainfall in recharging topsoil moisture and in contributing to percolation through both cap designs. For example, major increases in topsoil moisture during the winter of 1983-1984 (Fig. 26) were all correlated with periods of snow cover (Fig. 28) whereas changes in soil moisture due to rainfall were not observable with neutron moisture gauge data collected at l-month intervals. In fact, during the period from May 1 to November 1, 1983, when $18.5 \mathrm{~cm}$ of rain fell on Area B, topsoil moisture steadily declined from about $15-18 \%$ by volume to $7-10 \%$ by volume depending on the cap design. The decrease in soil moisture, as we have previously attributed to evapotranspiration, not only completely used that part of the $18.5 \mathrm{~cm}$-rainfall that infiltrated into the topsoil (i.e., all that was not runoff), but also used significant amounts of soil water in storage before 
May 1, 1983. As previously mentioned, major increases in topsoil moisture were sometimes followed by smaller increases in the soil underlying the trench caps (Fig. 17). This was especially apparent during the winter of 1982-1983 when a very sharp increase in backfill moisture occurred following snowmeltrelated rapid rise in topsoil moisture.

The data in Figs. 26 and 27 suggest that the topsoil/rock intrusion barrier design was also performing as a capillary barrier to percolating water, analogous to our observations from Caissons $C$ and D. For example, the water content of topsoil over the rock barrier generally averaged 2-5\% by volume higher than corresponding values for the tuff design (Fig. 26). Those differences suggest that percolation through the topsoil and into the rock was

(AREA B)

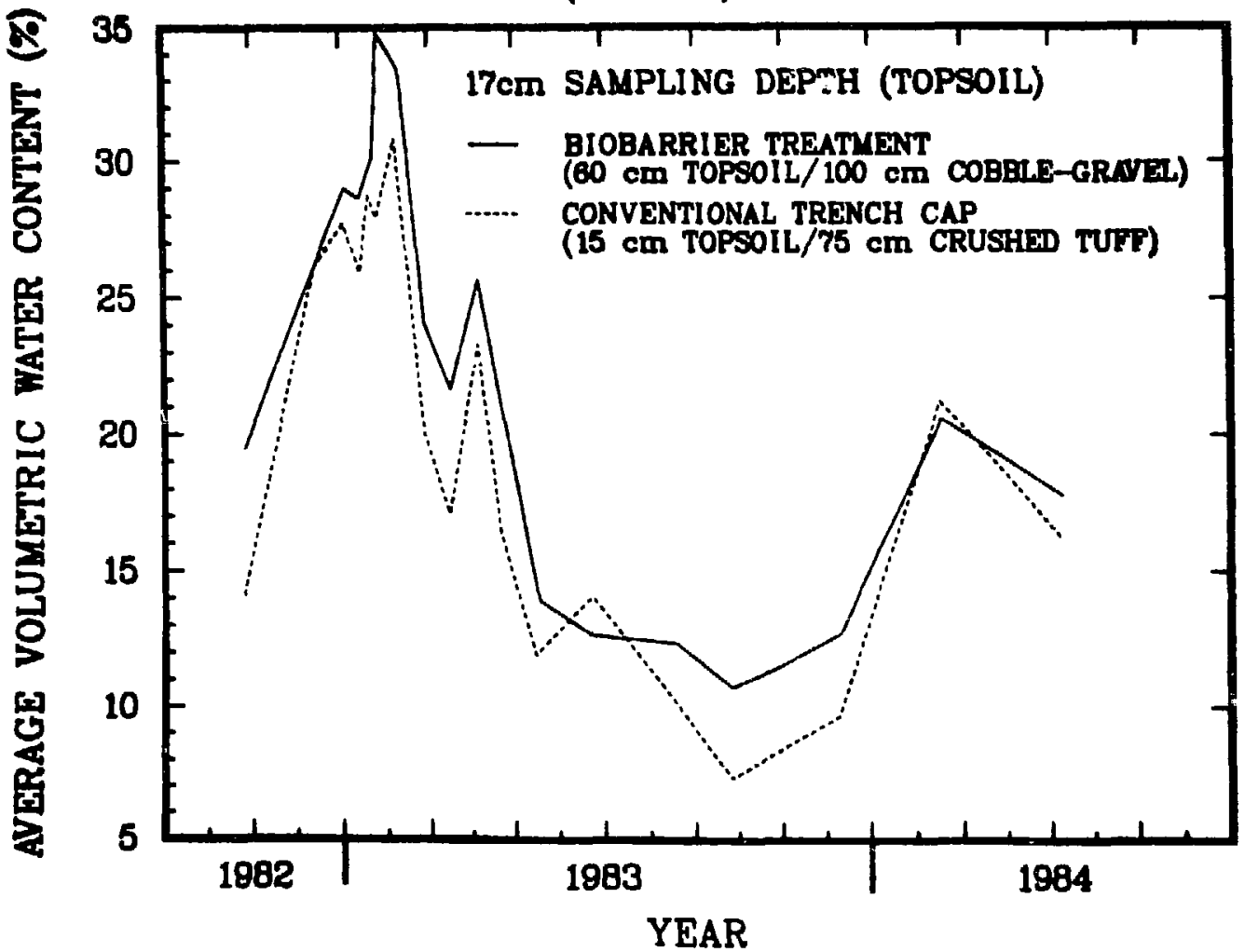

Fis. 26. Volumetric water content of the topsoil covering the biointrusion barriers used at Area $B$. 


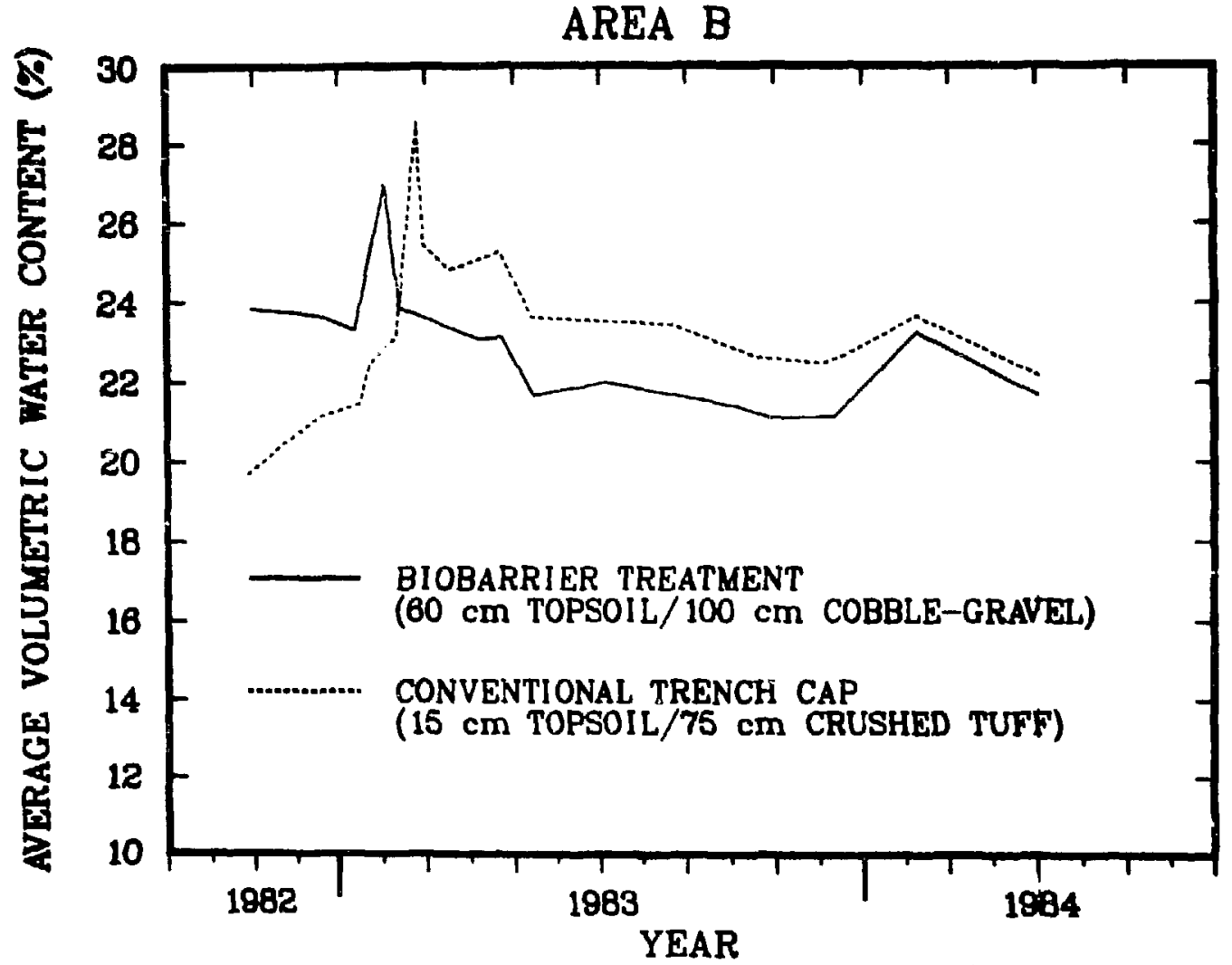

Fig. 27. Volumetric water content of backfill $30 \mathrm{~cm}$ under the biointrusion barriers used at Area $B$.

impeded to the extent of measurably increasing topsoil moisture. The greater the retention of water in the topsoil of the soil/rock cap design should be reflected in a lower backfill moisture content. The data for moisture content of backfill (Fig. 27) lend support to the latter statement.

The apparent lag time between the peak in backfill moisture for the two treatments during January and February 1983 likely reflects the differences in hydraulic conductivities of the barrier materials. Water percolating out of the topsoil very quickly passes through the l-m-thick rock barrier, whereas it moves relatively slowly through the tuff barrier. Consequently, percolation out of the topsoil is quickly reflected in the underlying backfill, whereas 


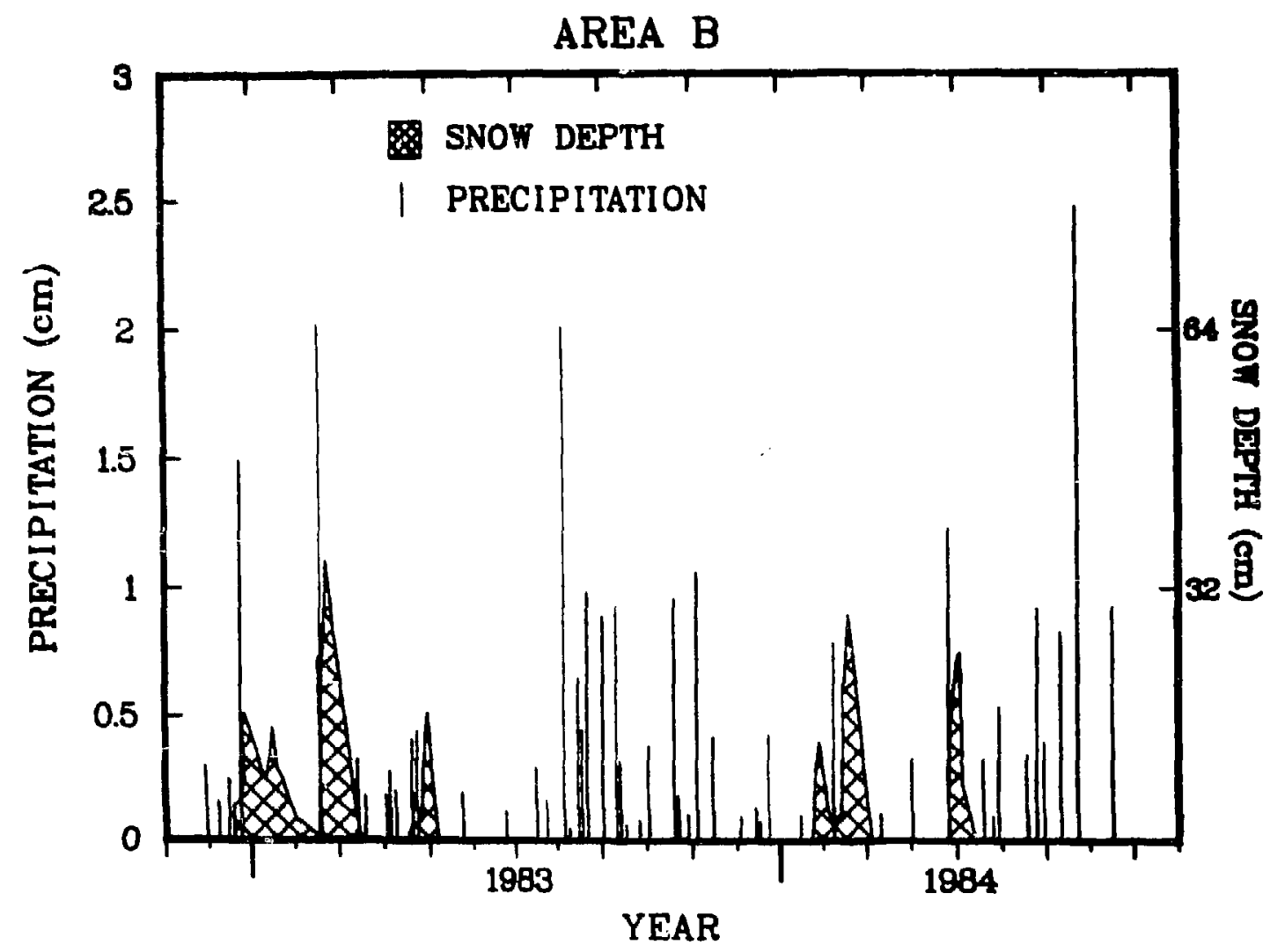

Fig. 28. Daily precipitation and snow cover during the biointrusion barrier study at Area B.

transit times th the backfill underlying the tuff barrier are relatively long. Based on the time between the two peaks, the difference in arrival time of percolating water to the backfill was about three weeks. The lack of differences between cap treatments in the arrival of percolating water during the winter of 1983-1984 is probably due to a lack of resolution of the peaks caused by infrequent moisture measurements.

Major results after 20 months of observation on the field-scale biointrusion barrier study at Area B can be summarized as follows:

o Both cap designs, over one growing season, prevented plant root intrusion to the simulated waste underlying the caps. 
- Snnwmeit dominated over rainfall in soil water recharge and led to all the observed incidents of percolation into the backfill underlying the cap designs.

- The soil/rock barrier system appeared to function as a capillary barrier that resuited in a lower inciciance of percolition and in lower so 1 moisture in the backfill than that for a soil/tuff design.

o Evapotranspiration effectively precluded percolation into the backfill during the sumner months regaidless of san design.

\section{DISCUSJION}

\subsection{Interp ration of Experimental Data}

The results of the small-scale biointrusion barrier study statistically demonstrated the advantage of using hentonite clay or rock, as opposed to crushed tuff, in designing a trench cap that limits plant root and burrowing animal intrusion. Furthermore, under the conditions of the experiment, a layered gravel and cobble barriar was considered superior to the bentonite clay and cobble barrier systems because of the relatively high probability of failure of the latter two systems (i.e., clay shririks and soll interpenetration intc cobble) within a short period of time (i.e., a few years).

The performance of the gravel/cobble intrusion barrier was significantly related to barrier and soil depth combinations, plant cover, and time within a particular year. A topsoil depth of $30 \mathrm{~cm}$ versus $60 \mathrm{~cm}$ did not appear to greatly affect the frequency of root intrusion through the gravel/cobble barrier (Table VI) although intermediate-scale and modeling studies revealed that the depth of topsoil was a critical factor in providing sufficient moisture storage capacity to control percolation. However, jntuitively, it 
would be expected that increasing the topsoi: depth would be important in reducing root intusion since root mass generally decreases dramatically [e.g., often expnnentially (Marshall, 1977)] with depth. In undisturbed soils, root distributions are often confined to the top meter of the soil profile. Data on rooting distributions in disturbed soils, including waste site trench caps, are limited even though such knowledge is necessary in designing optimum topsoil thickness to reduce root intrusion.

In contrast to the topsoil, increasing the gravel/cobble barrier depth reduced the frequenc: of root penetration with $90 \mathrm{~cm}$ of cobble covered with either $30 \mathrm{~cm}$ or $60 \mathrm{~cm}$ of gravel and provided the greatest protection against root intrusion (Table VI). Because the cobble (Fig. 5) is the primary component of the barrier preventing root penetration, the gravel serves primarily in reducing the rate of topsoil interpenetration into the cobble. Hence the thickness of materials used in the cap must be carefully evaluated to ensure long-term performance.

Ideally, an absolute filter of several layers of increasingly finer rock would be applied over the cobble to reduce significant soil interpenetration into the cobble over the life of the waste site. Physical examination of gravel/cobble cap designs, obtained by cutting the lysimeters open at the end of the small-scale experiment, revealed little movement of soil into the gravel and no movement of soil into the cobble (Fig. 5) even though $150 \mathrm{~cm}$ of vater was added to each lysimeter during the 1\%2-day study. While an absolute filter may control soil interpenetration, its use would likely eliminate the capillary barrier inherent in the design used in the lysimeter study.

The lysimeter study also revealed the importance of plant species in contributing to barrier failures (Table II). Early in the experiment, barley was associated with most of the barrier failures. As time progressed, the 
relative importance of the other species in contributing to the frequency to intrusions increased. Recall that the plant cover on the lysimeters was established from seed, so that root distributions during the study were rapidly changing. In the case of barley, an annual species, root growth by necessity must be rapid to fully exploit water and nutrient resources during its single growing season. In contrast, sweet clover (a biennial) and alfalfa (a perennial) have more than one season to fully develop a root system. The pattern in the data on frequency of penetration as a function of species and time (Table II) would suggest that rate of root development likely played some ro.e in contributing to the observed data by showing rapid penetration by barley and an increasing frequency of penetration by sweet clover and alfalfa with time.

Performance with time, of course, is a critical factor in judging the merit of a biointrusion barrier. The short duration of the lysimeter study leads to questions about the performance of the gravel/cobble barrier system after sufficient time (i.e., years) has passed to allow for full development of root systems of biennial and perennial species, including trees and shrubs, that may replace species planted on the site.

In addition to the question about performance of the gravel/cobble barrier with time, the lysimeter study did not address performance as influenced by experimental scale and subsidence, of the effects of the barrier on water balance. As mentioned previously, the intermediate and field-scale studies monitored performance of the gravei/cobble cap design with respect to scale and selected components of water bailance. The influence of subsidence on barrier performance was examined independently in another study (Abeele, 1984b). 
Both intermediate-scale studies, at Areas $G$ and Caissons $C$ and $D$, were initiated to determine the performance of soil/rock cap designs compared to a conventional soil/crushed tuff design with respect to plant root intrusion and effects on soil moisture beneath the cap. In addition, the evaluation of those factors was made for suboptimal topsoil depths (Area G) and for upper extreine moisture inputs, which were simulated using both natural and supplemental precipitations.

At Area G, where the design included a natural precipitation regime on a suboptimal (inadequate water storage capacity) topsoil depth, it was found that root intrusion had occurred through all of the cap designs (Appendix $A$, Table A-1). However, based on average concentrations over the entire study period, only plants growing on the soil/tuff cap design had concentrations elevated above background (Table VIII). In addition, average cesium concentrations in plants growing on the two gravel/cubble treatments were significantly $(p<0.05)$ lower, by factors of about three and eight, than corresponding values, or the soil/tuff design.

Similar results were obtained from the Caissons $C$ and $D$ study, where a 6C. cm topsoil depth over $100 \mathrm{~cm}$ of either crushed tuff or gravel/cobble was stressed by the addition of supplemental water to simulate upper extreme precipitation regimes for cos Alamos. Again, root intrusion was measurable through both barrier designs. However, cesium concentrations in plant samples from the rock barrier design averaged about one-third (significant at $p<0.05$ ) of those measured in samples frnm the tuff barrier design (Table XI).

Despite the attempt to stress the cap designs used in the Area $G$ and Caissons $C$ and $D$ studies, the gravel/cobble intrusion barrien appeared to offer some advantage over the conventional design in decreasing the frequency and levels of cesium appearing in plants growing on the plots. However, under 
those unusual conditions, root intrusion through the gravel/cobble barrier did occur, leading to the potential for some radionuclide transport to the surface of the trench cap.

The gravel/cobble cap design, under the conditions of Area $G$ and Caissons C and D studies, also leads to greater percolation of water into soil beneath the caps primarily due to loss of water storage capacity when replacing cap soil with rock. At Area G, the soil/tuff design had a total thickness of 115 $\mathrm{cm}$, all of which has significant water storage capacity. In contrast, only the $15 \mathrm{~cm}$ of topsoil over the rock intrusion barrier was capable of significant water storage. Based upon measurements (Nyhan, 1984), the $100 \mathrm{~cm}$ of gravel and cobble would store only about 4\% inoisture by volume at saturation. Given that crushed tuff reaches saturation at a volumetric water content of 36\% and that the Hackroy clay-loam topsoil reaches saturation at 40\%, then under static conditions, the soil/tuff cap design could store about $42 \mathrm{~cm}$ of water (or $30 \mathrm{~m}^{3}$ based on the $6-\times 13-\mathrm{m}$ plot dimension), while under the same conditions the soil/rock design could only store $10 \mathrm{~cm}\left(7.2 \mathrm{~m}^{3}\right)$ or about 75\% less than the soil/tuff design. Assuming that evapotranspiration was the sane from each plot, we would anticipate about four times more potential percolation from the soil/rock cap design.

Although we could not calculate the amount of percolation through the various cap treatments at Area B, results of the Caissons $C$ and $D$ study demonstrated that under conditions of very high water input, percolation from the soil/tuff cap design $(986 \mathrm{~L})$ was about 33\% less than frori the soil/rock cesign $(1474 \mathrm{~L})$. The soil/rock cap design (Fig. 14) with $60 \mathrm{~cm}$ of topsoil and $100 \mathrm{~cm}$ of gravel and cobble could store about $28 \mathrm{~cm}\left(2 \mathrm{~m}^{3}\right)$ of water while the 60-cm topsoil over $100 \mathrm{~cm}$ of tuff under the same conditions could store $60 \mathrm{~cm}$ $\left(4.2 \mathrm{~m}^{3}\right)$ of water. Therefore, based upon differences in water storage 
capacity alone, it would be assumed that potential percolation from the soil/rock design in Caisson D would be over two times greater than that from the soil/tuff design, given that evapotranspiration losses were equal. The measured differences of less than 50\% suggest that evapotranspiration water losses were not equivalent for the two designs.

Although the reasons for the relatively low percolation from the soil/rock cap design in the caisson study are not entirely clear, the observation that topsoil moisture above the rock barrier often averaged higher than that measured over the tuff barrier suggests that the soil/rock design was acting as a capillary barrier to percolation. Based on Eq. (1), where a change in volumetric water content of $1 \%$ is equivalent to a water depth of $0.6 \mathrm{~cm}$ for a 60-cm soil depth, it is apparent from Fig. 7 that the topsoil over the rock barier often was storing several centimeters more water than the topsoil over the tuff barrier stored. The enhanced water content of the soil over the rock barrier may have elicited a physical and/or physiological response from the plant cover leading to increased evapatranspiration.

Initial observations from the field-scale Area $B$ study are as yet inconclusive relative to comparative performance of the two cap designs in preventing biointrusion. Data from one growing season indicated that only one sample (from the soil/tuff cap design) had slightly elevated cesium concentrations suggestive of plant root intrusion throught the cap. With that exception, both designs had performed acceptably over one growing season in preventing root intrusion.

The relatively higher moisture content of topsoil over the rock barrier (compared to that over the tuff barrjer) was also observed at Area B. Furthermore, it appeared that the retention of water in the topsoil was having 
an effect on backfill moisture by maintaining it below that observed in the soil/tuff cap design.

An observation of great significance was that snowmelt dominated ove rainfall in soil water recharge and led to most occurrences of percolation at Areas $G$ and $B$ where natural precipitation was the only source of water. Smowmelt occurs slowly (compared to rainstorin events), produces little runoff on gentle slopes, and occurs during winter in the absence of significant plant transpiration and bare soil evaporation. As such, much of the melt water infiltrates the soil where it accumulates and moves into deeper zones. In contrast, water from rainfall events during the growing season is subject to runoff and evapotranspiration losses. Consequently, water that infiltrates into the soil is rapidly removed. It appears, therefore, that planning for maisture control in a waste site subject to snowmelt should consider a design that provides adequate water storage capacity in the trench cap so that snowmelt recharge of soil water during the winter can later be removed by evapotranspiration during the growing season.

Based on the results of the small, intermediate, and field-scale studies, with their attendant limitations, we conclude the following:

- The gravel/cobble intrusion barrier, although not $100 \%$ effective, did reduce uptake of a cesium tracer by plants by factors of about 3 to 8 over the conventional soil/tuff design at several different scales under suboptimum design configurations and upper extreme moisture inputs.

- Qualitative observations indicate that the gravel/cobble barrier design prevents burrowing through the trench cap by pocket gophers, although the long-term impact of such activities on soil movement into the gravel and on soil bulk density as it influences percolation is unknown. 
- Percolation of water through a soil/rock design may be greater than for a soil/tuff design under upper extreme moisture additions (Caissons $C$ and D) or when topsoil depths are suboptimal for storage of infiltration (Area G).

o Under field-scale conditions and natural precipitation at Los Alamos, the soil/rock design appears to impede percolation with a correspondirig reduction in the moisture content of backfill under the trench cap.

o Snowmelt, rather than rainfall, places more stress on the cap relative to percolation.

\subsection{Limitations/Research Needs}

One of the more serious limitations of the biointrusion studies is related to the time dimension. Virtually all of the data from a particular study (lysimeters) span as little as 6 months to a maximum of about 31 months (Area G). On time scales of 100-250 years, as are required for low-level waste isolation, those short-term observations and conclusions on biointrusion barrier performance are subject to several shortcomings, including the possible effects of

- plant succession, and particularly larger growth forms such as trees and shrubs;

o full root development of perennial species that may require several years;

o topsoil interpenetration into the rock barrier material; and

o subsidence of barrier integrity.

Because existing vegetation is destroyed during the construction of a low-level waste site, the final trench cap, upon closeout of the site, usually provides an excellent medium for the establishment of invader plant species because these species are adapted to growth in a highly disturbed soil. 
Despite vigorous attempts to establish a plant cover, natural seed sources present in the cap soil or seeds arriving from surrounding areas will become established on the site with time. Those plants may eventually dominate the plant cover given the lack of intensive management. For example, in 1983, Area B (which was closed in 1947) was covered by a mixture of trees, shrubs, forbs, and grasses, none of which had been seeded into the site. Rooting depths of the species growing on Area B could vary, based upon a survey of the literature (Foxx et al., 1984), from $5 \mathrm{~cm}$ to about $610 \mathrm{~cm}$ depending on species and physical characteristics of the site. Of course, our studies have not examined root intrusion by any of the larger growth forms, although alfalfa is typically one of the deepest rooting plants (Foxx et al., 1984), with records of root penetration to $4200 \mathrm{~cm}$. However, many species including alfalfa require several years to develop mature root systems so that observation periods of less than two years are not likely to be adequate to determine long-term barrier performance under field conditions.

The question of topsoil interpenetration into the rock barrier has not been addressed in our studies although it is relevant to considerations of long-term cap performance. Soil interpenetration into the cobble was not observed during the 6-month small-scale lysimeter study. However, over time scales of 100-200 years, those short-term observations have little meaning. Additionally, plant root and burrowing animal activities may enhance soil movement downward into the profile. However, the extent and importance of such activities to that process are unknown. We do know that the burrowing activities of pocket gophers (Thomomys bottae) can increase the maisture content of trench cap soil by encouraging infiltration of water into the soil while decreasing runoff and erosion (Hakonsan et a1., 1984). To what extent those effects would influence intrusion barrier performance is unknown. 
The effect of subsidence on barrier performance is especially important because virtually every low-level waste site has incurred or can be expected to incur subsidence as a consequence of decomposition of waste in the trench. A study initiated at the Los Alamos EETF was designed to address the question of gravel/cobble barrier performance under various degrees of subsidence (Abeele, 1984b). Technical problems in initiating the experiment delayed acquisition of data, thus precluding discussion of the results in this report. However, qualitative observations demonstrate that void spaces of $6.4 \mathrm{~m}^{3}$ and $11.5 \mathrm{~m}^{3}$, when created below ground, result in surface subsidence craters that clearly breach the 60-cm topsoil and 100-cm gravel/cobble trench cap. Visual inspection of craters produced by underground void spaces of $1.4 \mathrm{~m}^{3}$ and $3.4 \mathrm{~m}^{3}$ is not as conclusive, but may result in sufficiently small disruption of the rock barrier to require a minimum of remedial action. Of course, achieving subsidence craters within given dimensions would require special consideration in packaging and placement of the waste in the trench.

There are two questions related to plant cover that are of major significance relative to barrier performance in limiting biointrusion and percolation. The first relates to rooting distributions of the species that occupy the waste site and the second is related to the selection of an optimum species to maximize evapotranspiration while minimizing percolation, biointrusion, and erosion.

The difficulty in measuring root distributions with depth has led to a serious gap in knowledge that must be remedied in order to predict waste site perfarmance. A major requirement of most water balance models is knowledge of rooting distribution with depth in order to determine the depth from which water can be removed by transpiration. While plants with large transpiration capability and ceep roots are desirablu for moisture control, deep, 
penetrating roots provide the potential for transport of buried nuclides to the surface of the site.

Research needs to be conducted to allow for the selection of plant species or species mixes that have the following characteristics:

o They should maximize evapotranspiration.

o They should be shallow rooted.

- They should provide adequate erosion control.

- They should provide undesirable habitat for burrowing animals.

Ideally, selection of a plant cover with the attributes listed above, in combination with an optimal topsoil configuration (slope, soil type, soil depth), would serve as a primary componerit of the cap in controlling percolation and root penetration, while the underlying gravel/cobble material would function as a secondary barrier to these processes. The importance of carefully selecting the plant cover can be inferred from modeling studies (Nyhan and Lane, 1982; and Fig. 16), which show that annual percolation below the rooting zone of native grasses in arid sites is very low and is often far less than $10 \%$ of the long-term average annual precipitation. In contrast, evapotranspiration may account for at least $90 \%$ of the annual precipitation. Thus, only a slight increase in plant transpiration may completely preclude the occurrence of deep percolation. Studies are currently underway at Area $B$ to examine the effects of different plant covers on soil moisture in order to select optimum species or species mixes for meeting some of the plant cover requirements listed above (Rodgers et al., 1985).

\subsection{Implications for Waste Site Operations}

As stated in the beginning of this report, deciding whether a biointrusion barrier is necessary for trench closeout is not within the scope of this repurt. Assuming that site operations perceives that need, several questions 
must be addressed based on our present understanding relative to the use of soil-gravel/cobble cap designs.

1. Do sufficient supporting data exist to indicate that the soil/rock system reduces biointrusion and, possibly, percolation?

2. What is the optimum configuration for arid site conditions?

3. What are the costs of applying a soil/rock barrier design relative to conventional designs?

The answer to the first question is a qualified "yes" based on short-term data obtained under both intermediate- and rield-scale conditions and under both extreme and average precipitation regimes. Based on the experiments at Area $G$ and Caissons $C$ and $D$, where percolation was encouraged through intentional suboptimal design or enhanced precipitation, uptake of cesium was reduced by a factor of at least 2.5 and by as much as a factor of nearly 10 . As an added benefit, the soil/rock cap design appears to serve as a capillary barrier when adequate topsoil moisture storage capacity is provided for storing infiltration from natural storm events. However, extending those results to time scales of several years to decades is tenuous without further supporting data.

Clearly, the operator must recognize and account for the interactive nature of the physical, chemical, and biological processes that affect waste site integrity in order to vesign and model a disposal system that meets the performance objectives. The trench cap is a key component of the disposal system that can be designed to prevent unacceptable levels of erosion, percolation, and biological intrusion.

Technology currently exists [CREAMS (Nyhan and Land, 1984)] for setermining optimum cap soil configurations by combining physical features of $\therefore=3 p$ (i.e., soil type, soil thickness, surface slope, and management 
practice) with plant cover to minimize erosion and percolation. The modeling technology can be used at any site when certain parameters for the site are known (Nyhan and Lane, 1984).

A cap design incorporating an optimum mix of the physical and biological features described above would also serve to reduce plant root intrusion through the cap by confining water and roots to the cap. Ideally, cap soil depth would be sufficiently large to store all (at a specified probability level) precipitation infiltrating into the cap where it would then be available to complete loss by evapotranspiration.

It is especially important that the cap thickness be governed by the season during which soil moisture storage capacity is most needed. For example, our studies suggest that cap thickness should be based on snowmelt sources of infiltration. However, an optimum cap configuration may not be feasible due to the lack or scarcity of a "best" soil. Likewise, the lack of information on rooting distribution and water-use efficiency of species selected for revegetation limits our ability to select species that fully exploit the added moisture stored in the thicker cap profile. In either case, inadequate moisture storage capacity or less than optimum evapotranspiration losses of soil water can result in percolation below the root zone into deeper regions of the site. Unfortunately, using deeper-rooted plant species to revegetate the site presents poteritial problems with biointrusion and transport of waste to the surface of the site.

That, perhaps, is where the soil/rock intrusion barrier design may offer some advantage over the conventional soil cap design for arid sites. A relatively thin layer $(60-100 \mathrm{~cm})$ of topsoil over at least $100 \mathrm{~cm}$ of gravel and cobble not only reduced root intrusion, but at the same ijme appeared to retard percolation through the cap. Although many questions remain concerning 
the long-term field performance of the soil/rock cap design, the experience we have gained tnrough field studies and modeling is encouraging with respect to performance of this design for semiarid and arid sites.

Although we did not evaluate the soil/rock cap design for humid site conditions, the experimants in Caissons $C$ and $D$, which received large inputs of water approximating humid site conditions, suggest that failure of the soil/rock cap design can lead to greater percolation than would be experienced from a conventional soil cap design. However, topsoil depths of $60 \mathrm{~cm}$ used in the caisson experiments were not optimized for storage capacity for the upper extreme precipitation regime used in the experiment.

The cost of the materials for the soil/rock cap design at Area B is compared to that for the soil/tuff design in Table XIII. The estimates show that the soil/rock materials cost about four times the amount of the soil/tuff materials. Whether the potential benefit to be gained by using a rock intrusion barrier system is worthwhile must be judged in the context of the cost of future remedial action.

\section{TABLE XIII}

\section{COST OF APPLYING LAYERED ROCK BIOINTRUSION BARRIERS IN WASTE SITE COVERS IN 1983}

$\frac{\text { Barrier Type }}{\text { Cobble/gravel }}$

Crushed Tuff

\begin{tabular}{|c|c|}
\hline Configuration & \$/ha \\
\hline $\begin{array}{l}75 \mathrm{~cm} \text { cobble } \\
25 \mathrm{~cm} \text { gravel } \\
60 \mathrm{~cm} \text { topsoil }\end{array}$ & $\begin{array}{l}75 \mathrm{~K} \\
25 \mathrm{~K} \\
20 \mathrm{~K}\end{array}$ \\
\hline $\begin{array}{l}100 \mathrm{~cm} \text { tuff } \\
15 \mathrm{~cm} \text { topsoil }\end{array}$ & $\begin{array}{r}30 \mathrm{~K} \\
5 \mathrm{~K}\end{array}$ \\
\hline
\end{tabular}


Although cost of a layered rock intrusion barrier is relatively high, the cost relative to operation, closeout, and long-term management of the site would be minimal. A commercial operation charging $\$ 165 / \mathrm{m}^{3}\left(\$ 5 / \mathrm{ft}^{3}\right)$ to bury waste would expend roughly $\$ 0.67 / \mathrm{m}^{3}$ of waste to apply a 1 -m-thick gravel/cobble barrier based on the cost of applying this barrier to Area $B$ at Los Alamos.

\section{ACKNOWLEDGEMENTS}

I gratefully ackncisledge the many individuals who contributed to the completion of this work including K. V. Bostick, J. L. Martinez, E. M. Karlen, W. J. Herrera, G. Trujillo, J. W. Nyhan, G. L. DePoorter, B. A. Lauctes, M. T. Saladen, D. J. McInroy, T. Grieggs, E. Montoya, E. S. Gladney, H. Sowerwine, M. Muller, C. Reynolds, and J. G. Steger.

\section{REFEFIENCES}

Abaturov, B. D., The Role of Burrowing Animals in the Transport of Mineral Substances in the Soil," Pedobiologia 12, 261-256 (1972).

Abeele, W. V., "Future Credjble Precipitation Occurrences in Los Alamos, New Mexico," Los Alamos Scientific Laboratory report LA-8523-MS (1980).

Abeele, W. V., "Geotechnical Aspects of Hackroy Sandy Loam and Crushed Tuff," Los Alamos National Laboratory report LA-9916-MS (1984a).

Abeele, W. V., "Subsidence and Settlement and Their Effect on Shallow Land Burial," Los Alamos National Laboratory report LA-10261-MS (1984b), pp. 42.

Arthur, J. W. II $\bar{i}$, and 0. D. Markham, "Small Mammal Soil Burrowing as a Radionuclide Transport Vector at a Radioactive Waste Disposal Area in Southeastern Idaho," Juulnal of Environmental Quality $12(10), 117-122$; 1983 ).

Buechner, H. K., "Interrelationships Between the Pocket Gopher and Land Use," J. Mammal 23, $348(1: 42)$. 
Burton, F. G., D. A. Cataldo, J. F. Cline, and W. E. Skiens, "The Use of Controlled Release Herbicides in the Waste Burial Site," in "Proceedings of the 8 th International Controlled Release Symposium," Ft. Lauderdale, Florida, July 26-29, 1981 (1982).

Chaw, R. M., "The Impact of Small Mammals on Ecosystem Structure and Function," Populations of Small Mammals Under Natural Conditions, (Pymatuning Laboratory of Ecology, Special Publication No. 5, May 1976).

Chew, R. M., "Consumers as Regulators of Ecosystems: An Alternative to Energetics," Ohio Journal of Science 74, 359-370 (1974).

Cline, J. F., K. A. Gano, and L. E. Rogers, "Loose Rock as Biobarrıers in Sha? luw Land Burial," Health Physics 39, 497-504 (1980).

Connolly, R. A. and R. E. Landstrom, "Gopher Damage to Buried Cable Materials," Materials Research Society 9, 13 (1969).

DePoorter, G. L., "Arid Site Technology at the Los Alamos National Laboratory: Model Verification," ORNL/NRW-81/34 (Noyember 1981).

Dixon, W. J. and M. B. Brown, BMDP-Biomedical Computer Programs P-Series, (University of California, Los Angeles, California, 1979).

Dreicer, M., T. E. Hakonson, G. C. White, and F. W. Shicker, "Rainsplash as a Mechanism for Soil Contamination of Plant Surfaces," Health Physics 46, $177-188$ (1984).

Duguid, J. 0., "Assessment of DOE Low-Level Radioactive Solid Waste Disposal Storage Activities," Battelle Memorial Institute (1984), Columbus, Ohio (November 1977).

Eliison, L., "The Pocket Gopher in Relation to Soil Erosion in Mountain Ranges," Ecology 27, 101-114 (1946).

Federer, C. A., "Evapotranspiration (Literature Review, 1971-1974)," Reviews of Geophysics and Space Physics 13, 442-445 (1975).

Fe]thauser, M., and D. McInroy, "Mapping Pocket Gopher Burrow Systems with Expanding Polyurethane Foam," Journal of Wildlife Management 47 (1983).

Foxx, T. S., G. D. Tierney, and J. M. Williams, "Rooting Depth of Plants on Low-Level Waste Disposal Sites," Los Alamos National Laboratory report LA-10253-MS (1984).

Gladney, E. S., T. E. Hakonson, and M. M. Muller, "Cesium as an Activatible Tracer for Studying Biological Intrusion of Plant Roots into Waste Burial Sites," Journal of Radioanalytical and Nuclear Chemistry, 84(2): 423-429 $(1984)$.

Grant, W. E., "The Functional Role of Small Mammals in Grassland Ecosystems," Ph.D. Thesis, Colorado State University, Fort Collins, Colorado (1974).

Gunderson, H. L., Mammalogy (MicGraw-Hill, New York, 1976). 
Hakonson, T. E., and J L. Martinez, "Disturbance of a Low-Level Waste Site Trench rover by Pocket Gophers," Health Physics 42, 868-871 (1982a).

Hakonson, T. E., and J. W. Nyhan, "Ecological Relationships of Plutonium in Southwest Ecosystems," in "Transuranic Elements in the Environment, W. C. Hanson (Ed.), DOE/TIC 22800, US Department of Energy, NTIS, Springfield, Virginia, Pp. 403-419 (1980).

Hakonson, T.E., J. R. Cline, and W. H. Rickard, "Biological Intrusion Barriers for Large Volume Waste Disposal Sites," in "Proceedings Low-Level Disposal: Facility Design, Construction, and Operating Practices," NUREG/CP-0028, CONF/820911 Vol. 3, (US Nuclear Regulatory Commission, Washington, D.C., September 29-30, 1982 (1983).

Hakonson, T. E., L. J. Lane, J. G. Steger, and G. L. DePoorter, "Some Interactive Factors Affecting Trench Cover Integrity on Low-Level Waste Sites," in "Low-Level Waste Disposal-Site Characterization and Monitoring," M. G. Yalcintas (Ed.), NUREG/CP-0028, CONF-820674, Vol. 2, NTIS, Springfield, Virginia, Pp. 377-400 (1982).

Hakonson, T. E., G. C. White, E. S. Gladney, and M. M. Muller, "Preliminary Assessment of Geological Materials to Minimize Biological Intrusion of Low-Level Waste Trench Covers and Plans for the Future," ORNL/NFW-81/34 (1981), Pp. 337-346.

Hakonson, T. E., G. C. White, and G. L. DePoorter, "Field Evaluation of Geological Materials to Limit Biological Intrusion of Low-Level Waste Covers," in "Proceedings of the Waste Management 82-American Nuclear Society," (Tucson, Afizona, March 8-11, 1982b).

Hakonson, T.E., G. C. White, and E. M. Karlen, "Evaluation of Geologic Materials to Limit Biological Intrusion of Low-Level Waste Covers," in "Proceedings of the American Nuclear Society Topical Meeting on Treatment and Handling of Radioactive Wastes," (Richland, Washington, April 19-22, 1982c).

Hakocson, T. E., G. R. Foster, L. J. Lane, and J. W. Nyhan, "The Application of an Agricultural Water Balance and Erosion Model in Environmental Science - A User Perspective," Prediction of Nonpoint Source Pollution: Model Selection and Application, A. Giorgini (Ed.), Hydraulics and Systems Engineering report CE-HSE-83-18 (Purdue University, West Lafayette, Indiana, September 1984).

Hakonson, T. E. and K. V. Bostick, "The Availability of Environmental Radioactivity to Honey Bee Colonies at Los Alamos," Journal of Environmental Quality, 5: PP. 307-310, 1976.

Hanson, R. M. and M. J. Morris, "Movement of Rocks by Northern Pocket Gophers," Journal of Mammal, 49: pp. 391-399, 1968.

Hoover, E. F., "Pocket Gopher Damage on Ponderosa Pine Plantations in Southwestern Oregon," Journal of Wildlife Management, 34: pp. 345-352, 1971. 
Jacobs, D. G., J. S. Epler, and R. R. Rose, "Identification of Technical Problems Encountered in the Shallow Land Burial of Low-Level Radioactive Wastes," Oak Ridge National Laboratory/SUB-80/136/1, Oak Ridge, Tennessee, March, 1980.

King, C. M., "Radionuclide Migration Mociel for Buried Waste at Savannah River Plant," pp. 155-170, Waste Management 82, University of Arızona Press, Tucson, Arizona, March 1982.

Klepper, E. L., L. E. Rogers, J. D. Hedlund, and R. G. Schreckhise, "Radioactivity Associated with Biota and Soils of the 216-A-24 Crib," Pacific Northwest Laboratory report, PNL-1948-UC-70, 1979.

Knisel, H. G. Jr., (ed.), CREAMS: A Field Scale Model For Chemicals, Runoff, and Erosion From Agricultural Management Systems, U. S. Department of Agriculture-Conservation Research Report No. 26, U. 5. Department of Agriculture, Science and Education Administration, pp. 640, May 1980.

Langer, W., An Encyclopedia of World History, (Houghton Mifflin Co., Boston, Massachusetts, 1968) pp. 1504.

McKenzie, D. H., L. L. Cadwell, L. E. Eberhardt, W. E. Kennedy, Jr., R. A. Peloquin, and M. A. Simmons, "Relevance of Biotic Pathways to the Long-Term Regulation of Nuclear Waste Disposal: Topical Report on Reference Eastern Humid Low-Level Sites," NUREG/CR-2675, Vol. 3, US Nuclear Regulatory Commission, Washington, D. C., 1984

Mckenzie, D. H., L. L. Cadwell, L. E. Eberhardt, W. E. Kennedy, R. A. Peloquin, and M. A. Simmon, "Relevance of Biotic Pathways to the Long-Term Regulation of Nuclear Waste Disposal," NUREG/CR-2675, PNL-4241, Vol. 4, US Nuclear Regulatory Commission, Washington, D. C., 1982.

Marshall, J. K. (ed.), "The Belowground Ecosystem, A Synthes is of Plant-Associated Processes," Range Science Department 5cience Series No. 26, Colorado State University, Foıt Collins, Colorado, pp. 351, 1977.

Maslov, V.I., K. I. Maslova, and I. N. Verkhouskaya, "Characteristics of tine Radioecological Groups of Animals and Birds of Biogeoceonosis With High Natural Radioactivity," Radioecological Concentration Process, (Pergamon Press, London, 1967).

Nie, N. H., C. H. Hull, J. G. Jenkins, K. Steinbrennon, and D. H. Bent, SPSS Statistical Package For The Social Sciences, (2nd edition), (McGraw-Hill, New York, 1975).

Nyhan, J. W., W. V. Abeele, E. J. Cokal, B. A. Perkins, and L. J. Lane, "Technology Deveiopment for the Design of Shallow Land Burial Facilities at Arid Sites," Los Alamos National Laboratory document LA-UR-84-2893, (1984).

Nyhan, J. W., L. W. Hacker, T. E. Calhoun, and D. L. Young, "Soil Survey of Los Alamos County, New Mexico," Los Alamos Scientific Laboratory report, LA-6779-MS (June, 1978), PP. 102. 
Wyhan, J. W. and L. J. Lane, "Use of a State of the Art Model in Generic Designs of Shallow Land Repositories For Low-Level Haste," Waste Management 1982, R. G. Post (ed.), University of Arizona Press, Tucson, Arizona, pp. 235-244, 1982.

Nyhan, J. W. and L. J. Lane, "Erosion Control Techrology: A User's Guide to the Use of the Univeral Soil Loss Equation at Waste Burial Facilities," Los Alamos National Laboratory report LA-10262-MS, (1984).

O'Farrell, T. P. and R. O. Gilbert, "Transport of Radioactive Materials by Jack Rabbits on the Hanford Reservation," Health Physics 29, 9-15 (1975).

Pertusa, M., "Materials to Line or to Cap Disposal Pits for Low-Level Radioactive Nastes," Geotechnical Engineering report GEBO-1, Department of Civil Engineering, University of Texas, Austin, Texas, 1980.

Rodgers. J. C., F. J. Barnes, T. S. Foxx, and G. D. Tierney, "Maintenance Free Vegetacive Systems For Landfill Covers," Los Alamos National Laboratory document LA-UR-84-307 (April 1985).

Saxton, K. E., "Evapotranspiration," Hydrologic Modeling of Small Watersheds, C. T. Haan, H. P. Johnson, and D. L. Brakeniek (Eds.), (The American Society of Agricultural Engineers, 2950 Niles Road, St. Joseph, Michigan, 1982), pp. 229-273.

Thorpe, J., "Effects of Certain Animals That Live in Soils," Scientific Monthly, 68, 180-191 (1949).

US Nuclear Regulatory Commission, Draft Environmental Impact Statement on 1OCFR Part 6l, "Licensing For Land Disposal of Radioactive Waste," NUREG-0782, US Nuclear Regulatory Commission, Washington, D. C., 1981.

Watters, R. L., D. N. Edgington, T. E. Hakonson, W. C. Hanson, M. H. Smith, F. W. Whicker, and R. E. Wildung, "Synthesis of Research Literature," Transuranic Elements in the Environment, W. C. Hanson (ed.), DOE/TIC 22800, US Department of Energy, NTIS, Springfield, Virg.inia, pp. 1-44, 1980.

White, G. C., T. E. Hakonson, and A. J. Ahlquist, "Factors Affecting Radonuclide Availability to Vegetables Grown at Los Alamos," Journal of Environmental Quality, (Madison, Wisconsin, Vol. 10, 1981) pp. 294-299.

Winsor, T. F. and F. W. Whicker, "Pocket Gophers and Redistribution of Plutonium in Soil," Health Physics 39, 257-262 (1980). 
APPENDIY A 
TABLE A-I

CESIUM CONCENTRATIONS (PPM) IN INDIVIDUAL DLANT SAMPLES FROM THE 15 CM TOPSOIL OVER 30 CM GRAVEL OVER 70 CM COBBLE BIOINTRUSION BARRIER TRENCH CAP DESIGN AT AREA G

Sample Number

\section{Date}

June 22, 1982

July 2,1982

July 12,1982

September 15, 1982

September 27, 1982

October 8, 1982

October 18, 1982

November 1, 1982

April 14, 1983

June 8,1983

July 27, 1983

Augusi 29. 1983

October 4, 1983

November 8,1983

\begin{tabular}{|c|c|c|c|c|}
\hline 1 & 2 & 3 & 4 & 5 \\
\hline 0.2 & 0.1 & 0.2 & 0.3 & $0 . !$ \\
\hline 0.1 & 0.2 & 0.2 & 0.1 & 0.1 \\
\hline 0.2 & 0.3 & 0.2 & 0.3 & 0.2 \\
\hline 0.2 & 0.1 & 0.2 & 0.1 & 0.2 \\
\hline 0.1 & 0.1 & 0.2 & 0.1 & 0.02 \\
\hline 096 & 0.12 & 0.25 & 0.11 & 0.05 \\
\hline 0.19 & 0.16 & 0.10 & 0.07 & 0.08 \\
\hline 0.09 & 0.07 & 0.09 & 0.08 & 0.13 \\
\hline 0.45 & 0.74 & 0.58 & 0.48 & 1.0 \\
\hline 0.06 & 0.16 & 0.16 & 0.20 & 0.09 \\
\hline 0.09 & 0.21 & 0.11 & 0.21 & 0.12 \\
\hline 0.11 & 0.22 & 0.08 & 0.07 & 0.07 \\
\hline 0.20 & 0.23 & 0.20 & 0.12 & 0.16 \\
\hline $9.3^{a}$ & 1.0 & 0.28 & 0.23 & 0.22 \\
\hline
\end{tabular}

'Highlighted value exceeds background concentration of $\leq 1 \mathrm{ppm}$. 
TABLE A-II

\section{CESIUM CONCENTRATIONS (PPM) IN INDIVIDUAL PLANT SAMPLES FROM THE $15 \mathrm{CM}$ TOPSOIL OVER $100 \mathrm{CM}$ CRUSHED TUFF BIOINTRUSION BARRIER TRENCH CAP DESIGN AT AREA G}

Sample Number

Date

June 22. 1982

July 2.1982

July 12. 1982

September 15, 1982

September 27. 1982

October 8. 1982

October 18.1982

November 1. 1982

April 14. 1983

June 8.1983

July 27.1983

August 29.1983

October 4.1983

November 8. 1983

\begin{tabular}{|c|c|c|c|c|}
\hline 1 & 2 & 3 & 4 & 5 \\
\hline 0.3 & 0.3 & 0.4 & 0.0 & 0.2 \\
\hline 1.0 & 0.1 & 0.5 & 4.4 & 10 \\
\hline 0.3 & 1.0 & 1.0 & 0.4 & 0.2 \\
\hline 0.3 & 0.1 & 0.1 & 0.3 & 0.2 \\
\hline 0.01 & 0.1 & 0.8 & 0.9 & 0.11 \\
\hline 0.13 & 0.18 & 0.15 & 0.06 & 0.18 \\
\hline 0.11 & 0.14 & 0.07 & 15 & $0.0^{7}$ \\
\hline 0.23 & 0.15 & 0.19 & 0.2 & 0.11 \\
\hline 0.64 & 0.49 & 0.72 & 0.47 & 0.72 \\
\hline 0.12 & 0.08 & 0.11 & 0.28 & 025 \\
\hline 0.23 & 0.37 & 0.68 & 0.09 & 0.09 \\
\hline 0.07 & $26^{2}$ & 23 & 3.0 & 0.38 \\
\hline 0.42 & 0.34 & 0.25 & 0.27 & 0.18 \\
\hline 0.33 & 2.5 & 1.5 & 83 & 2.5 \\
\hline
\end{tabular}

${ }^{2}$ Highlighted values exceed background concentrations of $\leq 1 \mathrm{ppm}$. 
TABLE A-III

\section{CESIUM CONCENTRATIONS (PPM) IN INDIVIDUAL PLANT SAMPLES \\ FROM THE 15 CM TOPSOIL OVER 100 CM COBBLE BIOINTRUSION BARRIER TRENCH CAP DESIGN AT AREA G}

Sample Number

\begin{tabular}{|c|c|c|c|c|c|}
\hline Date & 1 & 2 & 3 & 4 & 5 \\
\hline June 22, 1982 & 1.1 & 0.4 & 0.4 & 0.7 & 0.3 \\
\hline July 2, 1982 & 0.3 & 0.3 & 0.2 & 0.5 & 0.3 \\
\hline July 12,1982 & 1.0 & 0.4 & 0.4 & 1.0 & 0.3 \\
\hline September 15,1982 & 0.2 & 0.2 & 0.1 & 2.4 & 0.3 \\
\hline September 27,1982 & 0.11 & 0.1 & 0.2 & $0 . ?$ & 0.7 \\
\hline October 8.1982 & 0.11 & 0.12 & 0.09 & 0.08 & 0.4 \\
\hline October 18,1982 & 0.11 & 0.09 & 0.09 & 0.08 & 0.1 \\
\hline November 1, 1982 & 0.13 & 0.2 & 0.13 & 0.4 & 0.16 \\
\hline April 14. 1983 & 0.58 & 0.92 & 0.55 & 0.78 & 0.57 \\
\hline June 8,1983 & 0.09 & 0.11 & 0.16 & 0.17 & 0.13 \\
\hline July 27,1983 & 0.2 & 0.3 & 0.38 & 0.17 & 0.20 \\
\hline August 29,1983 & 0.07 & 0.12 & 0.1 & 0.12 & 0.29 \\
\hline October 4,1983 & 0.14 & 0.12 & 0.16 & 0.16 & 0.13 \\
\hline November 8,1983 & 0.18 & 0.15 & 0.11 & 0.11 & 0.17 \\
\hline
\end{tabular}

'Highlighted value exceeds background concentration of $\leq 1 \mathrm{ppm}$. 
TABLE A-IV

CESIUM CONCENTRATIONS (PPM) IN INDIVIDUAL PLANT SAMPLES FROM THE 15 CM TOPSOIL OVER 15 CM GRAVEL OVER 85 CM COBBLE BIOINTRUSION BARRIER TRENCH CAP DESIGN AT AREA G

Sample Number

Date

June 22, 1982

July 2,1982

July 12,1982

Seplember 15, 1982

September 27, 1982

Oclober 8,1982

October 18,1982

November 1, 1982

April 14, 1983

June 6,1983

july 27,1983

August 29, 1983

October 4, 1983

November 8, 1983

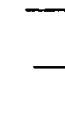

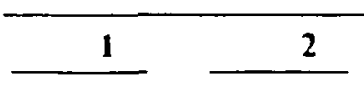

$1.8^{\mathrm{A}}$

2.0

3.0

0.3

0.5

0.12

0.23

0.18

0.8

0.19

0.4

0.11

0.29

0.18
1.0

1.2

0.4

0.2

0.1

0.1

0.41

0.49

0.82

0.31

0.15

0.33

0.38

0.51

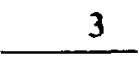

0.3

. 2.0

18

0.1

0.2

0.09

0.11

0.003

0.96

0.54

0.14

0.55

0.08

0.38

${ }^{a}$ Highlighted values exceed background concentrations of $\leq 1 \mathrm{ppm}$. 
TABLE B-I

\section{CESIUM CONCENTRATIONS IN VEGETATION SAMPLES FROM \\ CAISSON C (TOPSOIL-CRUSHED TUFF) \\ AND CAISSON D (TOPSOIL-GRAVEL/COBBLE) \\ TRENCH COVER INTRUSION BARRIER DESIGNS}

\begin{tabular}{l} 
Sample \\
Date \\
\hline
\end{tabular}

June 22, 1982

July 2.1982

July 12,1982

July 22, 1982

August 2. 1982

August 12, 1982

August 23, 1982

September 2, 198:

Septemioer 13,1982

September 24, 1982

October 5, 1982

October 15, 1982

October 25, 1982

April 14, 1983

June 8, 1983

July 27, 1983

August 29.1983

October 4, 1983

November 8, 1983
Caisson C

\begin{tabular}{|c|c|c|c|c|c|c|c|}
\hline \multicolumn{4}{|c|}{ Sample Number } & \multicolumn{4}{|c|}{ Sample Number } \\
\hline 1 & 2 & 3 & 4 & 1 & 2 & 3 & 4 \\
\hline 0.3 & 0.1 & 0.2 & 0.2 & 0.2 & 0.3 & 0.3 & 1.0 \\
\hline 0.1 & 0.1 & 0.1 & 0.1 & 0.1 & 0.1 & 0.1 & 0.1 \\
\hline 0.1 & 0.03 & 0.03 & 0.1 & 0.1 & 0.1 & 0.03 & 0.01 \\
\hline 0.2 & 0.1 & 0.2 & 0.1 & 0.2 & 0.1 & 0.4 & 0.1 \\
\hline 0.2 & 0.1 & 0.2 & 0.2 & 0.3 & 0.2 & 1.8 & 0.3 \\
\hline 0.2 & 0.1 & 0.1 & 9.8 & 0.2 & 0.1 & 47 & 0.5 \\
\hline 0.89 & 0.6 & 1.3 & 1:4 & $f: 5$ & 5.3 & 4.1 & 4.1 \\
\hline $48^{2}$ & 0.3 & 0.2 & 0.5 & 0.3 & 0.3 & 3.7 & 0.2 \\
\hline 0.13 & 1.4 & 0.1 & 0.2 & 0.4 & 0.2 & 2.3 & 0.9 \\
\hline 0.91 & 36 & 0.1 & 50 & 0.2 & 0.1 & $100^{\circ}$ & 0.2 \\
\hline 370 & 43 & 81 & 380 & 0.2 & 0.03 & 450 & 70 \\
\hline 350 & 0.3 & 0.1 & 0.2 & 0.2 & 110 & 30 & 30 \\
\hline 270 & 1.0 & 4.9 & 200 & 0.1 & 0.05 & 9.0 & 0.4 \\
\hline 110 & 2.1 & 1.9 & -44 & 0.3 & 0.3 & 0.3 & 0.6 \\
\hline 70 & 3.2 & 5.2 & 49 & 0.2 & 0.1 & 0.3 & 0.1 \\
\hline 1.6 & 0.7 & 0.5 & 0.5 & 0.6 & 0.4 & 0.5 & 0.7 \\
\hline 0.1 & 0.06 & 0.1 & 0.1 & 0.1 & 0.1 & 0.1 & 0.1 \\
\hline 0.5 & 0.6 & 1.3 & 0.9 & 0.5 & 1.9 & 0.6 & 0.9 \\
\hline 0.4 & 0.7 & 0.3 & 0.7 & 2.3 & 1.6 & 1.9 & 0.8 \\
\hline
\end{tabular}

${ }^{2}$ Highlighted values exceed background concentrations of $\leq 1 \mathrm{ppm}$. 
TABLE B-II

\section{PRECIPITATION FREQUENCY ESTIMATES FOR LOS ALAMOS, NEW MEXICO $\left(106^{\circ} 19^{\prime} W, 35^{\circ} 2^{\prime} \mathrm{N}\right.$, Elevation $\left.=7410 \mathrm{ft}\right)$ \\ FROM PRECIPITATION FREQUENCY ATLAS, "NOAA Atlas-2" (Miller et al. 1973)"}

\begin{tabular}{|c|c|c|c|c|c|c|c|c|}
\hline \multirow{2}{*}{$\begin{array}{l}\text { Return } \\
\text { Period } \\
\text { Tr } \\
\text { (years) } \\
\end{array}$} & \multicolumn{8}{|c|}{$\begin{array}{l}\text { Estimated Rainfall Depths in Inches for the } \\
\text { Given Time Period and the Given Return Period }\end{array}$} \\
\hline & $\begin{array}{c}15-\min \\
P_{13} \\
\end{array}$ & $\begin{array}{c}\text { 30-min } \\
P_{.0}\end{array}$ & $\begin{array}{c}\text { 60-min } \\
P_{60} \\
\end{array}$ & $\begin{array}{c}2-\mathrm{hr} \\
\mathrm{P}_{2} \\
\end{array}$ & $\begin{array}{c}\text { 3-hr } \\
\mathbf{P}_{\mathbf{3}} \\
\end{array}$ & $\begin{array}{c}\text { 6-hr } \\
P_{6} \\
\end{array}$ & $\begin{array}{c}24-h r \\
P_{24}\end{array}$ & $\begin{array}{c}\text { Annual } \\
\mathbf{P}_{A} \\
\end{array}$ \\
\hline 2 & 0.56 & 0.77 & 0.98 & 1.11 & 1.20 & 1.36 & 1.76 & 17.99 \\
\hline 5 & 0.72 & 1.00 & 1.26 & 1.42 & 1.53 & 1.74 & 2.32 & 24.06 \\
\hline 10 & 0.82 & 1.13 & 1.43 & 1.62 & 1.75 & 2.00 & 2.67 & 25.79 \\
\hline 25 & 0.95 & 1.31 & 1.66 & 1.89 & 2.04 & 2.32 & 3.14 & $27.9^{r}$ \\
\hline 50 & 1.07 & 1.49 & 1.88 & 2.13 & 2.30 & 2.61 & 3.57 & $29.0^{c}$ \\
\hline 100 & 1.19 & 1.64 & 2.08 & 2.36 & 2.55 & 2.90 & 4.00 & 30.24 \\
\hline
\end{tabular}

"Source: Miller, J. F., R. H. Frederick, and R. J. Tracey, NOAA Atlas-2, "Precipitation Frequency Atlas of the Westcrn United States, Volume IV-New Mexico," US Department of Commerce, NOAA, National Weather Service, Silver Spring, Maryland (1973).

"Source: Abeele, W. V., M. L. Wheeler, and B. W. Burton, "Geohydrology of Bandelier Tuff," Los Alamos National Laboratory report LA-8962-MS (1982).

'Interpolated values. 
APPENDIX $B$ 
APPENDIX C 